Florida International University FIU Digital Commons

2012

\title{
Herbivore and Nutrient Impact on Primary Producer Assemblages in a Tropical Marine Environment
}

Elizabeth Lacey

Florida International University, elacey@fiu.edu

DOI: $10.25148 /$ etd.FI12080701

Follow this and additional works at: https://digitalcommons.fiu.edu/etd

\section{Recommended Citation}

Lacey, Elizabeth, "Herbivore and Nutrient Impact on Primary Producer Assemblages in a Tropical Marine Environment" (2012). FIU Electronic Theses and Dissertations. 694.

https://digitalcommons.fiu.edu/etd/694 


\section{FLORIDA INTERNATIONAL UNIVERSITY}

Miami, Florida

\section{HERBIVORE AND NUTRIENT IMPACT ON PRIMARY PRODUCER} ASSEMBLAGES IN A TROPICAL MARINE ENVIRONMENT

A dissertation submitted in partial fulfillment of

the requirements for the degree of

DOCTOR OF PHILOSOPHY

in

BIOLOGY

by

Elizabeth Anne Lacey 
To: Dean Kenneth G. Furton

College of Arts and Sciences

This dissertation, written by Elizabeth Anne Lacey, and entitled Herbivore and Nutrient Impact on Primary Producer Assemblages in a Tropical Marine Environment, having been approved in respect to style and intellectual content, is referred to you for judgment.

We have read this dissertation and recommend that it be approved.

Deron Burkepile

Jennifer Rehage

James Heffernan

James Fourqurean, Co-Major Professor

Ligia Collado-Vides, Co-Major Professor

Date of Defense: June 22, 2012

The dissertation of Elizabeth Anne Lacey is approved.

\begin{tabular}{r}
\hline $\begin{array}{c}\text { Dean Kenneth G. Furton } \\
\text { College of Arts and Sciences }\end{array}$ \\
\hline Dean Lakshmi N. Reddi \\
University Graduate School
\end{tabular}

Florida International University, 2012 


\section{ACKNOWLEDGMENTS}

This dissertation was greatly improved through the dedication of co-major advisors: Dr. James Fourqurean and Dr. Ligia Collado-Vides and the committee: Dr. Deron Burkepile, Dr. James Heffernan and Dr. Jennifer Rehage. Funding was provided by the University Graduate School Doctoral Evidence Acquisition and Teaching Assistant Fellowships, Latin American and Caribbean Center Tinker Field Grant, Professional Association of Diving Instructors, International Phycological Society and Phycological Society of America. Sea urchin settlement racks were provided by Dr. Margaret Miller and isotopic analysis was completed by Dr. David Baker. Logistical and fieldwork support were supplied by Centro Ecológico Akumal, Universidad Autonóma de México and many volunteers. 
ABSTRACT OF THE DISSERTATION

HERBIVORE AND NUTRIENT IMPACT ON PRIMARY PRODUCER

ASSEMBLAGES IN A TROPICAL MARINE ENVIRONMENT

by

Elizabeth Anne Lacey

Florida International University, 2012

Miami, Florida

Professor James Fourqurean, Co-Major Professor

Professor Ligia Collado-Vides, Co-Major Professor

Globally, human populations are increasing and coastal ecosystems are becoming increasingly impacted by anthropogenic stressors. As eutrophication and exploitation of coastal resources increases, primary producer response to these drivers becomes a key indicator of ecosystem stability. Despite the importance of monitoring primary producers such as seagrasses and macroalgae, detailed studies on the response of these benthic habitat components to drivers remain relatively sparse.

Utilizing a multi-faceted examination of turtle-seagrass and sea urchinmacroalgae consumer and nutrient dynamics, I elucidate the impact of these drivers in Akumal, Quintana Roo, Mexico. In Yal Ku Lagoon, macroalgae bioindicators signified high nutrient availability, which is important for further studies, but did not consistently follow published trends reflecting decreased $\delta^{15} \mathrm{~N}$ content with distance from suspected source. In Akumal Bay, eutrophication and grazing by turtles and fishes combine to structure patches within the seagrass beds. Grazed seagrass patches had higher structural complexity and productivity than patches continually grazed by turtles and fishes. 
Results from this study indicate that patch abandonment may follow giving-up density theory, the first to be recorded in the marine environment. As Diadema antillarum populations recover after their massive mortality thirty years ago, the role these echinoids will have in reducing macroalgae cover and altering ecosystem state remains to be clear. Although Diadema antillarum densities within the coral reef ecosystem were comparable to other regions within the Caribbean, the echinoid population in Akumal Bay was an insufficient driver to prevent dominance of a turf-algal-sediment (TAS) state. After a four year study, declining coral cover coupled with increased algal cover suggests that the TAS-dominated state is likely to persist over time despite echinoid recovery. Studies on macroalgal diversity and nutrients within this same region of echinoids indicated diversity and nutrient content of macroalgae increased, which may further increase the persistence of the algal-dominated state.

This study provides valuable insight into the variable effects of herbivores and nutrients on primary producers within a tropical coastal ecosystem. Results from this work challenge many of the currently accepted theories on primary producer response to nutrients and herbivory while providing a framework for further studies into these dynamics. 


\section{TABLE OF CONTENTS}

CHAPTER

PAGE

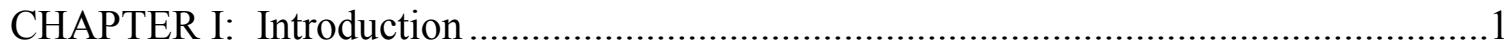

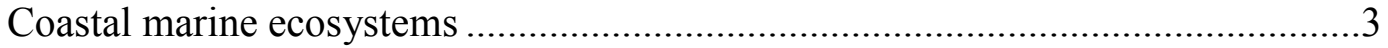

CHAPTER II: Challenges in using marine macroalgae tissue chemistry for assessing nutrient pollution in the Mexican Caribbean ................................................................

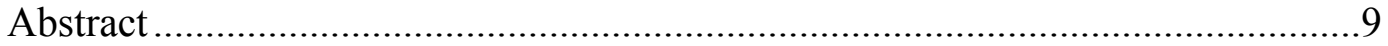

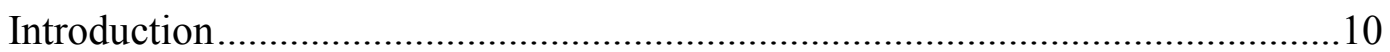

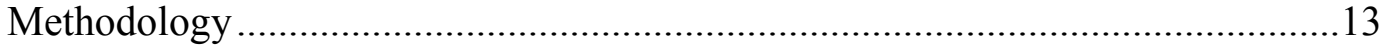

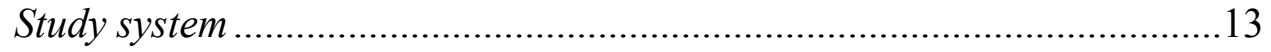

Active bioindicator bioassay .................................................................14

Passive bioindicator survey ................................................................15

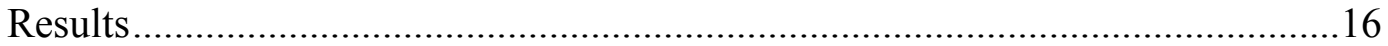

Active bioindicator bioassay ................................................................16

Passive bioindicator survey ..................................................................17

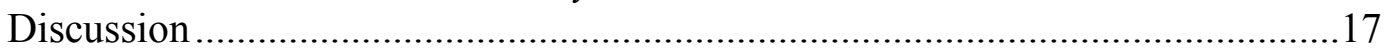
(1)

3

(1)

6

6

(1)

CHAPTER III: Morphological and physiological responses of seagrasses to grazers and

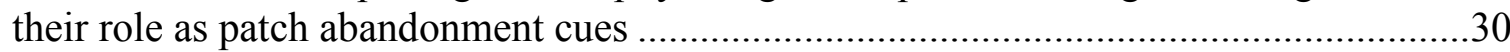

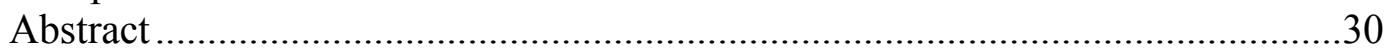

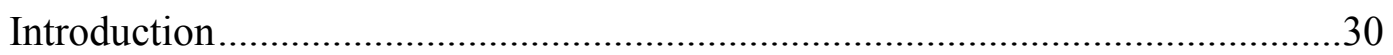

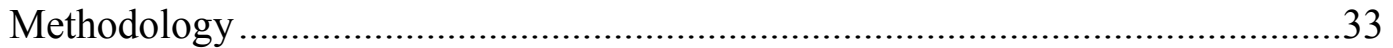

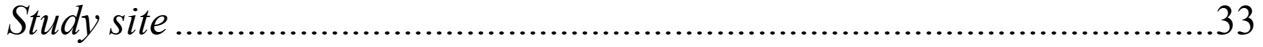

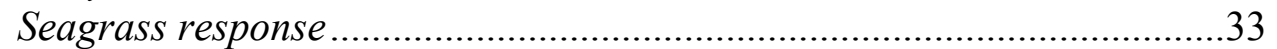

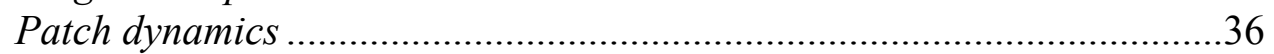

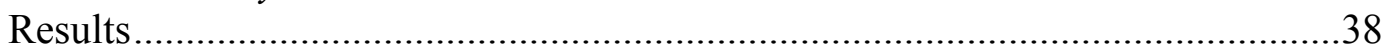

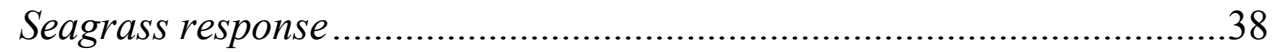

Patch dynamics ..................................................................................

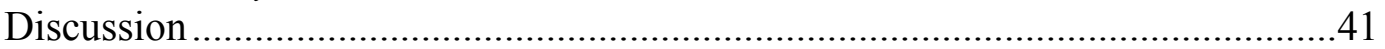

Herbivory in a nutrient-replete seagrass ecosystem ..................................42

Grazer behavior and patterns ..................................................................44

Giving Up Density as a driver to patch abandonments .............................46

CHAPTER IV: Increased algal dominance despite presence of Diadema antillarum

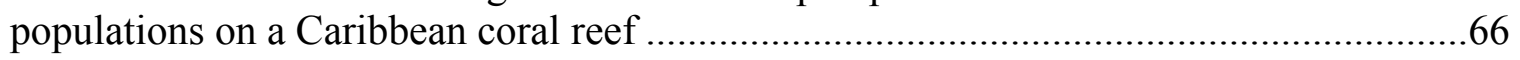

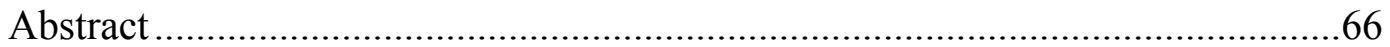

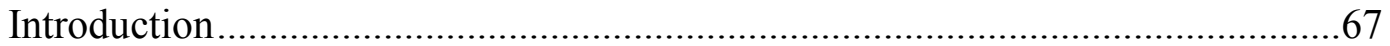

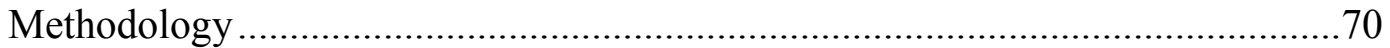

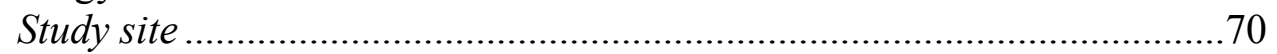

Sampling methodology ......................................................................

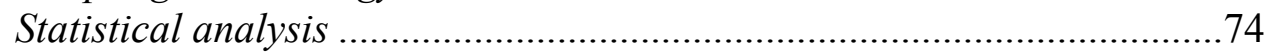

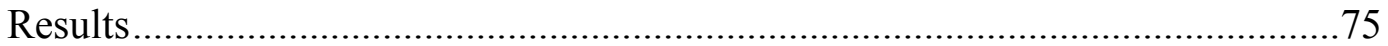


Diadema antillarum density ............................................................. 75

Benthic habitat and correlations with Diadema antillarum density ..........75

Diadema antillarum larval recruitment ..................................................77

Other faunal densities and correlations .............................................77

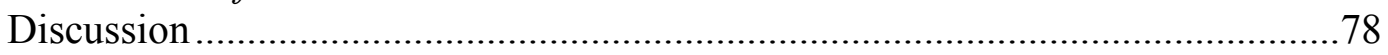

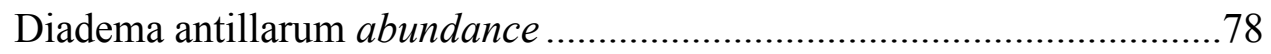

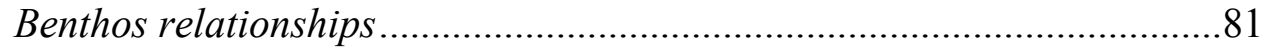

CHAPTER V: Macroalgae genera diversity, richness, evenness and nutrient content relationships over time on an impacted Caribbean coral reef......................................94

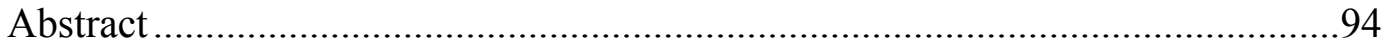

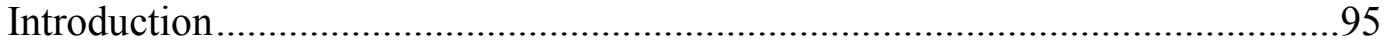

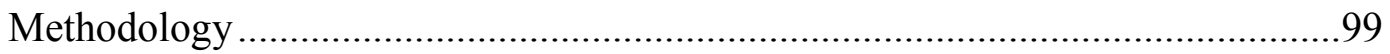

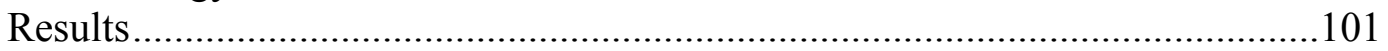

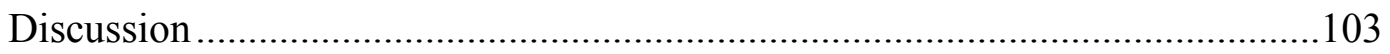

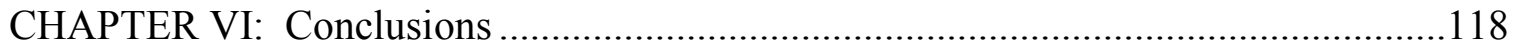

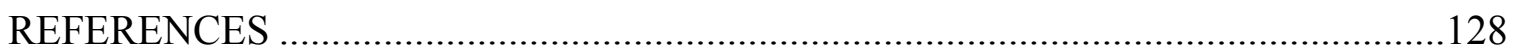

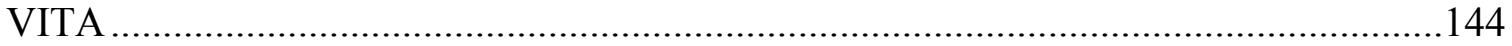




\section{LIST OF TABLES}

TABLE

PAGE

\section{CHAPTER II}

Table 1: Yal Ku Lagoon nutrient content (nitrogen, phosphorus, N:P) and isotopic content of Acanthophora spicifera bioassay in July 2009 and 2010. DW: dry weight. Values are means \pm SE. Significant differences between sites were assessed with ANOVAs and differences determined by pairwise comparisons. Superscripted letters indicate significant difference $(p<0.01)$.

\section{CHAPTER III}

Table 1: Average percent abundance of seagrass in patches within each grazing designation.

\section{CHAPTER IV}

Table 1: Maximum density of Diadema antillarum per $\mathrm{m}^{2}$, frequency of plots without Diadema antillarum and rugosity index by site. ANOVA results for comparisons between all sites each year are given as chi-square value ( $p$-value) with similar sites separated by ' - '

Table 2: Kruskal-Wallis Chi-square $\left(\chi^{2}\right)$ and p-values across all years for each site. Years not significantly different are presented with a '-' between years $(2008=1,2009=$ $2,2010=3 ; 2011=4)$.

Table 3: Spearman rho correlations between Diadema antillarum density on the North and South Backreef with the benthic cover categories and Echinometra lucunter on the North and South Forereef with the benthic cover categories $(n s=$ no significant correlation).

Table 4: Herbivorous fish densities (per $100 \mathrm{~m}^{2}$ ) and biomass $\left(\mathrm{g} / \mathrm{m}^{2}\right)$ at all four sites in 2011

\section{CHAPTER V}

Table 1: Macroalgal genera inventory for Akumal Bay, Quintana Roo, Mexico..... .108

Table 2: Change in benthic cover parameters and diversity indices over four years with average densities of echinoids $\left(\# / \mathrm{m}^{2}\right)(\uparrow$ indicates significant increase in four years, $\downarrow$ indicates significant decrease in four years, -- indicates no significant change in four years) 
Table 3: N:P, nitrogen and phosphorus content for select macroalgae within Akumal Bay, Quintana Roo, Mexico. Nitrogen and phosphorus are percent dry weight and N:P is expressed as the molar ratio.................................................................................110 


\section{LIST OF FIGURES}

FIGURE

PAGE

\section{CHAPTER I}

Figure 1: Drivers to phase shifts on coral- or seagrass-dominated ecosystems. Drivers (dashed lines) decrease the resilience of the current state while positive feedbacks (arrows with plus signs) increase the resilience of the current state.

Figure 2: Grazer disturbance model for seagrass ecosystems (modeled after a mesotrophic environment; Fourqurean et al. 2010). Low grazing intensity leads to seagrasses that are nutrient-limited with higher soluble carbohydrate content relative to aboveground leaf nutrient content. High grazing intensity results in reduced carbon fixation and declining soluble carbohydrates with the potential for seagrass bed collapse.4

Figure 3: Grazer disturbance model for coral reef ecosystems based on the Littler and Littler Relative Dominance Model (Littler et al. 2006). Benthic covers turf and frondose macroalgae are prevalent at low grazing intensities while high grazing intensities reduces these covers and provides space for coral and crustose coralline algae cover. In a high nutrient environment, the Relative Dominance Model would predict frondose macroalgae and crustose coralline algae be present rather than turf and coral

\section{CHAPTER II}

Figure 1: Map of Yal Ku Lagoon, Quintana Roo, Mexico

Figure 2: Percent change in nitrogen content and $\delta^{15} \mathrm{~N}$ of Acanthophora spicifera

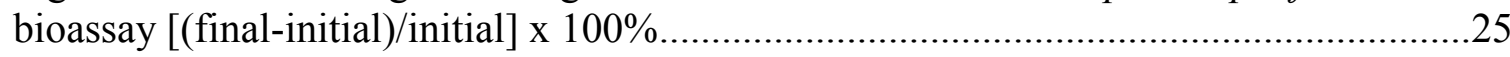

Figure 3: Nitrogen content of all macroalgal species in 2009 (A) and 2010 (B). Bars indicate standard error.

Figure 4: d15N of all macroalgal species in 2009 (A) and 2010 (B). Bars indicate standard error

\section{CHAPTER III}

Figure 1: Patch differentiation as ungrazed (left) and turtle grazed (right). Note the thinner, less dense seagrass in the grazed plot with exposed sediment when compared to the denser, longer Thalassia testudinum blades in the ungrazed plot.

Figure 2: Thalassia testudinum width in all three grazing patches for both seasons winter and summer. Values are patch means \pm SE. Significant differences were assessed with a randomized complete block ANOVA and differences among patches determined through 
pairwise comparisons with Bonferroni corrected significance levels (0.008).

Superscripted letters indicate significant difference between patches in the same season $($ ANOVA $F=12.063, \mathrm{p}<0.001)$

Figure 3: Thalassia testudinum elongation rate and new growth area for both seasons winter and summer. Values are patch means \pm SE. Significant differences were assessed with a randomized complete block ANOVA and differences among patches determined through pairwise comparisons with Bonferroni corrected significance levels (0.008). Superscripted letters indicate significant difference among patches in the same season (Elongation rate ANOVA, $\mathrm{F}=16.993, \mathrm{p}<0.001$; New Growth Area ANOVA, $\mathrm{F}=$ $10.224, \mathrm{p}=0.002)$.

Figure 4: Thalassia testudinum carbon (a), nitrogen (b), phosphorus (c) and soluble carbohydrates (d). Values are patch means \pm SE. Significant differences were assessed with 3-way ANOVAs, and differences among patches determined by pairwise comparisons with Bonferroni corrected significance levels (0.008). Superscripted letters indicate significant difference among patches in the same season (corresponding to the Patch ANOVA F and p-value). Samples sizes are summer, winter: ungrazed $(12,11)$, fish grazed $(6,10)$ and turtle grazed $(12,8)$.

Figure 5: Syringodium filiforme carbon (a), nitrogen (b), phosphorus (c) and soluble carbohydrates (d). Values are patch means \pm SE (ungrazed and turtle grazed only). Significant differences were assessed with 2-way ANOVAs and differences between patches determined by pairwise comparisons with Bonferroni corrected significance levels (0.008). Superscripted letters indicate significant difference between patches in the same season (corresponding to the Patch ANOVA F and p-value). Samples sizes are summer, winter: ungrazed $(4,11)$, fish grazed $(0,1)$ and turtle grazed $(4,8)$.....

Figure 6: Halodule wrightii carbon (a), nitrogen (b), phosphorus (c) and soluble carbohydrates (d). Values are patch means \pm SE (ungrazed and turtle grazed only). Significant differences between winter and summer ungrazed samples were assessed with a student's t-test. Significant differences between summer ungrazed and turtle grazed were assessed with student's t-test (t-test) or Mann-Whitney t-test (M-W), depending on normality of data from the small sample size. Samples sizes are summer, winter: ungrazed $(4,11)$, fish grazed $(0,0)$ and turtle grazed $(0,3)$..

Figure 7: Percentage of patch area in each patch status. Patches that remained ungrazed or remain grazed are the same color as those patches ungrazed or grazed.

Figure 8: Thalassia testudinum within the monitored patches carbon (a), nitrogen (b), phosphorus (c) and soluble carbohydrates (d). Values are patch means \pm SE. Significant differences were assessed with 3-way ANOVAs, and differences among patches determined by pairwise comparisons with Bonferroni corrected significance levels (0.008). Superscripted letters indicate significant difference among patches during the second survey only (corresponding to the Patch ANOVA F and p-value). 
Figure 9: Scatterplot of Thalassia testudinum width by length for initial survey (A) and second survey (B) of patches at three different grazing statuses......................................64

Figure 10: Leaf area biomass and density $\left(\mathrm{mm}^{2} / \mathrm{m}^{2}\right)$ by patch type..............................65

\section{CHAPTER IV}

Figure 1: Map of Akumal Bay, Quintana Roo, Mexico (Latitude: 20 23' 45” N Longitude: $87^{\circ} 18^{\prime} 52^{\prime} \mathrm{W}$ ). Study sites indicated by boxes ( $\mathrm{SF}=$ south forereef, $\mathrm{NF}=$ north forereef, $\mathrm{SB}=$ south backreef, $\mathrm{NB}=$ north backreef).

Figure 2: Density of adult Diadema antillarum (letters indicate significant differences in the same year between sites). Solid circle $=$ south forereef, Open circle $=$ north forereef, solid triangle $=$ south backreef, open triangle $=$ north backreef.

Figures 3A-D: Percent benthic cover for each of the four sites over four years (letters indicate significant differences in the same year between sites). Note the difference in scale between 3A-B and 3C-D. Solid circle $=$ south forereef, Open circle $=$ north forereef, solid triangle $=$ south backreef, open triangle $=$ north backreef.

Figure 4: Density of Echinometra lucunter (letters indicate significant difference in the same year between sites). Solid circle $=$ south forereef, Open circle $=$ north forereef, solid triangle $=$ south backreef, open triangle $=$ north backreef

\section{CHAPTER V}

Figure 1: Map of Akumal Bay, Quintana Roo, Mexico (Latitude: 20 23' $45^{\prime \prime} \mathrm{N}$ Longitude: $87^{\circ} 18^{\prime} 52^{\prime}$ ' W). Study sites indicated by boxes ( $\mathrm{SF}=$ South Forereef, NF $=$ North Forereef, SB = South Backreef, NB = North Backreef).

Figure 2a-c: Shannon-Weiner diversity (H'), species richness (d) and evenness (J) for all four sites from 2008-2011 in Akumal Bay. Letters indicate significant difference at each site among years

Figure 3a-c: Nitrogen and phosphorus content (a) and N:P (b) of Halimeda spp. DW: dry weight. Significant differences were assessed with an ANOVA across all sites to detect differences among years. Letters indicate significant difference among years....117

\section{CHAPTER VI}

Figure 1: Conceptual model indicating the drivers to shifts within the seagrass ecosystem of Akumal Bay, Quintana Roo, Mexico. Dashed lines indicate the decreased resilience caused by the drivers eutrophication, herbivory and herbivore loss or continual herbivory 
Figure 2: Grazer disturbance model for Akumal seagrass ecosystems. Low grazing intensity leads to light limited seagrasses with higher soluble carbohydrate content relative to aboveground nutrient content. High grazing intensity results in reduced carbon fixation and an increase in relative nutrient content of aboveground nutrient tissue and significantly less soluble carbohydrates (solid line as opposed to originally theorized dashed line). Biomass may be the important driver to seagrass patch abandonment as a potential giving up density is reached at high grazing intensities.

Figure 3: Conceptual model indicating the drivers to shifts within the coral reef ecosystem of Akumal Bay, Quintana Roo, Mexico. Dashed lines indicate the decreased resilience caused by drivers and the circular arrow with a plus sign indicates positive feedbacks to the TAS dominated state.

Figure 4: Grazer disturbance model for Akumal coral reef ecosystems. Dashed lines indicate the original model while solid lines indicate those results recorded during this survey. $(\mathrm{CCA}=$ crustose coralline algae $)$. 


\section{CHAPTER I: Introduction}

Human populations are rapidly increasing and altering nearshore marine environments, particularly as $60 \%$ of the population is concentrated within $100 \mathrm{~km}$ of the coast (Vitousek et al. 1997). With these high densities, record high levels of nitrogen and phosphorus are being introduced to the coastal ecosystems and resources such as fisheries are becoming increasingly exploited (Cloern 2001, Halpern et al. 2008). As $41 \%$ of marine ecosystems are impacted by multiple drivers (e.g., both eutrophication and overharvesting), rates of ecosystem loss have increased for nearshore ecosystems such as seagrasses, mangroves and coral reefs (Vitousek et al. 1997). These losses are of great importance both ecological and economically as shallow marine ecosystems provide tourism and fisheries income, stabilize sediment, protect shorelines and cycle nutrients, among many other important roles (Costanza et al. 1997, Waycott et al. 2009). For these reasons, marine ecosystem managers have an urgent need to identify indicators and quantify responses of primary producers to these drivers over time, as it is the primary producers which form the base of the food web and can efficiently indicate ecosystem health. There is also a need to assess ecosystem status and determine the influence of these drivers on ecosystem status or the potential for a phase shift to a different ecosystem state.

A phase shift is what occurs when an ecosystem experiences a fundamental change in core processes in response to drivers (Figure 1; Scheffer et al. 2001, Collie et al. 2004, Andersen et al. 2008). Each ecosystem has a unique capacity to buffer perturbations and return to the original state without experiencing a permanent phase shift to an alternative state (Nystrom et al. 2000). This capacity, termed resilience, can be 
influenced by the relative dominance of each ecosystem component as it changes with different ecosystem processes (e.g., resource availability, herbivore disturbance), further examples are explored in Scheffer et al. (2001). Dominance of one species can be driven by the abundances of other species as they interact through factors such as population dynamics, competition and predation (Knowlton 1992), which may also operate as positive feedback mechanisms. Positive feedback mechanisms are self-stabilizing actions that serve to increase the resilience of the system's current state (Scheffer et al. 2001). In addition to external drivers, removal or reduction of these internal positive-feedbacks is often necessary for a phase shift to an alternative state to occur (Petraitis \& Latham 1999).

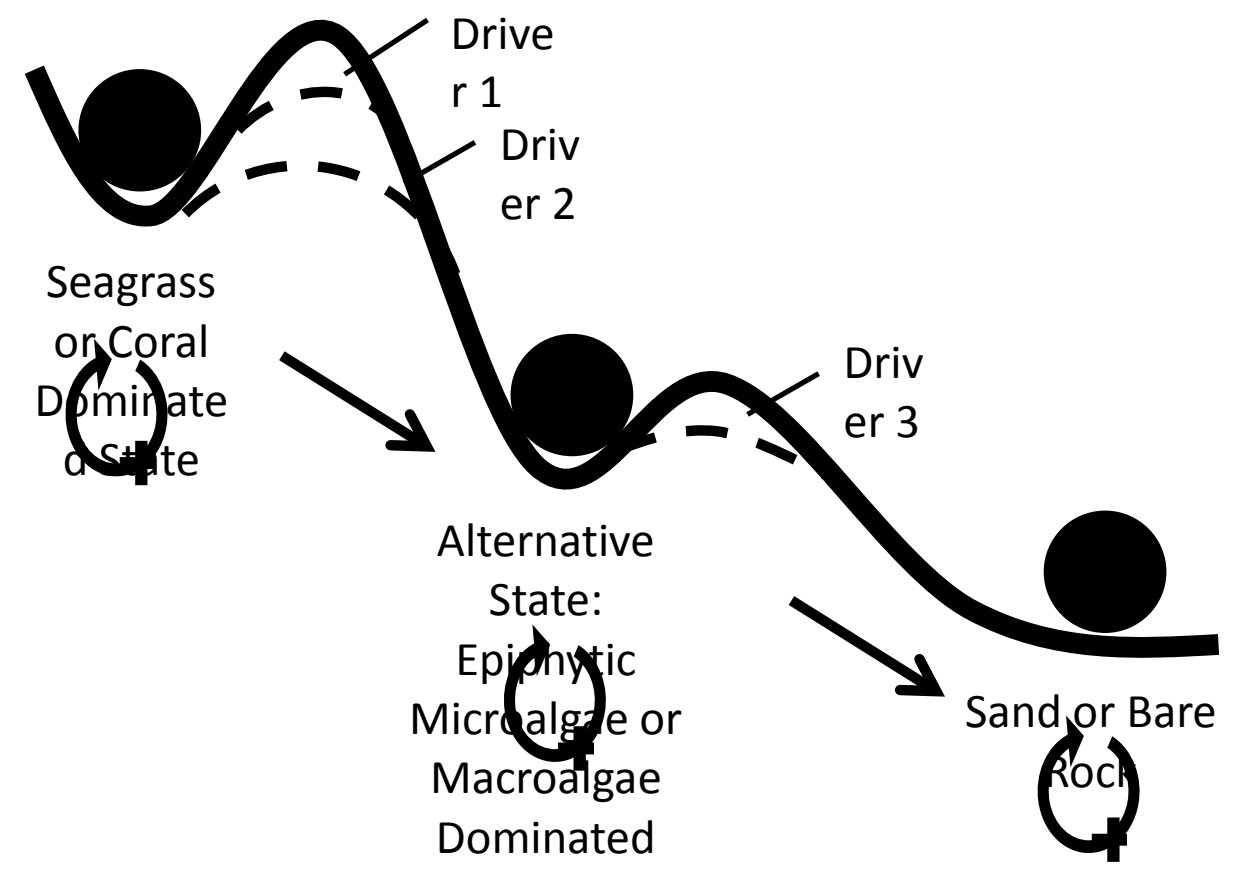

Figure 1: Drivers to phase shifts on coral- or seagrass-dominated ecosystems.

Drivers (dashed lines) decrease the resilience of the current state while positive feedbacks (arrows with plus signs) increase the resilience of the current state. 
Coastal marine ecosystems

Seagrasses are marine vascular plants common in coastal waters worldwide. They are the base of marine food webs, forming a trophic connection including sirenians (manatees and dugongs), turtles, herbivorous fish, sea urchins and waterfowl (Valentine \& Heck 1999). Seagrass bed state dynamics include a clear, seagrass dominated state and a turbid, epiphytic microalgae dominated state characterized by phytoplankton blooms (Gunderson 2001). The epiphytic microalgae state is used to refer to those conditions in which seagrass have high epiphyte loads and the water is turbid with high phytoplankton biomass. The relative dominance of each of these alternative states is driven by nutrient availability and herbivory. For shifts from seagrass dominated states to epiphytic states, perturbations from eutrophication alter seagrass abundance, resource use and productivity (Borum 1985, Orth et al. 2006), parameters that can be monitored to indicate ecosystem state. Positive feedbacks to the resilience of a clear, seagrass dominated state occur through the stabilization of sediments by seagrass rhizomal mats (Ginsburg \& Lowenstam 1958, Scoffin 1970). In a nutrient replete system, the benthos would be expected to exist as a turbid, epiphytic microalgal-covered state rather than a clear water, seagrass dominated state. In Florida Bay, nutrients have driven the seagrass system from a clear to turbid state with frequent sediment resuspension and algal blooms as the positive feedback mechanisms by which this turbid state exists (Fourqurean \& Robblee 1999). Opportunistic epiphytic overgrowth reduces light penetration to seagrass blades and limits successful seagrass recolonization (Ferreira et al. 2007), thus increasing the resilience of this alternative turbid state as seagrasses are competitively excluded (Tomasko \& Lapointe 1991). 
An additional driver is through herbivore grazing disturbance. In the absence of herbivory, areas experiencing high nutrient loads would be expected to shift from relatively clean seagrass blades to blades dominated by epiphytic microalgae (Neckles et al. 1993, McGlathery 1995). However, grazing stimulates seagrass productivity from the extensive networks of belowground biomass to offset the loss of aboveground biomass (Valentine et al. 1997). Resource allocation is mobilized from storage in rhizomes to the production of new leaves aboveground. The status of the seagrass ecosystem is reflected in rates of primary production, seagrass abundance and measurements of nutrient reserves in rhizomes (carbon, nitrogen, phosphorus and soluble carbohydrates), but the direct effects of grazing behaviors on these parameters is not well known although it has been modeled in mesotrophic environments (Figure 2).

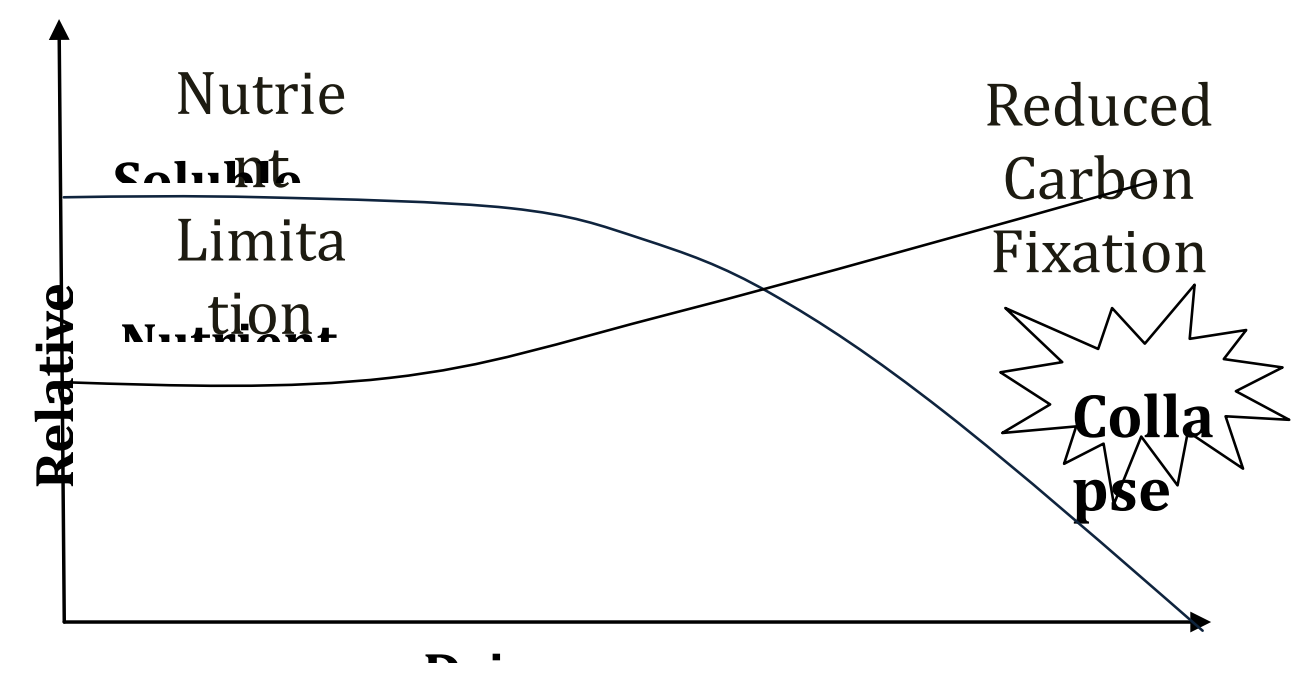

Figure 2: Grazer disturbance model for seagrass ecosystems (modeled after a mesotrophic environment; Fourqurean et al. 2010). Low grazing intensity leads to seagrasses that are nutrient limited with higher soluble carbohydrate content relative to 
aboveground nutrient content. High grazing intensity results in reduced carbon fixation and declining soluble carbohydrates with the potential for seagrass bed collapse.

Relative dominance of coral reef alternative states is also driven by nutrient availability and herbivory (Hughes 1994, Lapointe 1999, Szmant 2002). These ecosystems are also impacted by coral diseases and ocean acidification but as it is not feasible for marine ecosystem managers to mitigate for these indirect drivers (McManus \& Polsenberg 2004), it become more important to focus on these top-down (herbivory) and bottom-up (nutrient) drivers. Shifts from coral- to algal-dominated states can occur when there is an increase in nutrients to the system, which favors the growth of macroalgae as they competitively exclude corals (Idjadi et al. 2006). Nutrients impact macroalgal productivity and this can be measured in tissue concentrations of nitrogen and phosphorus. For many macroalgae species, their relationship with nutrients is not well established and warrants further consideration. Information on nutrient dynamics will be of particular interest as a parameter by which to monitor the effects of nutrient enrichment on the coral-algal relationship. Positive feedbacks to the macroalgae state include reductions in habitat complexity (Lee 2006), decreased coral recruitment from the Allee effect, and increased turbidity and sedimentation that commonly occurs in algaldominated systems (Knowlton 1992).

Alterations in grazers impact the dominant benthic cover and therefore the state of the coral reef ecosystem. Herbivores directly impact macroalgal dominance through the removal of biomass, which provides space for coral recruitment. Events like the massive mortality of the herbivore Diadema antillarum throughout the Caribbean in the 1980s, released macroalgae from herbivory pressure, which increased algal abundance. After 
the loss of this herbivore, many reefs experienced a dramatic shift to increased macroalgal cover from formerly coral-dominated reefs (Lessios et al. 1984a, de Ruyter van Steveninck \& Bak 1986). As the sea urchin population begins to recover, their grazing may serve as a buffer to excessive nutrients in a similar manner as sea turtles in seagrass beds. Correlations between parameters such as sea urchin density and macroalgal abundance and distribution are especially important when considering these ecosystems are under an additional stress of high nutrient availability.

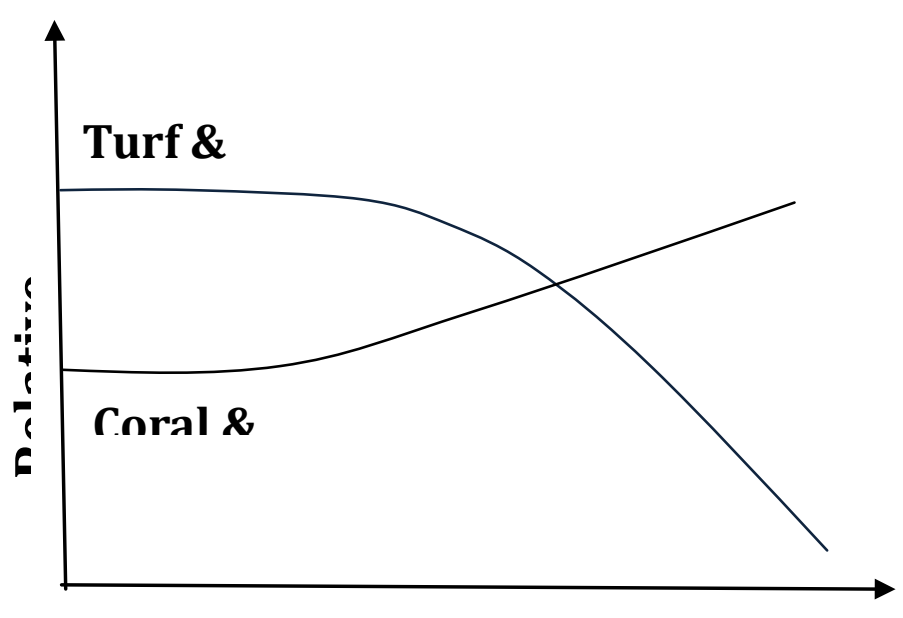

nrivor.

Figure 3: Grazer disturbance model for coral reef ecosystems based upon the Littler and Littler Relative Dominance Model (Littler et al 2006). Benthic covers turf and frondose macroalgae are prevalent at low grazing intensities while high grazing intensities reduces these covers and provides space for coral and crustose coralline algae cover. In a high nutrient environment, the Relative Dominance Model would predict frondose macroalgae and crustose coralline algae be present rather than turf and coral. Understanding the drivers underlying resilience in nutrient replete environments is crucial to preventing continued degradation. There are many gaps in the ecological theory of herbivore- and nutrient-induced changes to primary producer assemblages and 
no known studies which consider multiple systems (seagrass and coral) within the same shallow marine environment. Studying multiple systems provides interesting insight into the responses of primary producers to similar nutrient scenarios and is a mechanism by which similar questions can be asked in these different ecosystems. An expansion in our understanding of the mechanisms affecting dominant benthic habitat and potentially ecosystem resilience can be beneficial for marine park management decisions and priorities. During this research, I first considered the macroalgal response to nutrients and the importance of their use as nutrient bioindicators within my study region of Akumal, Mexico (Chapter II). These data can determine the relative nutrient availability to the primary producer community within the Mesoamerican coastal region and the accuracy in designating this system as nutrient replete rather than nutrient limited. I then sought to evaluate the impact of green sea turtles, Chelonia mydas, and herbivorous fish on dominant seagrass state as the primary producers are impacted by high nutrient availability (Chapter III). There are many unanswered questions regarding the physiological and morphological response of seagrasses to grazing in a eutrophic environment as well as how these parameters relate to observed grazer behavior. In a similar manner to herbivores in seagrass beds, I also considered the role of herbivorous black-spined sea urchins, Diadema antillarum, on structuring the algal dominant state in Akumal Bay (Chapter IV). Beginning with a consideration of the recovery dynamics of the sea urchin, I also sought to analyze the impact of this driver on benthic cover functional groups and what changes in benthic cover over time mean to overall coral reef ecosystem state. Finally, I analyzed how high nutrient availability could impact changes in generic diversity and nutrient content of macroalgae (Chapter V). These data are 
considered with results on herbivory found during Chapter IV in order to determine the trajectory of this highly impacted coral reef ecosystem as it is impacted by the increasingly common drivers of eutrophication and fishing exploitation. Results from the research produced during these studies answers ecological questions on the relative importance of these drivers on primary producer assemblages in nutrient-replete ecosystems. Results can also provide important information to assist marine park managers in their quest to protect these important ecosystems. 
CHAPTER II: Challenges in using marine macroalgae tissue chemistry for assessing nutrient pollution in the Mexican Caribbean

Abstract

Rising coastal populations are rapidly driving changes in nearshore marine environments through increased anthropogenic nutrient loading. Monitoring the response of primary producers such as macroalgae to these nutrients is an important management priority yet data are lacking on even the most basic ranges to be expected for tissue nutrients. My study was designed to add to the paucity of nutrient literature as well as utilize two different bioindicator methodologies to determine the fate of nutrients on $\delta^{15} \mathrm{~N}$, nitrogen and phosphorus content within Yal Ku Lagoon, Akumal, Quintana Roo, Mexico, an ecosystem considered to be heavily impacted by anthropogenic nutrients. Bioindicators are continuous samplers of the aquatic environment and provide data on the bioavailability of nutrients to primary producers, such as macroalgae. In July 2009 and 2010, nitrogen, phosphorus and $\delta^{15} \mathrm{~N}$ content of Acanthophora spicifera were used as an active bioindicator bioassay to record nutrients within the water column while a collection of macroalgae was also completed as passive macroalgae indicators to record nutrients available at the benthos. While the bioassay of $A$. spicifera did signify some dilution of nutrient content with distance in 2010, clear isotopic indications of this pattern were absent in 2009. Tracking nitrogen (maximum 4\% dry weight) and phosphorus (maximum $0.18 \%$ dry weight) tissue content in both active and passive macroalgal bioindicators suggest $\mathrm{Yal} \mathrm{Ku}$ Lagoon is a nutrient replete ecosystem but data are highly variable. While macroalgae bioindicators can indicate the relative nutrient status and bioavailability within the system, the diffuse sources of nutrients coming from this karstic 
environment may not allow clear tracking of gradients in nutrient pollution. My study contributes valuable data which can be used to increase our understanding on the fluctuating ranges of $\delta^{15} \mathrm{~N}$ and nitrogen content within marine macroalgae. My study also illustrates the variability between bioindicator methodologies and parameters and therefore their use and interpretation for management purposes. Introduction

Globally, human populations are rapidly increasing and altering nearshore marine environments with anthropogenic nutrient loading (Cloern 2001). Increased nutrients, such as nitrogen from fertilizers and sewage, increases primary productivity (Doering et al. 1995, Thornber et al. 2008) and can cause the formation and proliferation of macroalgal blooms (Lapointe 1997, Stimson et al. 2001). Effective monitoring of indicators preceding such macroalgal blooms could allow for corrective actions to reduce nutrient loading prior to detrimental blooms. Traditionally, testing of the water column has been used to monitor levels of nutrients available within an ecosystem (Burford et al. 2003, Biao et al. 2004). However, when terrestrial nitrogen arrives in spatially or temporally variable pulses, measurements of short-term water column chemistry do not represent the long-term influence or bioavailability of these nutrients (Fong et al. 1998, Fong et al. 2004). Measurements of primary producer tissue chemistry represent timeintegrated nutrient availability which dampens short-term fluctuations (Fourqurean et al. 1997). These primary producer measurements also allow an understanding of eutrophication to be developed in an ecologically relevant way (Savage \& Elmgren 2004). 
While macroalgal response may differ depending on species as there are physiologically different uptake rates and storage capacities (Wallentinus 1984), internal content generally reflects external conditions (Gerloff \& Krombholz 1966, Lyngby 1990, Lapointe et al. 1992). As such, tissue chemistry is a function of spatial and temporal patterns in nutrient availability and the demand from the primary producer for those nutrients for growth (Redfield 1958, Gerloff \& Krombholz 1966, Atkinson \& Smith 1983). Macroalgae are also easy to collect and prepare, can integrate available nutrients over time (Cohen \& Fong 2005, Costanzo et al. 2005) and their fast uptake rates make them ideal for bioassay techniques (Wallentinus 1984, Costanzo et al. 2001). Tissue nitrogen and phosphorus concentration, $\delta^{15} \mathrm{~N}$ and productivity are part of the suite of parameters considered in the use of macroalgae as a method by which to estimate relative availability of nutrients within an ecosystem (Horrocks et al. 1995, Fong et al. 1998, Umezawa et al. 2002, Lin \& Fong 2008, Dailer et al. 2010). Algal tissue chemistry can be used passively through the sampling of species present naturally within the environment or actively through the deployment of bioassay species that are transplanted from their natural environment and incubated in areas under observation (Costanzo et al. 2000). As passive bioindicators have holdfasts within the sediment, these indicate the benthic availability of nutrients while the positioning of active bioindicators above the substrate more accurately sample water column nutrient availability. The use of both techniques can provide a more accurate understanding of the temporal and spatial pattern in nutrient availability within an ecosystem and could be used to infer potential nutrientdriven macroalgal blooms. 
Specific stable isotope signatures can be used to trace sources of nutrients within an ecosystem (Heaton 1986, Peterson \& Fry 1987). For instance, high ratios of ${ }^{15} \mathrm{~N}:{ }^{14} \mathrm{~N}$ can indicate the presence of sewage while naturally high $\delta^{15} \mathrm{~N}$ can also occur through denitrification, fractionation during nitrate uptake and overlapping or multiple nutrient sources (Heaton 1986, Fourqurean et al. 1997). For this reason, interpretation of $\delta^{15} \mathrm{~N}$ data should be done utilizing corroborating data for perceived trends and potential sources. For instance, spatial patterns comparing nitrogen content and $\delta^{15} \mathrm{~N}$ can indicate variation in signals arising from nutrient sources rather than differences in nutrient uptake processes (Leichter et al. 2003, Savage \& Elmgren 2004). While research does suggest that many macroalgal species do not fractionate nitrogen isotopes (Cohen \& Fong 2005), interpretation of $\delta^{15} \mathrm{~N}$ data requires corroboration with other nutrient data.

I examined nitrogen, phosphorus and $\delta^{15} \mathrm{~N}$ content of macroalgae in both an active and passive bioassay methodology to determine the impact nitrogen loading had on the benthic assemblages in a region where nitrogen impact had been recorded in octocorals (Baker et al. 2010). I ask the question: Do parameters of macroalgae tissue chemistry (nitrogen, phosphorus, $\delta^{15} \mathrm{~N}$ ) in active and passive macroalgae bioindicators reflect spatial patterns in reference to suspected nutrient source? Utilization of both active and passive bioindicator methodology allowed me to determine if trends differed between methods as both have been presented in literature but no comparisons have been previously published. I also wanted to contribute to the paucity of literature reporting nitrogen and $\delta^{15} \mathrm{~N}$ values for marine macroalgae. Despite the prevalence of literature suggesting ${ }^{15} \mathrm{~N}$ isotopic data can be used to detect anthropogenic nutrients, isotopic data with corroborating nitrogen content are lacking. 
Methodology

Study system

Millions of tourists visit the Mayan Riviera region of Mexico’s Yucatan Peninsula and rapid coastal development has intensified sewage inputs to coastal areas (Murray 2007). The Yucatan Peninsula is characterized by karstic geology, where stream flow of pollutants directly into the water is uncommon and groundwater is conducted from inland into the nearshore environment through submarine groundwater discharge. While most resorts have on-site wastewater treatment, many residences lack proper sewage disposal methods (Pacheco et al. 2001) and groundwater is commonly contaminated with pollutants indicative of human waste (Baker et al. 2010, Metcalfe et al. 2011). Yal Ku Lagoon, Akumal, Quintana Roo, Mexico $\left(20^{\circ} 24.702 \mathrm{~N},-87^{\circ} 18.27 \mathrm{~W}\right)$ is a popular tourist destination as clear water and submerged aquatic vegetation provide a suitable habitat for abundant fish and frequent visits by manatees, stingrays and turtles. The Lshaped lagoon has a rocky coast interspersed with red mangroves (Rhizophora mangle). Yal Ku Lagoon is 300 meters in length and turns sharply east before continuing 300 meters to the ocean entrance (Figure 1). Within my study region, Thalassia testudinum and Gorgonia ventalina isotopic ratios, phosphorus and nitrogen concentrations, as well as water quality of the underground cave system, indicate groundwater sources of nutrients and pollutants (Carruthers et al. 2005, Mutchler et al. 2007, Baker et al. 2010, Metcalfe et al. 2011). Previous research in Yal Ku Lagoon has documented decreasing $\delta^{15} \mathrm{~N}$ of octocorals, and water column Enterococcus coliform bacteria, an organism indicative of human sewage, with increasing distance from the suspected lagoon spring source (Baker et al. 2010). 


\section{Active bioindicator bioassay}

Acanthophora spicifera was used as an active bioindicator as this species is ubiquitous on the adjacent reefs and has proven hardy to these types of bioassay experiments taking place within the water column (Lin \& Fong 2008). Acanthophora spicifera was collected in Akumal Bay and gently cleaned of epiphytes. In order to reduce macroalgal initial nutrient content, macroalgae were placed in a plastic tub with two electric air stones while water was changed every two days for six days (Fong et al. 2003, Lin \& Fong 2008, Dailer et al. 2010) with water collected offshore. The bucket of macroalgae was placed inside a larger plastic bin of water to decrease the potential for overheating from ambient temperatures and received diffuse natural light for approximately ten hours each day. Thirty-six A. spicifera replicates were created with six replicates retained in order to determine the initial concentrations of nitrogen, phosphorus and $\delta^{15} \mathrm{~N}$. Six replicates per site were sewn inside mesh bags and placed at five locations throughout the lagoon at increasing distances from the suspected lagoon source in July 2009 and twice in July 2010 (Figure 1, black stars). All bags were placed along the bottom at the same depth and attached to rocks using cable ties. After seven days, samples were recovered, removed from the mesh bags and gently cleaned of epiphytes. Seven days was determined to be adequate deployment length on the basis of previous studies (Fong et al. 1998, Lin \& Fong 2008). Samples placed at the lagoon source (0m) and at the juncture of the ocean entrance and source lagoon $(300 \mathrm{~m})$ were lost therefore only the samples at $400 \mathrm{~m}, 550 \mathrm{~m}$ and $700 \mathrm{~m}$ are presented (sample sizes are indicated in Table 1). My initial design included increased spatial coverage and productivity measurements utilizing Alizarin Red S dye (Wefer 1980), however the reality of working 
in this tourist destination precluded data collection as these samples were removed from the lagoon before researchers could retrieve them.

All samples were dried to a constant weight at $60^{\circ} \mathrm{C}$ and ground to a fine powder using a mortar and pestle. Samples were analyzed in duplicate for nitrogen content using a CHN analyzer and for phosphorus using dry-oxidation acid-hydrolysis extraction followed by colorimetric analysis. Dry weight elemental content was calculated as (mass of element/dry weight of sample) x $100 \%$. As simple measures of tissue nutrients do not take into consideration initial nutrient concentrations (Fong et al. 1998), percent change of nitrogen and phosphorus was also calculated. Isotopic analysis $\left(\delta^{15} \mathrm{~N}\right)$ was completed with a CN analyzer and Finnigan MAT 252 mass spectrometer and are expressed using the standard $\delta^{15} \mathrm{~N}$ notation (Peterson \& Fry 1987). Samples from both bioassay deployments in July 2010 were pooled because samples were not significantly different from each other (Student's t-test, $p=0.889$ ). An ANOVA was used to test for significant differences between bioassay sites during each sampling event after examination of standardized residuals showed data conformed to assumptions of normality.

\section{Passive bioindicator survey}

To determine if trends in nitrogen, phosphorus and $\delta^{15} \mathrm{~N}$ differed depending on bioindicator methodology, a passive bioindicator survey was also completed. A survey of all macroalgae present along the lagoon was completed. Four to five samples of each macroalgae species present were collected at the source and along a sampling transect in $50 \mathrm{~m}$ increments from the juncture of the ocean entrance and source lagoon $(400 \mathrm{~m})$ to the ocean entrance (700m) in July 2009 and 2010 (Figure 1, solid black line). For Caulerpa species, only three replicates could be collected because of the paucity of samples and the 
relatively small size of these macroalgae. Samples were processed in an identical manner for nitrogen, phosphorus and $\delta^{15} \mathrm{~N}$ as during the bioassay. When the same genera were found along the transect in the same year and standardized residuals established that data conformed to normality assumptions, an ANOVA was used to test for significant differences between locations. When the same genera only appeared twice along the transect, a Student's t-test was used to test for significant differences. Results

Macroalgae within the first 400 meters from the suspected source of Yal Ku Lagoon were limited to sparse Halimeda opuntia and Caulerpa verticillata. From 400m $-700 \mathrm{~m}$, the benthos changed and included other calcareous green macroalgae (e.g., Udotea, Penicillus), red macroalgae (e.g., Laurencia) and brown macroalgae (e.g., Stypopodium, Dictyota). From 550m to the ocean entrance $(700 \mathrm{~m})$, there were octocorals, Gorgonia ventalina, and zoanthids, Palythoa caribaeorum. Active bioindicator bioassay

In 2009, tissue chemistry of the active bioindicator bioassay increased significantly from $400-550 \mathrm{~m}$ from the suspected source before values significantly decreased (Table 1) and this pattern was reflected in all measured nutrient parameters (P, $\mathrm{N}$ and $\delta^{15} \mathrm{~N}$ ). During the 2010 bioassays, nitrogen content, nitrogen: phosphorus and $\delta^{15} \mathrm{~N}$ decreased away from the suspected source while phosphorus content did not change significantly (Table 1). Acanthophora spificera tissue nitrogen $(\mathrm{N})$ ranged from $0.8-1.0$ $(\% \mathrm{DW})$, tissue phosphorus $(\mathrm{P})$ ranged 0.04-0.06 (\%DW), nitrogen:phosphorus $(\mathrm{N}: \mathrm{P})$ were $39-57$ and $\delta^{15} \mathrm{~N}$ values were 2.4-6.2\%o (Table 1). In 2010, there was a positive trend between change in nitrogen content and change in $\delta^{15} \mathrm{~N}$ as nutrient and $\delta^{15} \mathrm{~N}$ decreased 
with increasing distance from suspected source. The trend was not observed in 2009 (Figure 2).

Passive bioindicator survey

During the 2009 and 2010 passive benthic bioindicator survey, Caulerpales (Caulerpa and Halimeda) were the common macroalgae present. Trendlines of nitrogen content and $\delta^{15} \mathrm{~N}$ along transect length are presented for these macroalgae genera to determine trends in these parameters with increasing distance from suspected source. In 2009, Halimeda tissue nitrogen significantly decreased with distance from source $(\mathrm{p}<$ $0.05)$ while Caulerpa tissue nitrogen content did not significantly change $(p=0.977$; Figure 3a). In 2010, Caulerpa tissue nitrogen significantly decreased with distance from source $(\mathrm{p}<0.05)$ while Halimeda did not significantly change $(\mathrm{p}=0.897$; Figure $3 \mathrm{~b})$. Further trends could not be determine because of a lack of replicate genera along the transect. In 2009, $\delta^{15} \mathrm{~N}$ of Caulerpa and Halimeda significantly increased with distance from source ( $\mathrm{p}<0.05$; Figure 4a) while in 2010, Caulerpa $\delta^{15} \mathrm{~N}$ significantly increased with distance from source $(\mathrm{p}<0.05$; Figure $4 b)$.

Discussion

Tracking nitrogen, phosphorus and isotopic content through the use of Acanthophora spicifera active bioindicators and a diversity of macroalgae genera as passive bioindicators indicate macroalgae response to nutrients in Yal Ku Lagoon is highly variable. However, as distance from suspected nutrient source increased, a decrease in nutrient content of both bioassay and sampled macroalgae occurred, but patterns were year and genera specific. In 2010, the bioassay of $A$. spicifera within the water column indicated a decrease in nitrogen availability and $\delta^{15} \mathrm{~N}$ with distance from 
the suspected source of anthropogenic nutrient input but this trend did not occur in 2009 . Data from this study can be used to provide evidence for the macroalgal uptake of nitrogen and phosphorus nutrients and the importance of using both tissue nitrogen and isotopic data to understand the fate of anthropogenic nutrients into a system. My study contributes valuable data which can be used to increase our understanding on the fluctuating ranges of $\delta^{15} \mathrm{~N}$ and nitrogen content within marine macroalgae.

Tissue content of nutrients and ratios of these nutrients when compared to standards can determine nutrient limitation to macroalgae growth. In general, macroalgae nitrogen content greater than 1.2 percent dry weight ( $\%$ DW), phosphorus content less than $0.02(\% \mathrm{DW})$ and nitrogen:phosphorus higher than 30 can indicate a phosphorus-limited system (Atkinson \& Smith 1983, Duarte 1992). However, macroalgae have proven to be highly variable rather than conforming to these established 'baselines.' Prior to this study, few studies have reported nutrient content on such a diverse group of macroalgae within the Mexican Caribbean from which to infer relative nutrient status. For those references within the literature in Akumal Bay Mutchler and Dunton (2007) reported Halimeda nitrogen of 1 (\% DW) while my sampled Halimeda had nitrogen maximum 1.6 (\% DW). Tissue nitrogen content of Acanthophora spicifera used in a bioassay directly adjacent to shrimp farms was $1.2(\% \mathrm{DW})$ and decreased to 0.8 (\% DW) 400m from the shrimp farm (Lin \& Fong 2008). In this study A. spicifera peaked at $1.0(\% \mathrm{DW})$, which while not greater than those measured next to the shrimp farm, are comparably higher than those areas deemed 'less impacted' by the shrimp effluent. Records of marine macroalgae nutrient content are sparse and this study adds to 
our understanding on the ranges of nutrients possible within an ecosystem considered impacted by anthropogenic effluent.

Use of $\delta^{15} \mathrm{~N}$ in bioindicators has frequently been cited as clear evidence to the presence of sewage near outfalls and an effective way to measure increased pollutant dilution with increased distance from source (Costanzo et al. 2001, Costanzo et al. 2005, Lin \& Fong 2008, Dailer et al. 2010). Elevated $\delta^{15} \mathrm{~N}$ values can occur through spatial differences in $\mathrm{NO}_{3}{ }^{-}$enrichment, denitrification and the mixing that occurs during groundwater transport (Fourqurean et al. 1997) in addition to the presence of sewage (Heaton 1986). In some research, $\delta^{15} \mathrm{~N}$ was the most sensitive indicator when compared to other parameters such as tissue nitrogen (Lin \& Fong 2008), while in other published datasets, parameters such as tissue nitrogen, amino acids and chlorophyll a concentrations have provided adequate indicators of nutrient status (Costanzo et al. 2000). For studies on marine macroalgae, values of 3\% have previously been reported for Akumal Bay Halimeda and 3.0-8.0\%o for multiple genera in southeast Florida with global ranges from 4-25.7\%o in reported sewage impacted areas (Lapointe et al. 2004, Mutchler et al. 2007, Dailer et al. 2010). Most often, as was found during my study, it is a combinations of multiple parameters that should be used to make statement regarding nutrient status and impacts (Fong et al. 2001).

Interpretation of data from passive bioindicators can be difficult as differential responses of each macroalgae species impact the nutrient signature. Differences in nitrogen content can be driven by chemical defenses, pigmentation (Delgado et al 1996) or growth morphologies (Littler \& Littler 1980, Fong et al. 2001). These types of relationships are unknown for many of the genera found during this study and pooling 
data by genera may mean important nuances to trends are missed. In addition, species or genera were not consistently present along the entire length of the sampling transect, making determinations of any nutrient dilution with distance difficult to establish. When the same genera was present at multiple locations along the sampling transect (e.g., Halimeda, Caulerpa), trends in nitrogen content did not clearly indicate a dilution of nutrients with increasing distance from suspected source. Despite the multitude of factors that can influence any comparisons between macroalgae genera within an ecosystem, it is important to note that nitrogen content was sensitive enough to detect changes at short distances through time while $\delta^{15} \mathrm{~N}$ did not detect these same changes. In karstic environments such as the Mexican Caribbean, fissures can create a diffuse delivery of nutrients into the environment rather than creating distinct point sources (Metcalfe et al. 2011). The identification of the sources is important not only to the interpretation of nutrient data, but also to the management strategies developed to address the sources of these nutrients. It is conceivable that because the underground cave system beneath Yal Ku Lagoon is not completely mapped, fissures away from my suspected source location may contribute nutrients along the transect. Although this hypothesis is compounded by the fact that a distance effect was recorded in 2010 and in previous studies (Baker et al. 2010). As shoreline development continues along the Mayan Riviera (Murray 2007), the importance of each of these potential sources into the adjacent coastal ecosystem increases. The lack of baseline information mapping all potential sources and the pathways through subterranean cavern systems may limit our understanding of nutrients within Yal Ku Lagoon, and therefore the ability to manage these influences. 
In highly eutrophic locations, macroalgae sensitivity to nitrogen availability is compromised as the macroalgae is saturated with nutrients (Cohen \& Fong 2005). Alternatively, in some studies macroalgae indicators failed to respond to low levels of nutrient pollution (Costanzo et al. 2000). The ideal scenario at which these bioindicators can be used is highly variable and dependant on the questions being asked and the historic information available regarding the study system. In order to determine the dilution of nutrient sources in Yal Ku Lagoon, the ideal usage of macroalgae may be to use genera such as Acanthophora or Enteromorpha in active bioassay methodology rather than passive sampling of benthic communities, which differed in presence along the transect. The active bioassay sampled the water column and detected trends in $\delta^{15} \mathrm{~N}$ and nitrogen content that passive bioindicators sampling along the benthos did not detect. It may be that processes occurring within the sediment reduce ${ }^{15} \mathrm{~N}$ and therefore its presence in macroalgae. Many factors exist that can influence nitrogen and phosphorus of macroalgae within an ecosystem including actual differences in nutrient availability from localized nutrient sources and variations in macroalgal nutrient uptake mechanisms. In using a bioassay approach, factors can be standardized although this methodology may require more work than passive bioindicator surveys. My study utilized a comparison between these different methodologies and nutrient parameters to illustrate the important role variability of macroalgal response have in the interpretation of data on nutrient impact within an ecosystem. 
Table 1: Yal Ku Lagoon nutrient content (nitrogen, phosphorus, N:P) and isotopic content of Acanthophora spicifera bioassay in July 2009 and 2010. DW: dry weight. Values are means \pm SE. Significant differences between sites were assessed with ANOVAs and differences determined by pairwise comparisons. Superscripted letters indicate significant difference $(\mathrm{p}<0.01)$.

\begin{tabular}{|c|c|c|c|c|c|}
\hline & Site & $\begin{array}{c}\text { \% Nitrogen } \\
\text { (DW) }\end{array}$ & $\begin{array}{c}\text { \% Phosphorus } \\
\text { (DW) }\end{array}$ & $\mathbf{N}: \mathbf{P}$ & $\boldsymbol{\delta}^{15} \mathbf{N}(\%)$ \\
\hline \multirow{4}{*}{$\begin{array}{l}\text { July } \\
2009\end{array}$} & Initial & $0.7 \pm 0.01^{\mathrm{a}}$ & $0.02 \pm 0.00^{\mathrm{a}}$ & $38 \pm 0.2^{\mathrm{a}}$ & $4.0 \pm 0.02^{\mathrm{a}}$ \\
\hline & $400 m(n=5)$ & $0.7 \pm 0.04^{\mathrm{a}}$ & $0.04 \pm 0.00^{b}$ & $42 \pm 0.4^{b}$ & $5.3 \pm 0.04^{b}$ \\
\hline & $550 \mathrm{~m}(\mathrm{n}=6)$ & $1.3 \pm 0.03^{b}$ & $0.06 \pm 0.01^{\mathrm{c}}$ & $52 \pm 0.8^{\mathrm{c}}$ & $6.2 \pm 0.04^{\mathrm{c}}$ \\
\hline & $700 m(n=6)$ & $0.8 \pm 0.02^{\mathrm{a}}$ & $0.05 \pm 0.00^{\mathrm{b}, \mathrm{c}}$ & $39 \pm 0.3^{\mathrm{a}, \mathrm{b}}$ & $5.4 \pm 0.02^{b}$ \\
\hline \multirow{4}{*}{$\begin{array}{l}\text { July } \\
2010\end{array}$} & Initial & $0.7 \pm 0.02^{\mathrm{a}}$ & $0.04 \pm 0.00^{\mathrm{a}}$ & $42 \pm 1.2^{\mathrm{a}}$ & $4.1 \pm 0.03^{\mathrm{a}}$ \\
\hline & $0 \mathrm{~m}(\mathrm{n}=8)$ & $1.5 \pm 0.04^{b}$ & $0.06 \pm 0.00^{b}$ & $57 \pm 0.4^{b}$ & $6.0 \pm 0.04^{\mathrm{b}}$ \\
\hline & $550 \mathrm{~m}(\mathrm{n}=11)$ & $1.0 \pm 0.03^{\mathrm{c}}$ & $0.05 \pm 0.01^{\mathrm{a}, \mathrm{b}}$ & $49 \pm 0.1^{c}$ & $5.3 \pm 0.03^{\mathrm{c}}$ \\
\hline & $700 \mathrm{~m}(\mathrm{n}=10)$ & $0.8 \pm 0.03^{\mathrm{a}, \mathrm{c}}$ & $0.05 \pm 0.01^{\mathrm{a}, \mathrm{b}}$ & $39 \pm 0.2^{\mathrm{a}}$ & $2.4 \pm 0.83^{\mathrm{a}}$ \\
\hline
\end{tabular}


Figure 1: Map of Yal Ku Lagoon, Quintana Roo, Mexico

Figure 2: Percent change in nitrogen content and $\delta^{15} \mathrm{~N}$ of Acanthophora spicifera bioassay [(final-initial)/initial] x 100\% (bars indicated standard error).

Figure 3: Nitrogen content of all macroalgal species in 2009 (A) and 2010 (B). Bars indicate standard error.

Figure 4: d15N of all macroalgal species in 2009 (A) and 2010 (B). Bars indicate standard error. 


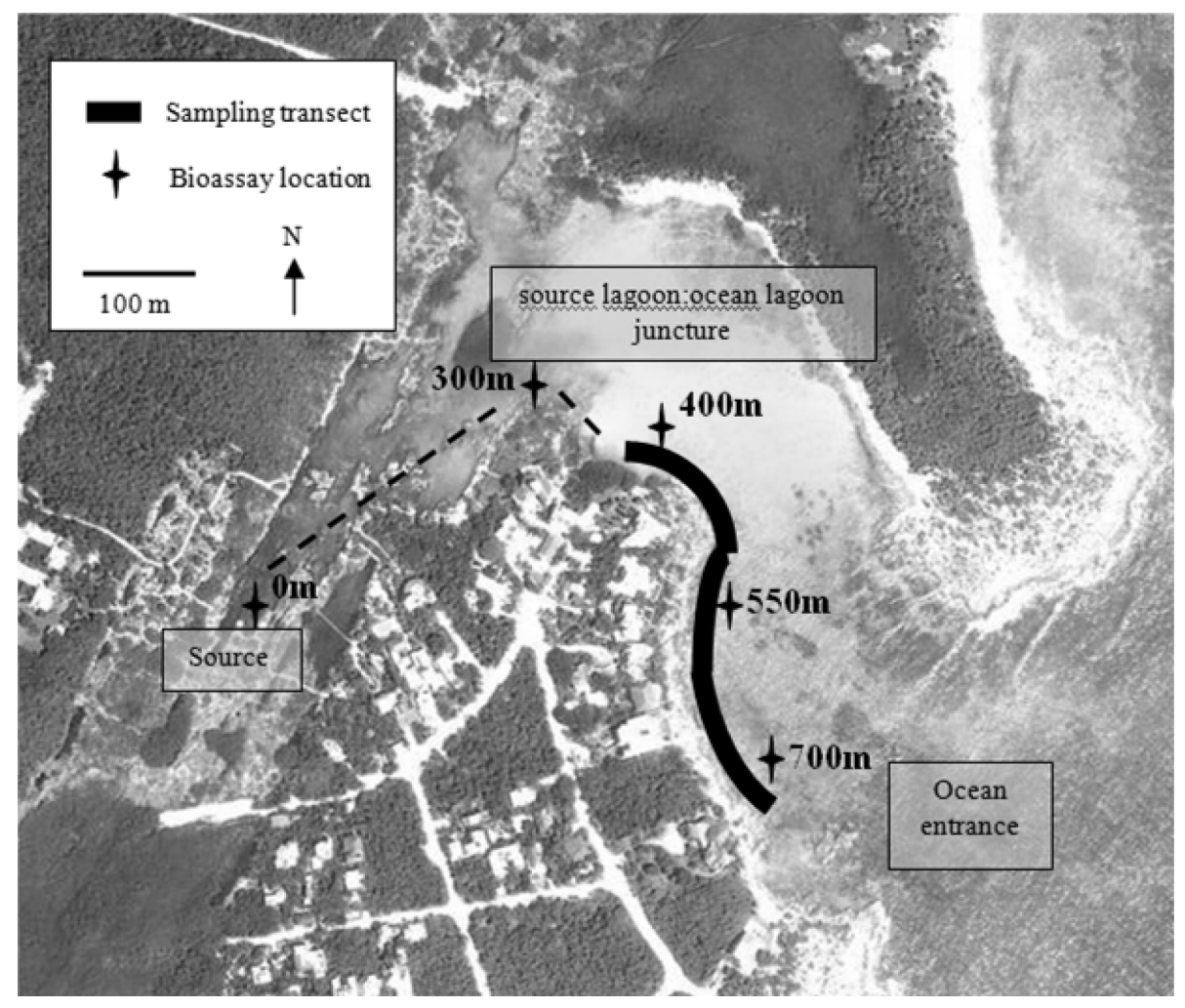




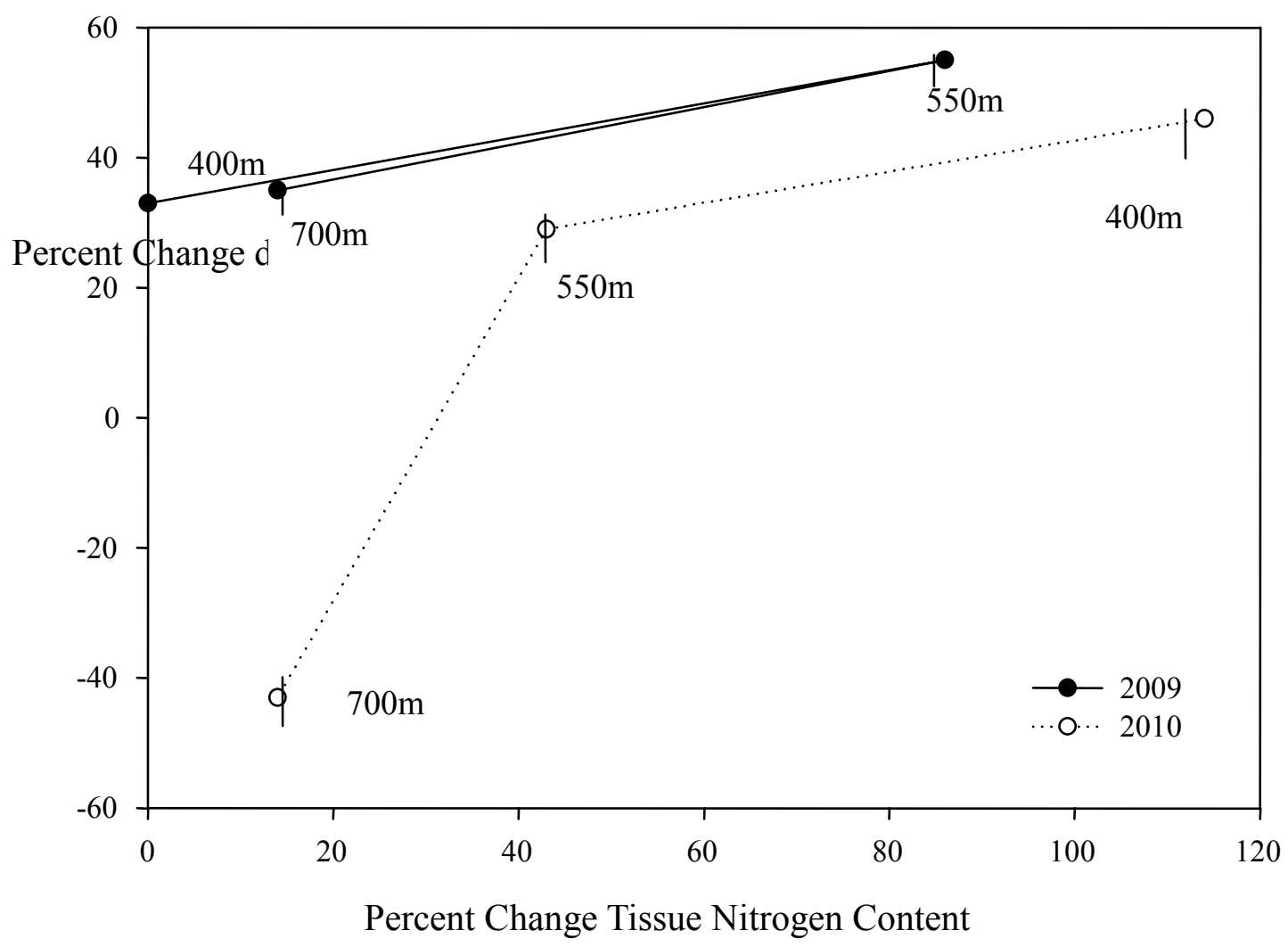




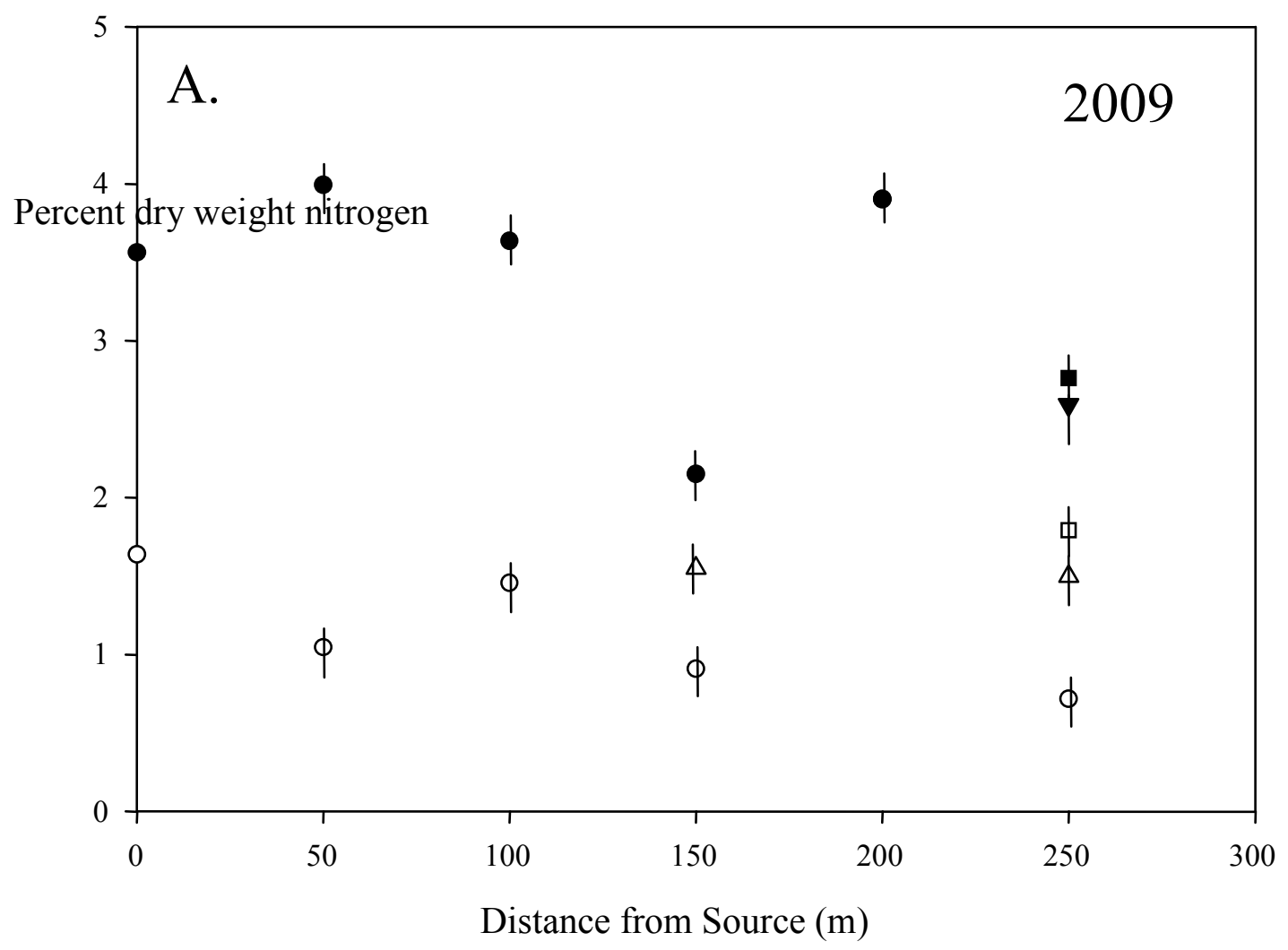

- Caulerpa

- Halimeda

$\nabla$ Udotea

$\triangle \quad$ Rhipocephalus

- Laurencia

․ Stypopodium 


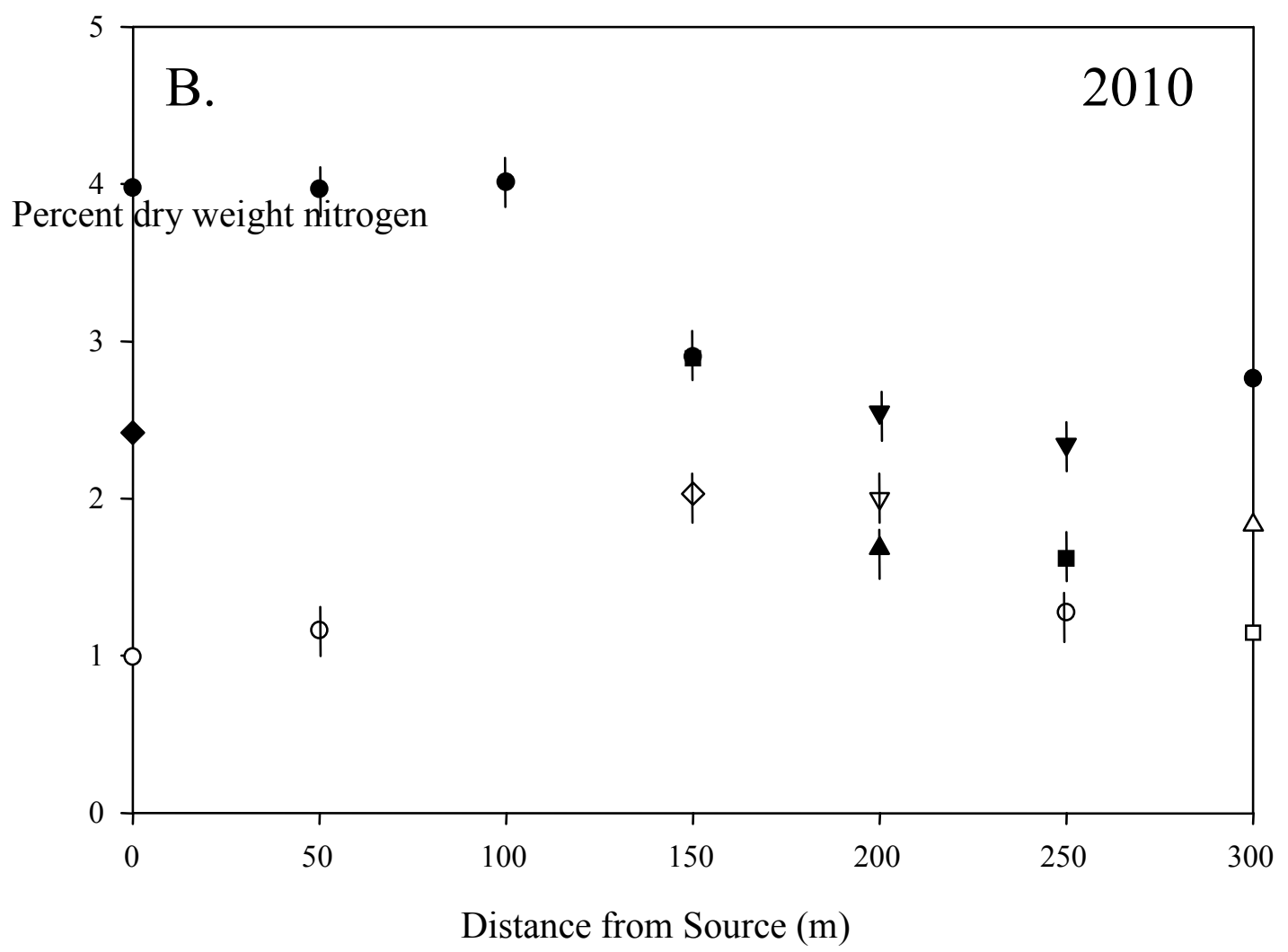

- Caulerpa

- Halimeda

$\nabla$ Udotea

$\triangle \quad$ Rhipocephalus

- Laurencia

Stypopodium

- Ulva

$\diamond \quad$ Penicillus

- Dictyota

$\nabla \quad$ Digenia 


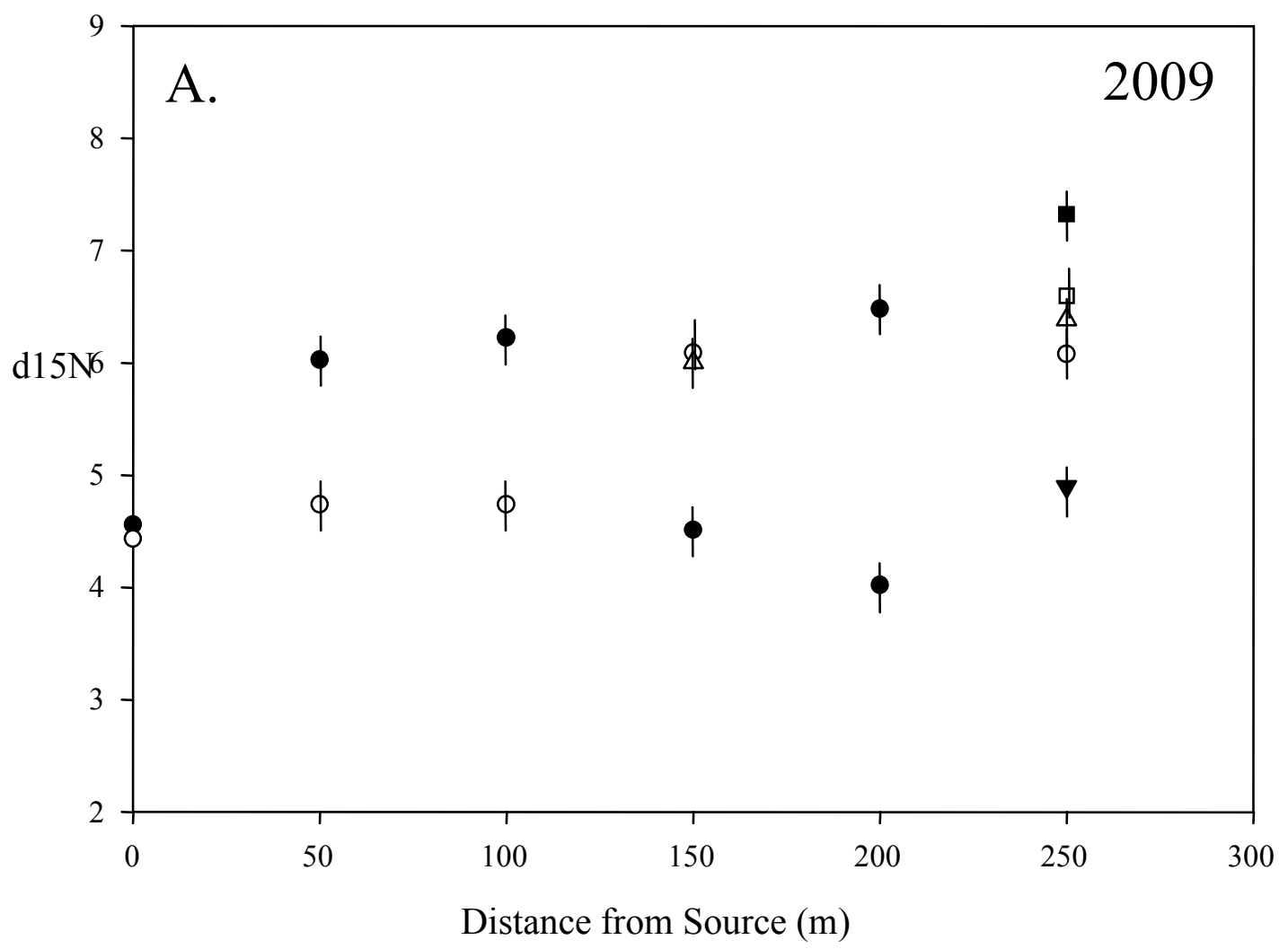

- Caulerpa

- Halimeda

$\nabla$ Udotea

$\triangle \quad$ Rhipocephalus

- Laurencia

- Stypopodium 


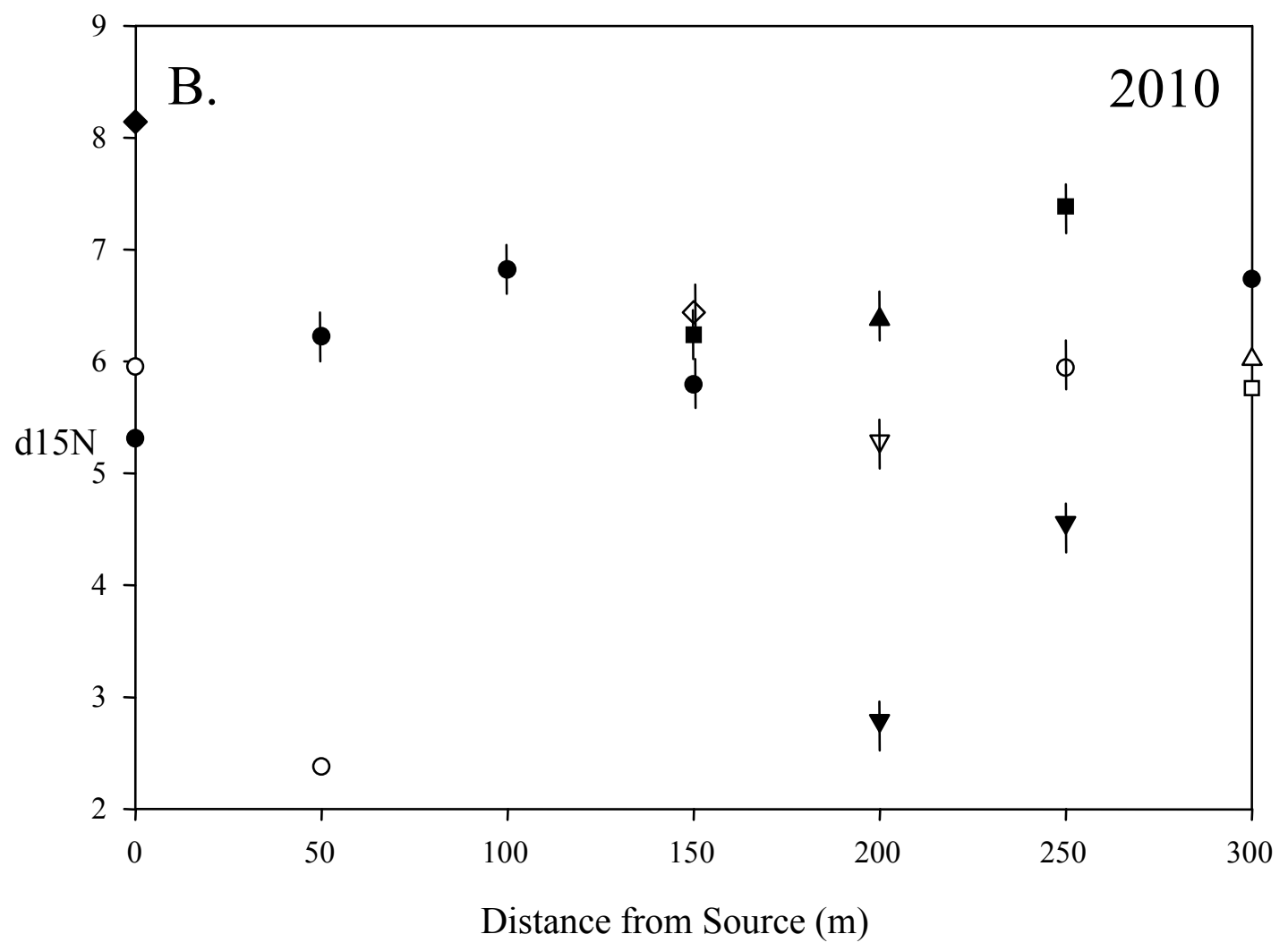

- Caulerpa

- Halimeda

$\nabla$ Udotea

$\triangle \quad$ Rhipocephalus

- Laurencia

Stypopodium

$\checkmark$ Ulva

$\diamond \quad$ Penicillus

$\triangle$ Dictyota

$\nabla \quad$ Digenia 
CHAPTER III: Morphological and physiological responses of seagrasses to grazers and their role as patch abandonment cues

Abstract

Monitoring seagrass patches grazed by the green sea turtle, Chelonia mydas, reveal that a 'giving up density' predicts patch abandonment rather than previous theories on leaf nutrient or rhizomal soluble carbohydrate content. The morphological and physiological responses (productivity, plant morphology and nutrient storage) potentially influencing seagrass recovery from grazing disturbances were monitored for one year under three different grazing scenarios (turtle grazed, fish grazed and ungrazed) in a nutrient-replete environment. Significantly less soluble carbohydrates and increased nitrogen and phosphorus content in the structurally important Thalassia testudinum were indicative of the stresses placed on macrophytes during herbivory. To determine if these physiological effects, and their impact on C. mydas nutrition and therefore patch use, were the drivers of this heterogeneous grazing behavior, patches were mapped throughout the bay and monitored over a six-month interval. The presence of ungrazed patches provided refuge for Halodule wrightii and Syringodium filiforme within the ecosystem and are important propagule source to recolonize abandoned areas. This study is the first to document the responses of a eutrophic ecosystem to these natural grazing processes and apply terrestrial theories on 'giving up density' to explain marine herbivore grazing behavior.

Introduction

Herbivores are important drivers of ecosystem dynamics (Valentine \& Duffy 2006, Heck \& Valentine 2007) and seagrass productivity (Zieman et al. 1984, Valentine 
et al. 1997), reducing canopy cover and freeing space for competitive interactions between macrophytes (Heck \& Valentine 2006). In high nutrient environments, macroalgal blooms increase the sensitivity of seagrasses to grazing as light availability affects carbohydrate storage in rhizomes and therefore the energy available to compensate for grazing disturbances (Macia 2000, Valentine et al. 2000) or higher summer productivity (Lee \& Dunton 1997). Studies considering herbivores in conjunction with eutrophication are of particular importance as coastal ecosystems worldwide are increasingly impacted by anthropogenic disturbances (Waycott et al. 2009) and interactions of grazers with nutrient-replete systems becomes more common. Cultivation grazing is the process by which grazing by turtles creates patches of new leaves, optimizing food quality as new leaves have higher nutrient content than old leaves (Bjorndal 1980, Aragones et al. 2006). The drivers behind the creation of these grazing patches, particularly the cues for herbivores to abandon a grazing patch in favor of a new patch, are not well known. Thayer et al. (1984) hypothesized that decreases in aboveground nutrient content precede bed collapse, but more recent studies suggest otherwise (Moran \& Bjorndal 2005, 2007). An alternative theory proposed by Fourqurean et al. (2010) as an extension on research by Dawes et al (1979), suggests that rhizomal soluble carbohydrates may decrease prior to seagrass bed abandonment. These reductions result in low rates of productivity and decreased biomass from thinning leaves, cueing herbivore abandonment. In addition, indices of shoot density, blade width and leaf growth are also used as early indications of chronic stress (Zieman et al. 1984, Lee \& Dunton 1997, Lal et al. 2010). These may be visual cues to induce abandonment and represent a 'giving up density' corresponding to a harvest rate that balances the 
associated metabolic costs of foraging (Brown 1988). Giving Up density theory extends the optimal foraging theory and includes balancing the harvest rate to metabolic costs, predation risk and missed opportunity costs of not engaging in alternative activities. While this theory has never been applied to marine herbivores, it may be an alternative to the theory of rhizomal soluble carbohydrate cues. No studies have monitored these physiological parameters important to seagrass recovery and growth in natural rather than simulated grazed seagrass beds (Moran \& Bjorndal 2005, Kuiper-Linley et al. 2007, Moran \& Bjorndal 2007) as they are abandoned by green sea turtles in order to elucidate patterns and cues.

My study was designed to evaluate the effect of different types of herbivory (fish and turtle) on morphological and physiological characteristics of seagrasses and which of the monitored characteristics may cue patch abandonment by green sea turtles as patch dynamics in the entire seagrass bed are monitored over time. I predict that grazed patches will have higher nutrient content (carbon, nitrogen and phosphorus) in aboveground leaf tissue than ungrazed patches, regardless of herbivore presence. I predict that summer nutrient content of aboveground biomass will be lower than winter following the hypothesis that plants increase rhizomal soluble carbohydrate storage during optimal summer growing conditions, even in a nutrient replete environment. Should soluble carbohydrate content be the cue to C. mydas patch abandonment, I predict that patches abandoned will have significantly lower soluble carbohydrates than patches remaining grazed. I hypothesize the paucity of storage in belowground nutrient reserves will cause leaf thinning and decreased productivity, the mechanism cueing herbivore 
patch abandonment. Should a giving up density be the cue, I would predict that patches with the lowest biomass, as measured through the leaf area index, will be abandoned. Methodology

Study site

Akumal ("Place of the Turtles" in Mayan) is located in Quintana Roo, Mexico on the Yucatan Peninsula along the Caribbean Sea (Latitude: $20^{\circ} 23^{\prime} 45^{\prime \prime} \mathrm{N}$ Longitude: $87^{\circ}$ 18 '52” W). Akumal Bay is the northern 400 meter portion of a $2 \mathrm{~km}$ half moon-shaped lagoon connected to Jade Bay and South Akumal Bay. A barrier reef exists $300 \mathrm{~m}$ offshore and variable-sized patch reefs are sparsely distributed throughout the entire lagoon. Highly porous, karstic geology delivers terrestrially-derived nutrients into the coastal zone through submarine groundwater discharge (Mutchler et al. 2007). Measurements of nitrogen, phosphorus and isotopic content of macrophytes, in addition to high epiphyte loads, indicate the high availability of anthropogenically derived nutrients to this ecosystem (Baker et al. 2007, Mutchler et al. 2007, Metcalfe et al. 2011). Seagrass herbivores include the green sea turtle Chelonia mydas and near the interspersed patch reefs, members of the family Scaridae (parrotfish) and Acanthuridae (surgeonfish). Seagrass beds consist of T. testudinum, H. wrightii and Syringodium filiforme with few intermixed macroalgae typified by calcareous Chlorophytes (e.g., Halimeda, Udotea) and calcareous Rhodophytes (e.g,. Neogoniolithon).

\section{Seagrass response}

To determine the species specific response of seagrass to herbivory, physiological responses were monitored in grazed and ungrazed patches in the seagrass beds. Distinct regions exist where seagrass beds have been grazed (by turtle or fish) or not grazed 
(Figure 1), and within these regions small cages (20 cm diameter) were placed for six days at a time during two distinct growing seasons (winter and summer) to sample productivity, leaf morphology, tissue nutrients and soluble carbohydrates. These cages were not intended to be experimental exclosures; rather, they allowed us to measure the production of material in the short-term without having biomass lost to fish or turtle grazers. Cages were deployed on two separate occasions during each season and samples were pooled within season after statistical analysis determined there was no significant difference between deployments within each patch (Student's t-test, $\mathrm{p}=0.897$ ). Areas targeted as fish grazed were surrounding a $50 \mathrm{~m}^{2}$ patchreef within the same seagrass beds where turtle grazing occurred. Fish herbivory was confirmed by the patterns of bite marks on leaves, which were indicative of parrotfish grazing. Cages were created with vinyl-coated hardware mesh (ca. $1 \mathrm{~cm}$ mesh) and four $3 \mathrm{~mm}$ diameter stakes secured the cage into the substrate.

To measure productivity and morphometrics within these cages, all T. testudinum blades were punched using a modified leaf marking technique (Zieman 1974, Fourqurean et al. 2001). At the end of six days, aboveground and belowground biomass was collected for all seagrass species present from which to measure carbon, nitrogen, phosphorus and soluble carbohydrates. Six randomly selected shoots of T. testudinum were measured for length, width and elongation rate ( $\mathrm{mm} / \mathrm{shoot} /$ day), from which elongation area (width $\mathrm{x}$ length of new growth at base of leaf) was calculated. All seagrass samples were cleaned of epiphytes, dried to a constant weight at $60^{\circ} \mathrm{C}$ and ground to a fine powder using a mortar and pestle. Samples were analyzed in duplicate for carbon and nitrogen content using a $\mathrm{CHN}$ analyzer and for phosphorus using dry- 
oxidation acid-hydrolysis extraction followed by colorimetric analysis. Dry weight elemental content was calculated as (mass of element/dry weight of sample) x 100\%. Rhizome tissue for all species was cleaned of adhering sediments, dried to a constant weight at $60^{\circ} \mathrm{C}$ and ground to a fine powder using a mortar and pestle. Because of the smaller size and paucity of $H$. wrightii and $S$. filiforme rhizomes, samples were pooled from three cages to provide an adequate amount of sample material. Samples were analyzed for soluble carbohydrates using the seagrass tissue adaptation (Lee \& Dunton 1997) to the MBTH (3-methyl-2-benzothiazolinone hydrazone hydrochloride) method (Pakulski \& Benner 1992).

In order to test for the hypothesized differences between herbivory patches and seasons on nutrient content, carbohydrate content and growth rates, a randomized complete block ANOVA was used for morphometric and productivity data, where shoots within cage were nested within combinations of patch (fish grazed, turtle grazed, ungrazed) $\mathrm{x}$ season (winter, summer). Data were analyzed to establish they conformed to all normality assumptions. Differences among patches for all seagrass species were determined through Least Squares Difference pairwise comparisons with Bonferroni corrected significance levels (0.008). Because of the variability in presence of $H$. wrightii and S. filiforme in grazed cages, sample sizes varied between patches and seasons. Therefore, to test for differences between herbivory patches and between seasons, nutrient content and soluble carbohydrate data were analyzed via three-way ANOVA (T. testudinum), two-way ANOVA (S. filiforme) or via a student's t-test or Mann-Whitney nonparametric test $(H$. wrightii), depending on how the data met normality assumptions. No S. filiforme was collected during the winter in the fish grazed 
patch and no $H$. wrightii was collected in the fish (either season) or turtle grazed (winter season) patches.

\section{Patch dynamics}

To monitor changes in seagrass patch location and seagrass morphological and physiological changes over time in relation to changes in patch designation (grazed and ungrazed), patch locations in the seagrass ecosystem were tracked using belt transects. These transects were established between pre-existing navigational buoys in Akumal Bay initially (January 2011) and six months later (June 2011). The belt transects differed in length and cardinal ordination, and covered a combined length of 860 meters within the northern portion of Akumal Bay where sea turtles are present in the highest densities (authors' pers obs). All surveys were completed by the same diver in order to minimize any confounding errors in patch differentiation. Patches were labeled as grazed when leaf apexes were incomplete and seagrass blade length was $5 \mathrm{~cm}$ or less from the blade sheath junction. Ungrazed patches were those with seagrass blade length greater than $5 \mathrm{~cm}$ and complete apexes. A modified Braun-Blanquet (BB) index was used to calculate abundance for each macrophyte present (Fourqurean et al. 2001) within a $0.25 \mathrm{~m}^{2}$ plot within each patch. For each macrophyte BB score, 1 indicated coverage less than $5 \%$ of the plot, 2 indicated 5-25\% cover, 3 indicated $25-50 \%$ cover, 4 indicated $50-75 \%$ cover; and 5 indicated $75-100 \%$ cover. The presence of a different patch was recorded when grazing status (grazed or ungrazed) or when BB score differed from adjacent patches.

Braun-Blanquet scores were converted to abundances using the mean abundance within each score (e.g. 2.5\% cover for score 1, 87.5\% cover for score 5) and then averaged across similarly designated patches (e.g., all grazed patches). Mean abundances 
are presented for all grazing statuses during both surveys for comparisons between surveys. A Student's t-test was used to test for differences between grazed and ungrazed seagrass abundances as no data was available to determine newly grazed or abandoned status during the initial time period. An ANOVA was used to test for differences in species abundance among patch status (ungrazed, grazed, abandoned, newly grazed) within the second sampling after examination of standardized residuals showed the data conformed to all normality assumptions. Within each patch, epiphyte presence/absence, grazing status (blade apex complete or incomplete) of T. testudinum and seagrass blade length for all species was recorded. After the second survey patches labeled ungrazed had been ungrazed for six months or more while abandoned patches were recently ungrazed (less than six months since being grazed). Following the second survey, a Student's t-test was used to test for differences in proportions of each transect in each status between sampling events.

At 15 randomly chosen patches within the study area, aboveground and belowground biomass of $T$. testudinum was collected to determine the change in response variables between sampling intervals as a function of patch status. Six randomly selected shoots of T. testudinum were measured for length and width and cleaned of epiphytes, dried to a constant weight at $60^{\circ} \mathrm{C}$ and ground to a fine powder using a mortar and pestle. Samples were processed for carbon, nitrogen, phosphorus and soluble carbohydrates using the same methods as for cage samples. An ANOVA was used to test for hypothesized differences in all parameters (width, carbon, nitrogen, phosphorus, soluble carbohydates) among patch status in the second survey (remain ungrazed, remain grazed, abandoned) after examination of standardized residuals showed the data conformed to all 
normality assumptions. A Student's t-test was used to test for differences in initial survey data between patches designated during the second survey as grazed and abandoned. Means are presented for each of the three statuses in the initial survey for comparisons between surveys. None of the patches sampled changed from an ungrazed to a grazed status during the sampling interval.

Results

Seagrass response

Ungrazed patches had the widest Thalassia testudinum blades (ANOVA F = 12.06, $\mathrm{p}<0.001$ ) with fastest elongation rate (ANOVA $\mathrm{F}=16.99, \mathrm{p}<0.001)$ and largest new growth area (ANOVA F $=10.22, \mathrm{p}=0.002)$ when compared to fish and turtle grazed patches (Figure 2 and 3). The difference was greater in the summer months and significantly higher in ungrazed patches compared to grazed patches regardless of grazer identity in both seasons ( $\mathrm{p}<0.001$ for all three parameters). Fish grazed and turtle grazed patches were significantly different from each other in width during the winter $(p$ $<0.001)$, but were not significantly different for other parameters or within the same patch between seasons. Grazed shoots had a maximum of three leaves while ungrazed shoots had a maximum of six leaves. Fish grazed leaves appeared less pigmented and curled. All three species of seagrass were present in ungrazed patches while only $T$. testudinum and occasionally S. filiforme were present in grazed patches.

Ungrazed patches of T. testudinum had lower nitrogen and phosphorus content than turtle and fish grazed patches in both seasons (Figure 4). Carbon content was not significantly different from turtle or fish grazed patches in the winter or summer, respectively ( $p=0.178$ and 0.912 , respectively). Differences between C:N:P ratios 
among patches were the result of nitrogen and phosphorus differences as well as temporal decreases in nutrient availability. Ungrazed patches changed winter (542:29:1) to summer (635:31:1), fish grazed patches changed winter (446:32:1) to summer $(544: 35: 1)$ and turtle grazed patches changed winter (388:30:1) to summer (426:30:1). Soluble carbohydrates were significantly higher in the ungrazed patches for both seasons and were significantly higher in summer compared to winter for all three patches (Figure 4).

Similar significant differences to those of T. testudium were found in Syringodium filiforme, where ungrazed patches had significantly less nitrogen and phosphorus content than turtle grazed patches (Figure 5, sample size was too small to test for differences to fish grazed patches). For Halodule wrightii, significant differences between ungrazed and turtle grazed patches in the winter occurred only in nitrogen and phosphorus content (Figure 6, Patch Mann-Whitney $\mathrm{p}=0.010$ for both). There was significantly higher carbon, nitrogen and phosphorus content in winter compared to summer in the ungrazed patches, similar to the trend found in T. testudinum and $S$. filiforme. Soluble carbohydrates of rhizomes were significantly higher in ungrazed patches than turtle grazed patches (t-test $\mathrm{p}<0.001$ ), similar to T. testudinum. Grazed shoots had a maximum of three leaves while ungrazed shoots had a maximum of seven leaves.

\section{Patch dynamics}

The majority of seagrass patches surveyed during the initial survey were ungrazed $(63 \%)$ with epiphyte present while the remaining patches were grazed and epiphytes were absent. The percent of ungrazed patches did not significantly change during the second survey (Student's t-test, $\mathrm{p}=0.911$ ) while significant reductions in grazed patches occurred (Student's t-test, $\mathrm{p}<0.003$ ). From the initial $318 \mathrm{~m}$ of grazed patches, $27 \%$ 
continued to be grazed while $73 \%$ were abandoned in the second survey (Figure 7). From the initial $542 \mathrm{~m}$ of ungrazed patches, $97 \%$ remained ungrazed while $3 \%$ were newly grazed in the second survey. During initial surveys, ungrazed patches had significantly higher abundances of all three seagrass species than grazed patches (t-test $\mathrm{p}$ $<0.001$, Table 1).

In the second survey, comparisons could only be made between ungrazed, grazed and abandoned patches as sample size of newly grazed patches was too small $(n=1)$ for statistical comparison. Ungrazed patches had the highest abundance of T. testudinum and S. filiforme than grazed and abandoned patches (ANOVA $\mathrm{p}=0.015$ and $\mathrm{p}=0.037$, respectively) while $H$. wrightii abundance was highest in abandoned patches (ANOVA p $=0.008)$ and increased significantly from initial to second survey (t-test $\mathrm{p}<0.001) . H$. wrightii was also significantly different from both ungrazed and continually grazed plots. S. filiforme and T. testudinum abundance did not significantly change for abandoned patches from initial to second survey $(\mathrm{t}$-test $\mathrm{p}=0.912)$. There were two new species of macroalgae within the one abandoned plot that had macroalgae but because of the small sample size, significant differences could not be determined. In the one newly grazed patch, there was one less seagrass species present but small sample size did not allow statistical comparisons.

Within the fifteen patches of $T$. testudinum sampled for nutrients, soluble carbohydrates and morphometrics during the initial survey, ungrazed patches had significantly lower nitrogen and phosphorus content (t-test $\mathrm{p}$-value $<0.001$ for both parameters) and significantly higher soluble sugar content $(\mathrm{t}$-test $\mathrm{p}$-value $=0.044)$ than grazed patches, similar to those results found in the cages. During the second survey, 
carbon content and nitrogen:phosphorus were not significantly different between patch status (ungrazed, grazed and abandoned, Figure 8). Phosphorus content, soluble carbohydrates and carbon:phosphorus were not significantly different between abandoned and ungrazed patches while nitrogen content and carbon:nitrogen were not significantly different between abandoned and grazed patches. Therefore, I detected no differences in carbon, nitrogen, phosphorus or soluble carbohydrates in Thalassia testudinum that seemed to serve as cues for abandonment of grazed plots. Plotting leaf length and width for each patch status illustrated a clumping of patches prior to abandonment and a distinct shift in these parameters following abandonment (Figure 9). Leaf biomass was calculated (length $\mathrm{x}$ width $\mathrm{x} 2$ ) and multiplied by the BB density score to incorporate both biomass and density in the determination of a threshold at which patches may be abandoned (Figure 10).

Discussion

My study determined that in seagrass beds with high nutrient availability, patches grazed by fish or turtles had higher nutrient content in aboveground tissue and depleted belowground energy reserves than those patches that were ungrazed. Herbivore-specific responses of Thalassia testudinum in grazed patches were reflected in tissue nutrient content ratios and leaf morphology, where patches grazed by fish had significantly narrower leaves and significantly higher nutrient content than those patches grazed by turtles. The Halodule wrightii and Syringodium filiforme present in the ungrazed beds may provide a source for recolonization by these species once patches are abandoned. I determined that seagrass patches abandoned in the second survey did not contain the lowest content of carbon, nitrogen, phosphorus and soluble carbohydrate, contrary to 
predictions. Instead, my data suggest that a 'giving up density' similar to found in terrestrial ecosystems is the mechanism by which patches are abandoned.

\section{Herbivory in a nutrient-replete seagrass ecosystem}

The relative physiological and morphological effects (productivity, tissue nutrients and soluble carbohydrates) of grazing on macrophytes were similar to those previously measured from simulated grazing or exclosure experiments in sites with lower nutrient availability (Moran \& Bjorndal 2005, 2007, Fourqurean et al. 2010). Overall values of nitrogen and phosphorus content of T. testudinum in this study (maximum 3.4 and 0.26 percent dry weight, nitrogen and phosphorus respectively) were higher than those found in Bermuda (maximum 2.5 and 0.15 percent dry weight, nitrogen and phosphorus, respectively, see Fourqurean et al. 2010). High nutrient availability shifted $\mathrm{N}: \mathrm{P}$ ratios in all patches towards the taxon specific Redfield ratio of 30:1 (Duarte 1992). During the summer, C:N:P ratios were higher as more carbon was fixed in all three patches and in winter only turtle grazed patches were significantly below the taxon specific Redfield ratio for C:P (Duarte 1992).

Contrary to the typical response of macrophytes to the increased favorable growing conditions in the summer (Lee \& Dunton 1997) and as recorded in the ungrazed patches during this study, neither fish nor turtle grazed patches had higher productivity in summer compared to winter. Leaf widths of fish grazed (4.9-5.4mm) and turtle grazed $(5.0-5.9 \mathrm{~mm})$ patches in this study were narrower than some other studies on grazing (6.3 $-6.3 \mathrm{~mm}$; Zieman et al. 1984) but not as narrow as other published studies $(5.6-6.3 \mathrm{~mm}$, Moran \& Bjorndal 2005; $3.3-4.7 \mathrm{~mm}$, Williams 1988; $1.4-3.0 \mathrm{~mm}$, Fourqurean et al. 2010). Differences in leaf widths further emphasizes the detrimental effects of high 
grazing to seagrass photosynthetic leaf tissue and rhizomal storage morphological and physiological parameters, which are necessary components to consider for seagrass recovery and survival. My study is the first to record these parameters in response to grazing behavior in a nutrient-replete environment.

Smaller sample sizes for Syringodium filiforme and Halodule wrightii limited the determination of significant differences in nutrient and soluble carbohydrate content between patches but their absence in grazed patches may indicate herbivore preference (Armitage \& Fourqurean 2006). The absence of certain species may also indicate a lower tolerance to these repeated or prolonged grazing behaviors as they are unable to recover sufficiently to remain in the ecosystem (Kuiper-Linley et al. 2007). The lower soluble carbohydrate in the ungrazed S. filiforme during the winter may decrease the ability of this species to recover from grazing. Larger species with thicker rhizomes, such as $T$. testudinum, may also be better at translocating their stored carbohydrates longer distances and are therefore better able to compensate for loss than those species with thinner rhizomes, e.g., H. wrightii and S. filiforme (Marba et al. 2006). The reduced productivity and amount of leaves for all three species when compared to ungrazed leaves reflects a significant decrease in aboveground biomass and increases the plant's reliance on belowground biomass as a energy reserve (Williams 1988). As these reserves are depleted to replace leaves lost to grazers, the lower soluble carbohydrate content of the rhizomes reduces the ability of the plant to counter prolonged or future disturbances until the reserves can be replaced (Thayer et al. 1984, Kuiper-Linley et al. 2007, Moran \& Bjorndal 2007). More importantly, considering this relationship was found at a eutrophic study site further indicates that high nutrient availability cannot counter the biomass loss 
caused by grazing as these macrophytes become carbon starved through similar mechanisms as those found in mesotrophic seagrass beds (Fourqurean et al. 2010). My data also support the recent relationship established between nutrient-replete environments and reduced soluble carbohydrates as seagrasses utilize available nutrients for growth rather than rhizomal storage (Campbell et al. 2012).

\section{Grazer behavior and patterns}

Over a six month interval, the location of grazed patches was largely stable, with only a small fraction of area changing status. My data indicate grazing patches were long-lived enough to affect soluble carbohydrate storage, morphology and nutrient content of seagrass leaves. As expected, during the initial survey turtle herbivory reduced seagrass abundance and canopy complexity (macrophyte species diversity and blade length and width). During the second survey, after patches were abandoned, increased leaf lengths, widths and the occurrence of pioneering species (Halodule wrightii) increased canopy complexity. The abundance of this species in recently abandoned patches is consistent with successional dynamics reported for other types of seagrass ecosystems, especially in nutrient-replete systems (Duarte 1995, Fourqurean et al. 1995). Although I cannot test statistically changes in macroalgae as a result of the small sample size, the one patch that had Udotea and Halimeda during the initial study did have a new genus, Penicillus, during the second survey. It was surprising that macroalgae was scarce throughout grazed patches, where canopy cover was decreased and competitive interactions may be favored, or in ungrazed patches, where macroalgae may potentially find refuge from selective removal by 'pruning' grazers. Slow colonization by macroalgae may be due to a limited reproductive potential into the area 
and is an interesting area for further study on macrophyte dynamics in this unique system.

Different impacts of grazers on seagrass species may also be an important determinant of primary producer distribution, as found in other studies (Armitage \& Fourqurean 2006). Fishes such as members of the family Scaridae preferentially feed on faster-growing, early successional seagrass species such as Halodule wrightii over slower-growing, climax species such as T. testudinum (Armitage \& Fourqurean 2006), thus impacting the diversity of seagrasses found within these grazed patches. Macrophyte preference is less evident for green sea turtles in the Caribbean as their diet largely consists of T. testudinum (Mortimer 1981), which may be an artifact of the lower availability and abundance of $H$. wrightii relative to other species as well as spatial variability between grazing populations and habitat types (Bjorndal 1997). This is the first study to simultaneously consider the impact of different grazing behaviors on morphological and physiological parameters important to seagrass growth and recovery (e.g., productivity, blade width).

Ungrazed portions of the seagrass bed provided refugia for $H$. wrightii and S.filiforme within the ecosystem, which may allow recolonization by these species once patches are abandoned by grazers. Similar responses have been reported after other disturbances (Armitage et al. 2011). While H. wrightii can replace T. testudinum under conditions of high nutrient availability (Fourqurean et al. 1995), if no source for $H$. wrightii propagules exists, the ecosystem could collapse to become bare sand. This study indicates that heterogeneous grazing may promote a more species-rich seagrass community in a eutrophic ecosystem. 


\section{Giving Up Density as a driver to patch abandonment}

Monitoring of patch status provided an opportunity to look at the changes in response variables (nutrient content, morphology, physiology) as a function of patch type. The driver(s) behind these changes in patch use are elusive as monitoring of Chelonia mydas patch use through time can be challenging in the field. My results did not conform to my hypothesized association to soluble carbohydrates or with the previously hypothesized driver of nutrient content. However, those patches abandoned had the smallest biomass and therefore density of leaves (Figure 5), indicating that a giving up density or a 'giving up biomass' may be the mechanism by which patches are abandoned. When a patch is composed of these much smaller leaves, the effort required by C. mydas to consume enough plant biomass to fulfill their nutritional needs far outweighs the cost and therefore induces abandonment, similar to the mechanism reported in terrestrial ecosystems (Brown 1988). This theory refers to the density of resources within a patch at the point an herbivore discontinues grazing. In this system, patch abandonment is not driven by the quality of seagrass as would be reflected in the soluble carbohydrate or nutrient content, but by the low quantity provided by the sparse, thin seagrass blades of the heavily grazed patches. This is supported by the abandonment of only those patches with leaf area/biomass less than $350 \mathrm{~mm}^{2}$. I would expect that once a patch reaches this 'abandonment threshold,' the patch will be abandoned by mesograzers in search of higher quantity yields for their grazing effort.

My research is the first to apply the 'giving up density' theory to the grazing behavior of marine herbivores. The application of this theory provides novel insight on the behavior of mesograzers and the crossover between terrestrial and aquatic theories, 
which provides a platform for additional inquiries on the behavior of other mesograzers (e.g., manatees, dugongs). While sea turtles in this study site are not at risk of predation because of the paucity of predators, Brown's original theory included predation cost.

Where predation is higher, there may be a greater risk to continued grazing when available food biomass and density are low. I therefore might predict this abandonment threshold to be at a higher density than my study site as costs of predation risk outweigh low harvest rates. The application of giving up density theory should be examined in other sites where the drivers behind patch abandonment by green sea turtles have yet to be determined and predation may be a consideration. 
Table 1: Average percent abundance of seagrass in patches within each grazing designation.

\begin{tabular}{|c|c|c|c|c|c|c|}
\hline \multirow{2}{*}{\multicolumn{2}{|c|}{ Sampling }} & \multicolumn{4}{|c|}{ Patch Status } & \multirow[b]{2}{*}{ Statistic } \\
\hline & & $\begin{array}{l}\text { Ungrazed } \\
\qquad \mathrm{n}=20\end{array}$ & $\begin{array}{c}\text { Newly } \\
\text { Grazed } \\
\mathrm{n}=1 \\
\end{array}$ & $\begin{array}{c}\text { Grazed } \\
n=6 \\
\end{array}$ & $\begin{array}{c}\text { Abandoned } \\
\qquad \mathrm{n}=11\end{array}$ & \\
\hline \multirow{2}{*}{$\begin{array}{l}\text { Thalassia } \\
\text { testudinum } \\
\text { abundance }\end{array}$} & Initial & \multicolumn{2}{|c|}{$31 \%$} & \multicolumn{2}{|c|}{$1 \%$} & $\begin{array}{c}\text { t-test } \\
\mathrm{p}<0.001\end{array}$ \\
\hline & Second & $32 \%^{\mathrm{a}}$ & $25 \%$ & $12 \%^{\mathrm{b}}$ & $10 \%{ }^{b}$ & $\begin{array}{l}\text { ANOVA } \\
\mathrm{p}=0.015\end{array}$ \\
\hline Syringodium & Initial & \multicolumn{2}{|c|}{$10 \%$} & \multicolumn{2}{|c|}{$1 \%$} & $\begin{array}{c}\mathrm{t} \text {-test } \\
\mathrm{p}<0.001\end{array}$ \\
\hline $\begin{array}{r}\text { filiforme } \\
\text { abundance }\end{array}$ & Second & $23 \%{ }^{\mathrm{a}}$ & $5 \%$ & $10 \%{ }^{\mathrm{b}}$ & $10 \%{ }^{\mathrm{b}}$ & $\begin{array}{l}\text { ANOVA } \\
\mathrm{p}=0.037\end{array}$ \\
\hline Halodule & Initial & \multicolumn{2}{|c|}{$23 \%$} & \multicolumn{2}{|c|}{$1 \%$} & $\begin{array}{c}\mathrm{t} \text {-test } \\
\mathrm{p}<0.001\end{array}$ \\
\hline abundance & Second & $22 \%{ }^{\mathrm{a}}$ & $5 \%$ & $1 \%{ }^{\mathrm{b}}$ & $31 \%{ }^{c}$ & $\begin{array}{l}\text { ANOVA } \\
p=0.008\end{array}$ \\
\hline
\end{tabular}


Figure 1: Patch differentiation as ungrazed (left) and turtle grazed (right). Note the thinner, less dense seagrass in the grazed plot with exposed sediment when compared to the denser, longer Thalassia testudinum blades in the ungrazed plot.

Figure 2: Thalassia testudinum width in all three grazing patches for both seasons winter and summer. Values are patch means \pm SE. Significant differences were assessed with a randomized complete block ANOVA and differences among patches determined through pairwise comparisons with Bonferroni corrected significance levels (0.008).

Superscripted letters indicate significant difference between patches in the same season $($ ANOVA F $=12.063, \mathrm{p}<0.001)$

Figure 3: Thalassia testudinum elongation rate and new growth area for both seasons winter and summer. Values are patch means \pm SE. Significant differences were assessed with a randomized complete block ANOVA and differences among patches determined through pairwise comparisons with Bonferroni corrected significance levels (0.008). Superscripted letters indicate significant difference among patches in the same season (Elongation rate ANOVA, $\mathrm{F}=16.993, \mathrm{p}<0.001$; New Growth Area ANOVA, $\mathrm{F}=$ $10.224, \mathrm{p}=0.002)$

Figure 4: Thalassia testudinum carbon (a), nitrogen (b), phosphorus (c) and soluble carbohydrates $(d)$. Values are patch means \pm SE. Significant differences were assessed with 3-way ANOVAs, and differences among patches determined by pairwise comparisons with Bonferroni corrected significance levels (0.008). Superscripted letters indicate significant difference among patches in the same season (corresponding to the Patch ANOVA F and p-value). Samples sizes are summer, winter: ungrazed $(12,11)$, fish grazed $(6,10)$ and turtle grazed $(12,8)$. 
Figure 5: Syringodium filiforme carbon (a), nitrogen (b), phosphorus (c) and soluble carbohydrates (d). Values are patch means \pm SE (ungrazed and turtle grazed only). Significant differences were assessed with 2-way ANOVAs and differences between patches determined by pairwise comparisons with Bonferroni corrected significance levels (0.008). Superscripted letters indicate significant difference between patches in the same season (corresponding to the Patch ANOVA F and p-value). Samples sizes are summer, winter: ungrazed $(4,11)$, fish grazed $(0,1)$ and turtle grazed $(4,8)$.

Figure 6: Halodule wrightii carbon (a), nitrogen (b), phosphorus (c) and soluble carbohydrates $(d)$. Values are patch means \pm SE (ungrazed and turtle grazed only). Significant differences between winter and summer ungrazed samples were assessed with a student's t-test. Significant differences between summer ungrazed and turtle grazed were assessed with student's t-test (t-test) or Mann-Whitney t-test (M-W), depending on normality of data from the small sample size. Samples sizes are summer, winter: ungrazed $(4,11)$, fish grazed $(0,0)$ and turtle grazed $(0,3)$.

Figure 7: Percentage of patch area in each patch status. Patches that remained ungrazed or remain grazed are the same color as those patches ungrazed or grazed.

Figure 8: Thalassia testudinum within the monitored patches carbon (a), nitrogen (b), phosphorus (c) and soluble carbohydrates (d). Values are patch means \pm SE. Significant differences were assessed with 3-way ANOVAs, and differences among patches determined by pairwise comparisons with Bonferroni corrected significance levels (0.008). Superscripted letters indicate significant difference among patches during the second survey only (corresponding to the Patch ANOVA F and p-value). 
Figure 9: Scatterplot of Thalassia testudinum width by length for initial survey (A) and second survey (B) of patches at three different grazing statuses.

Figure 10: Leaf area biomass and density $\left(\mathrm{mm}^{2} / \mathrm{m}^{2}\right)$ by patch type. 


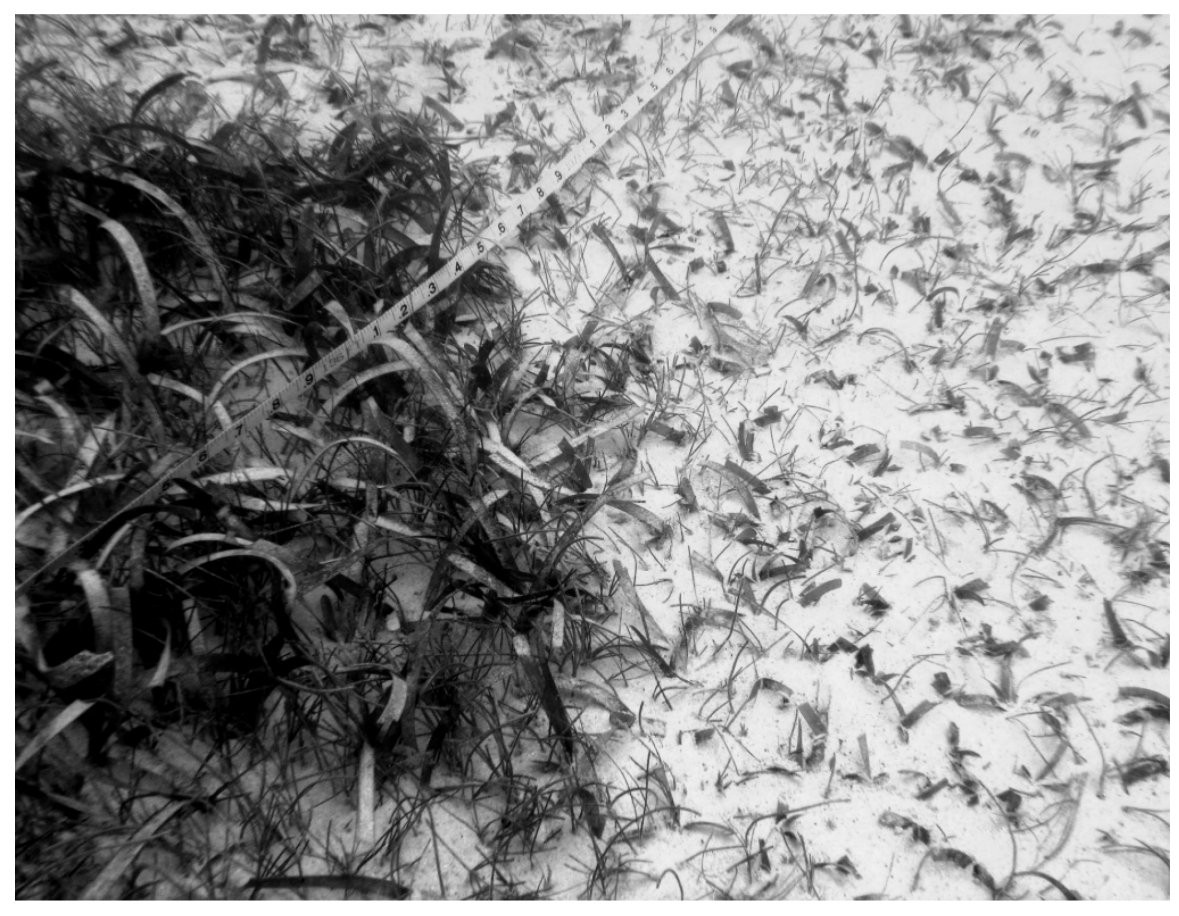




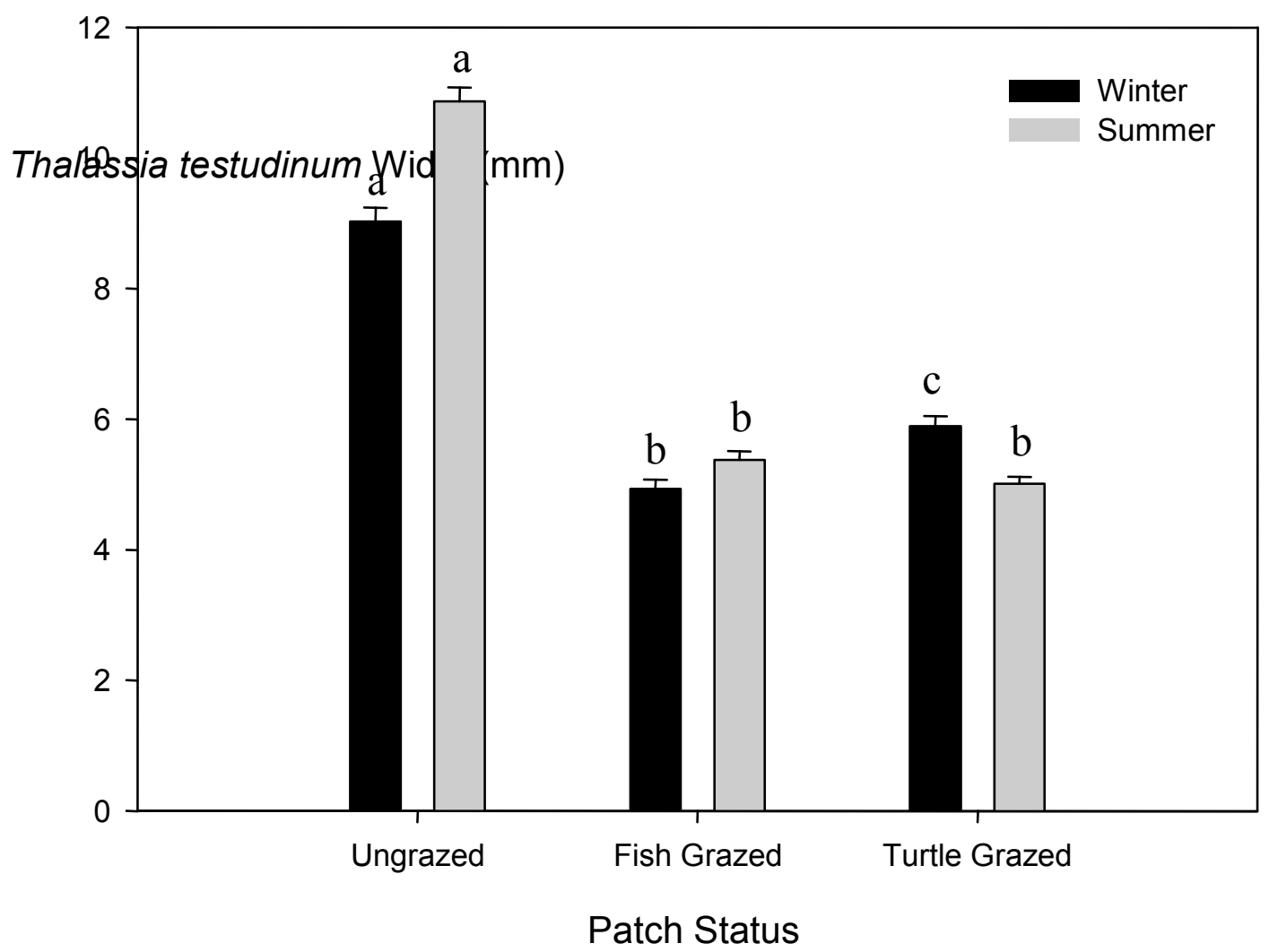




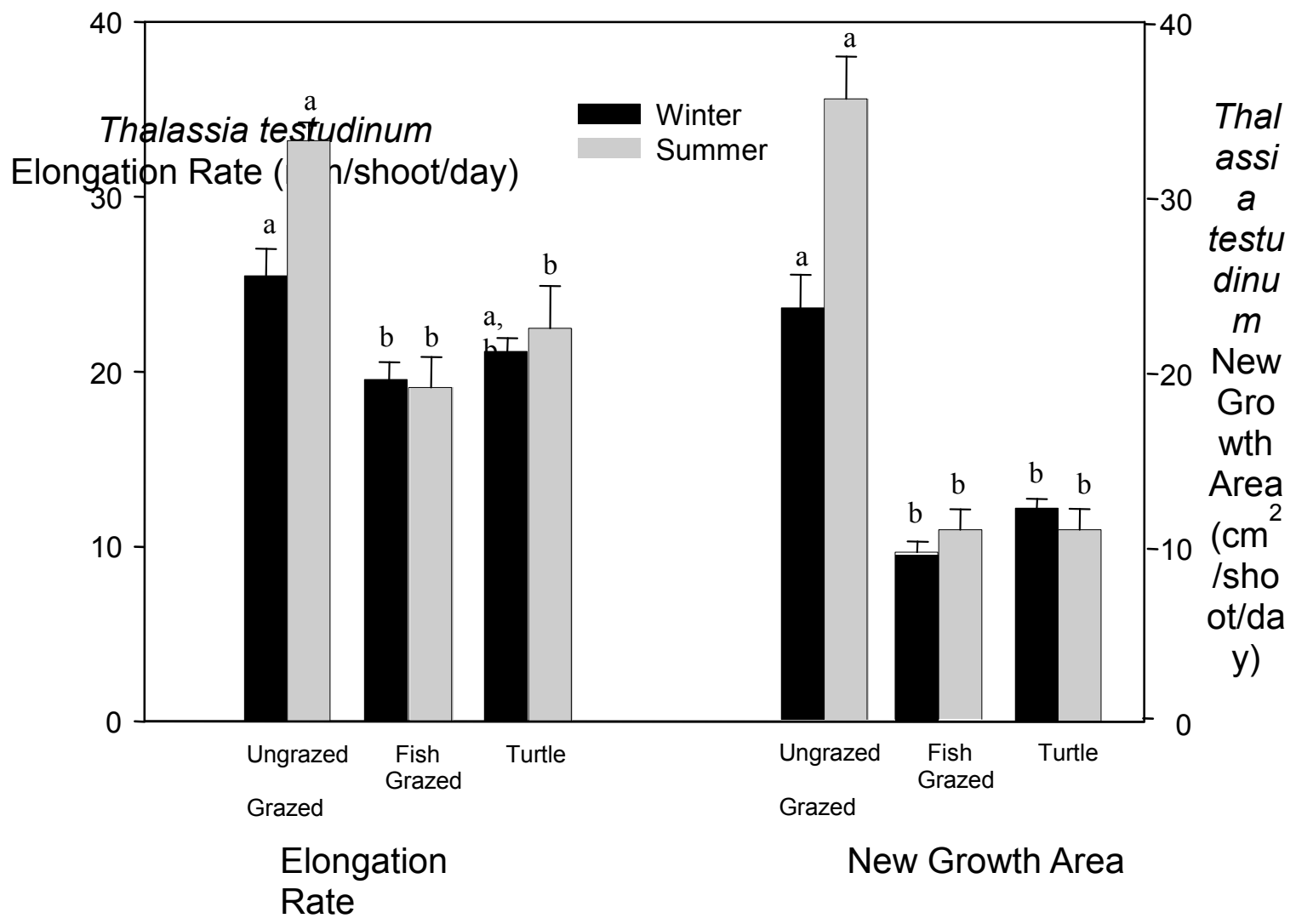


50

a.

Winter

Summer

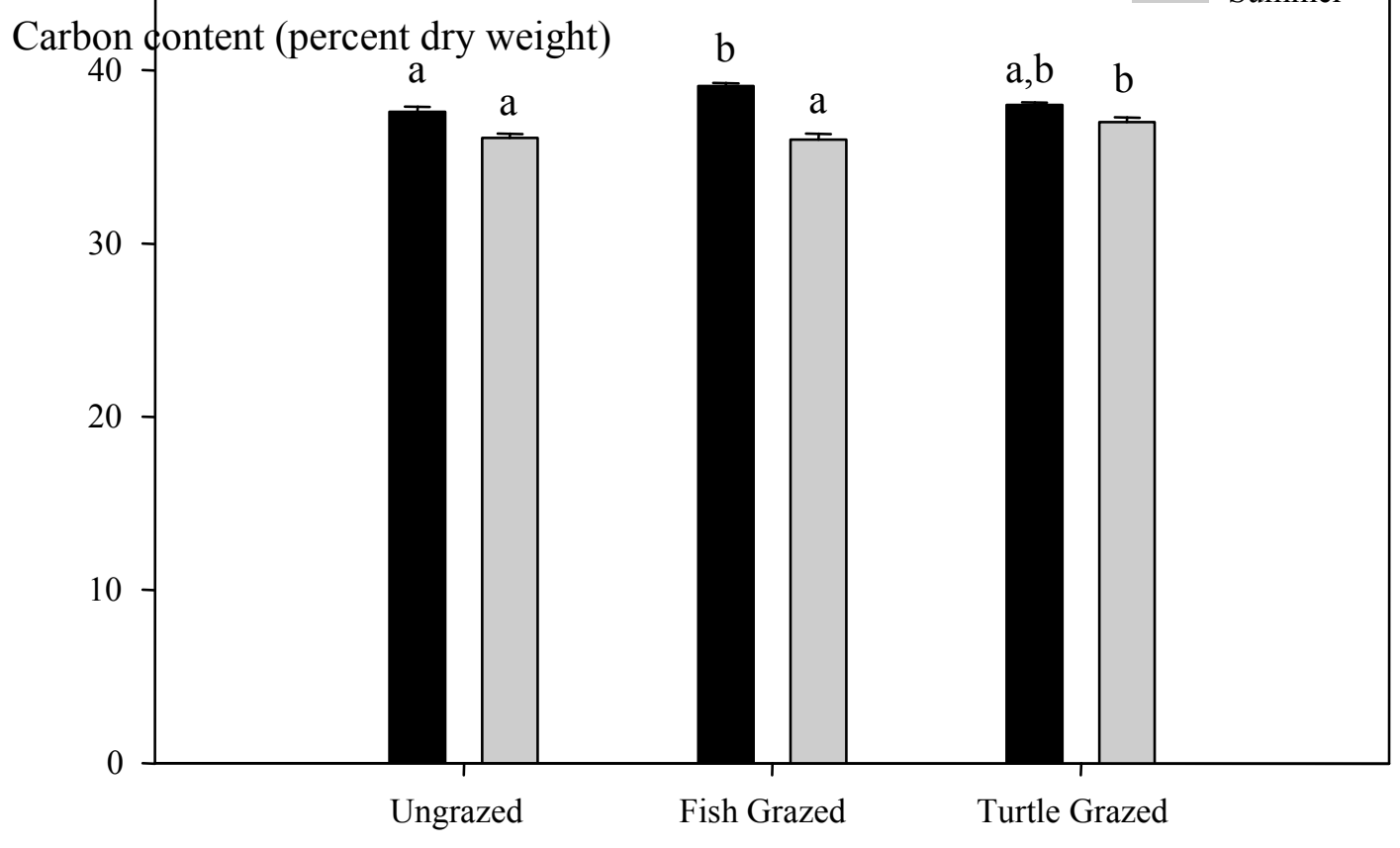

Patch Status

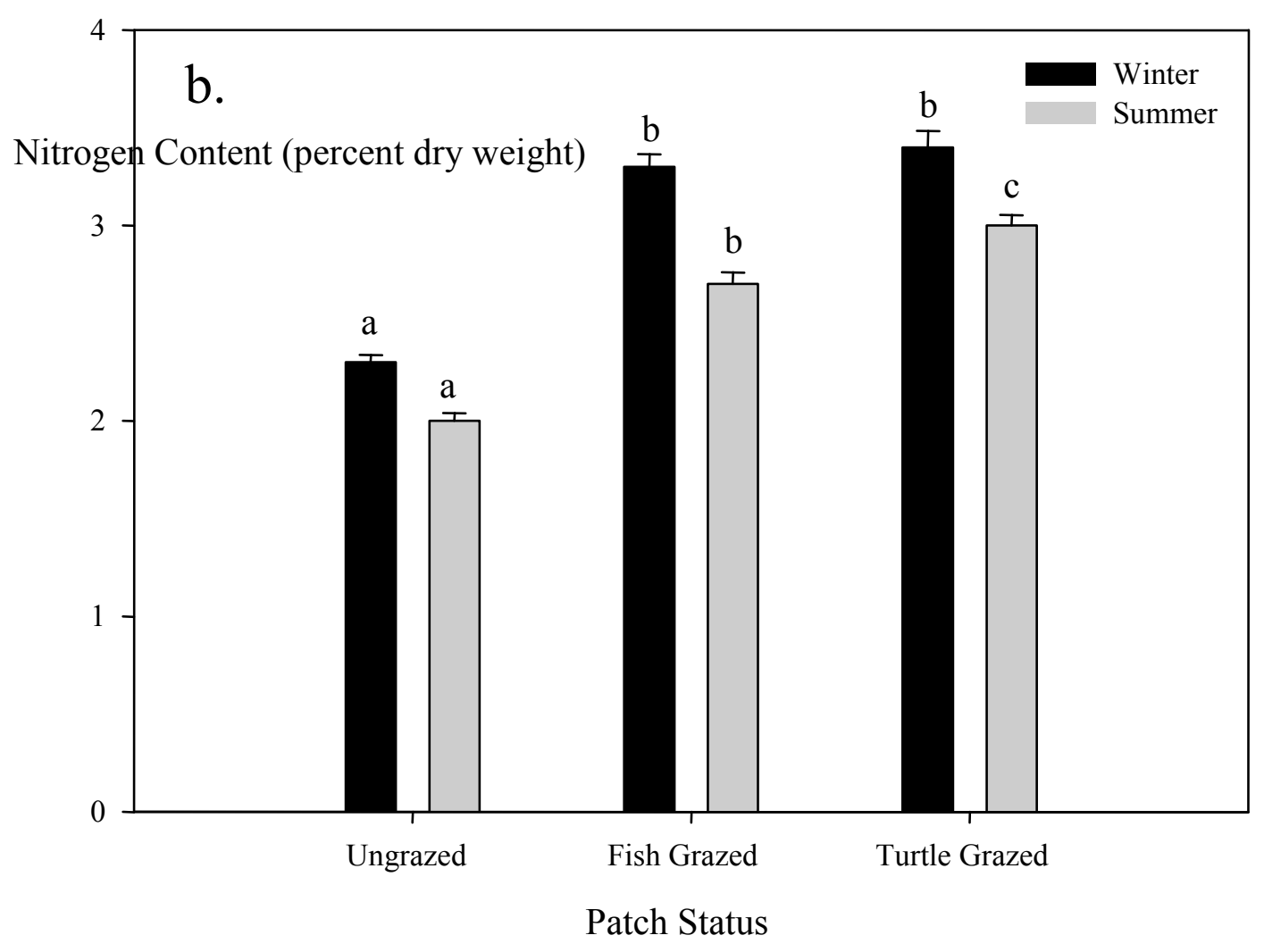



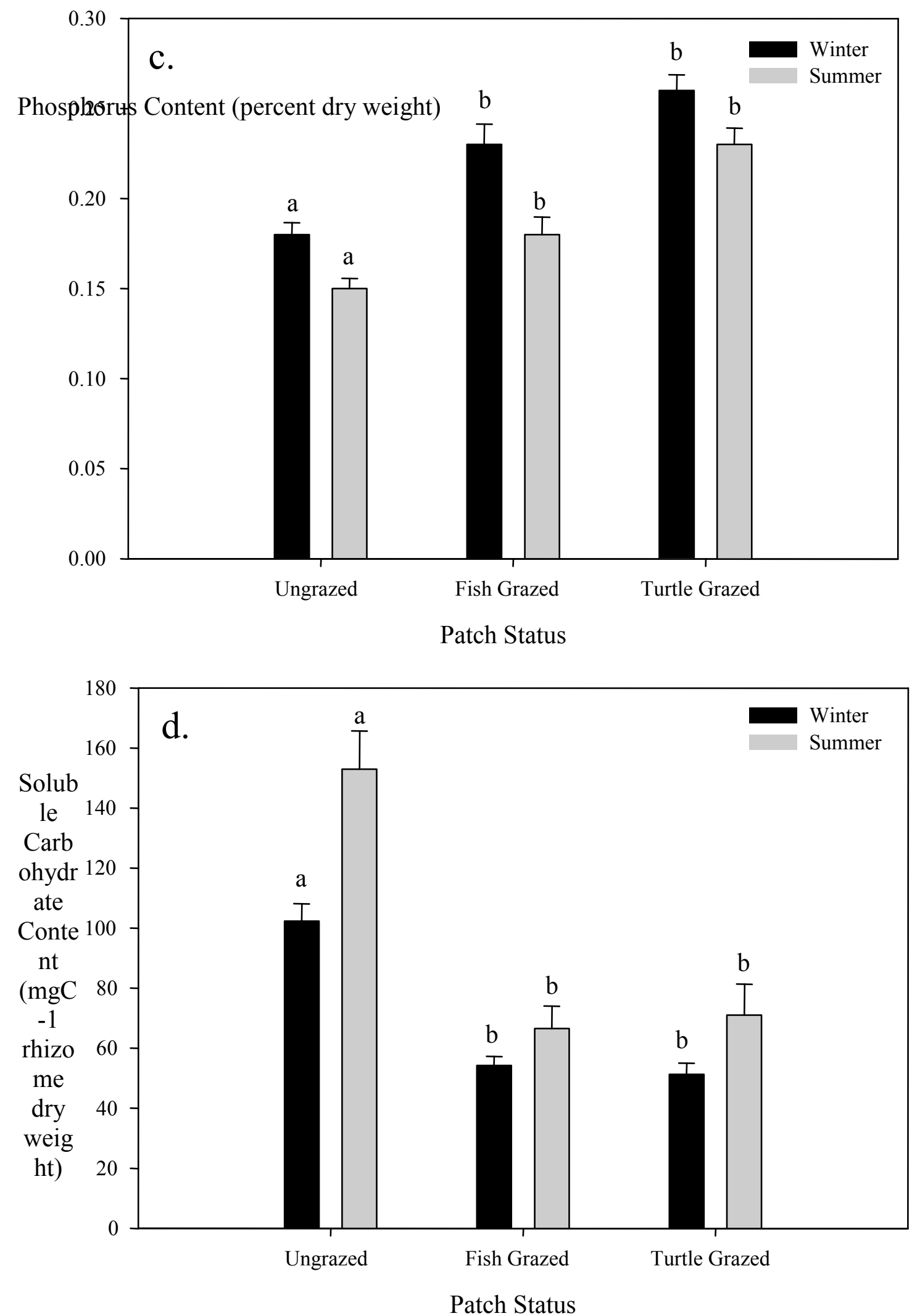

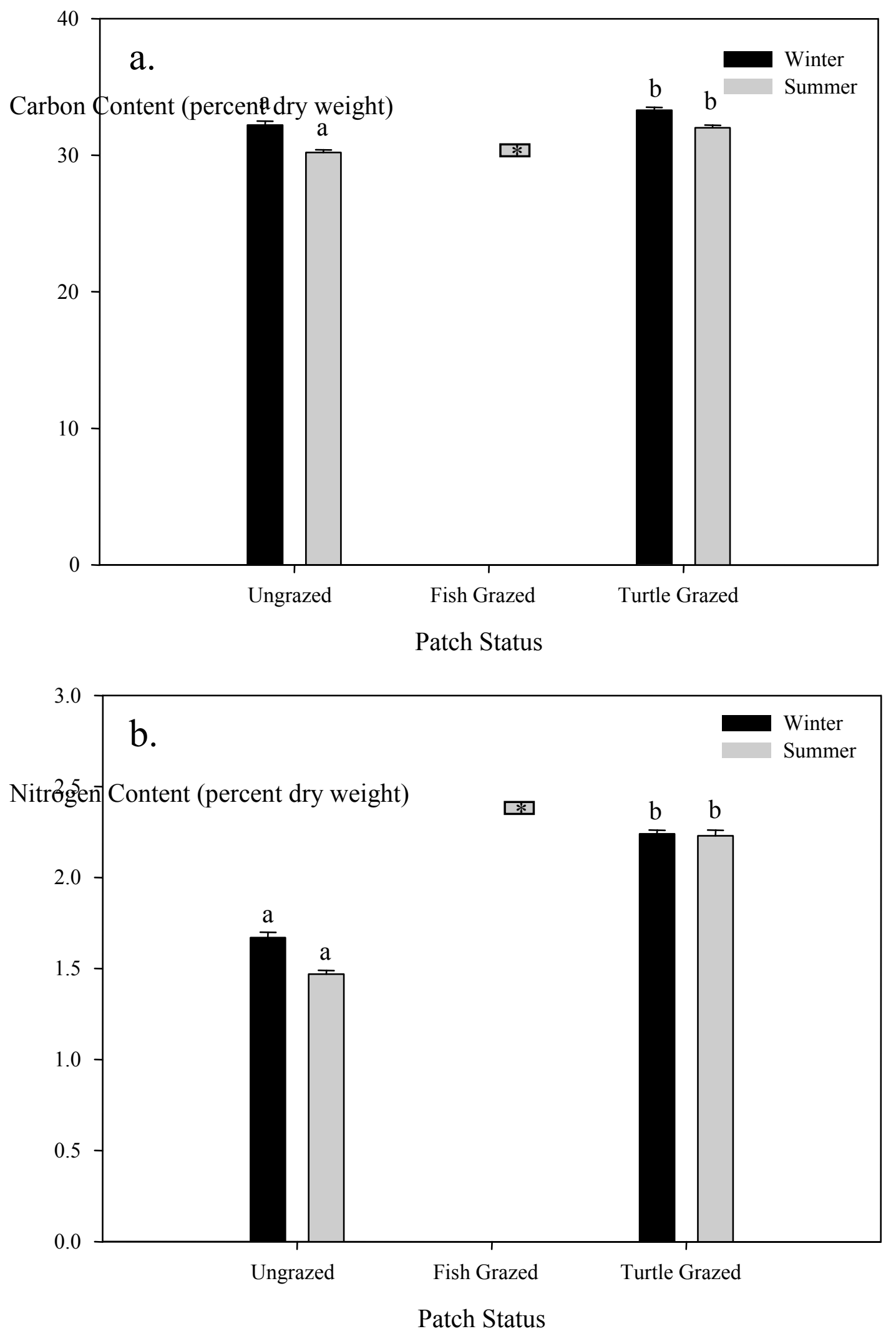


\subsection{6}

c.

Phosphorus Content (percênt dry weight)
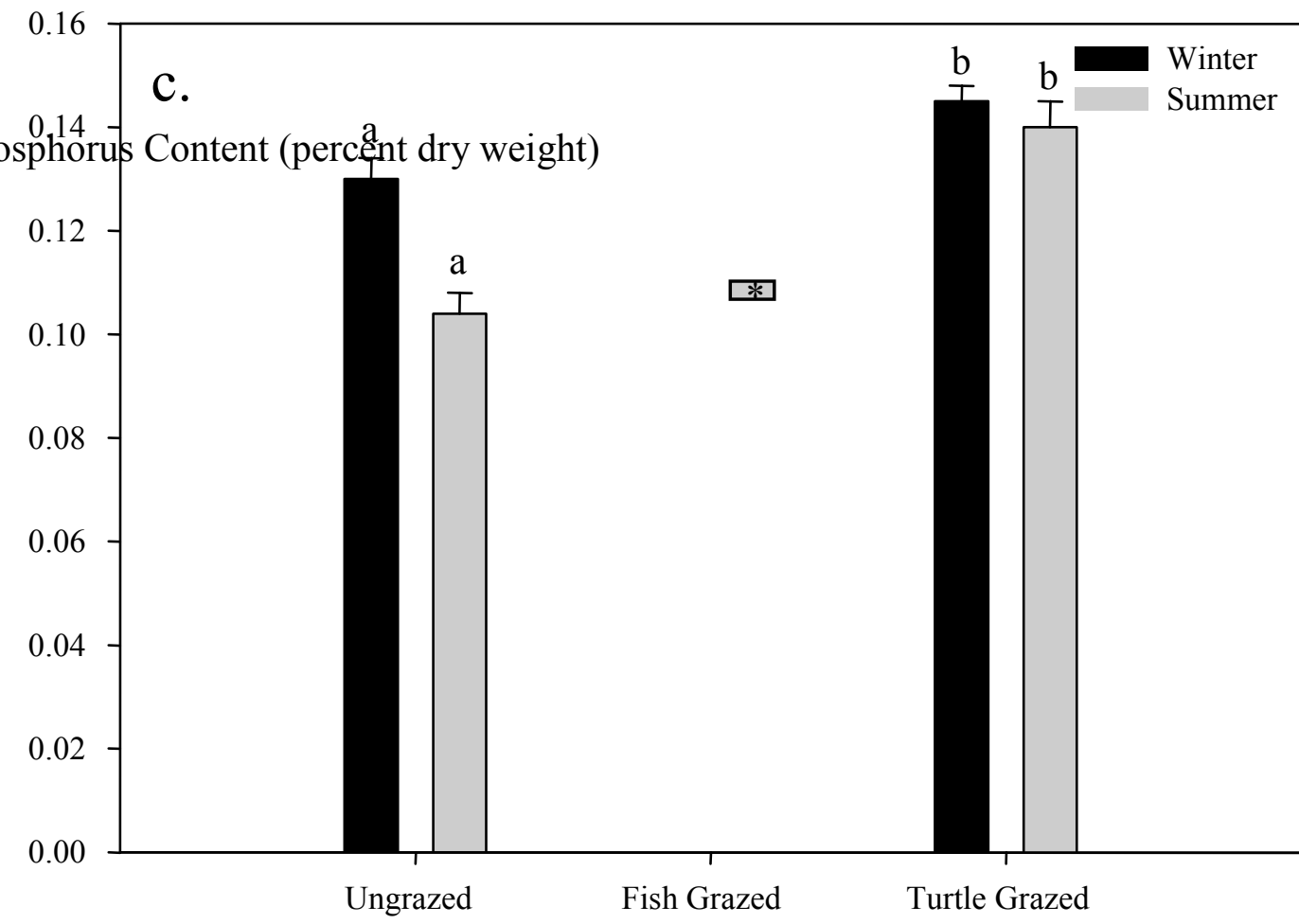

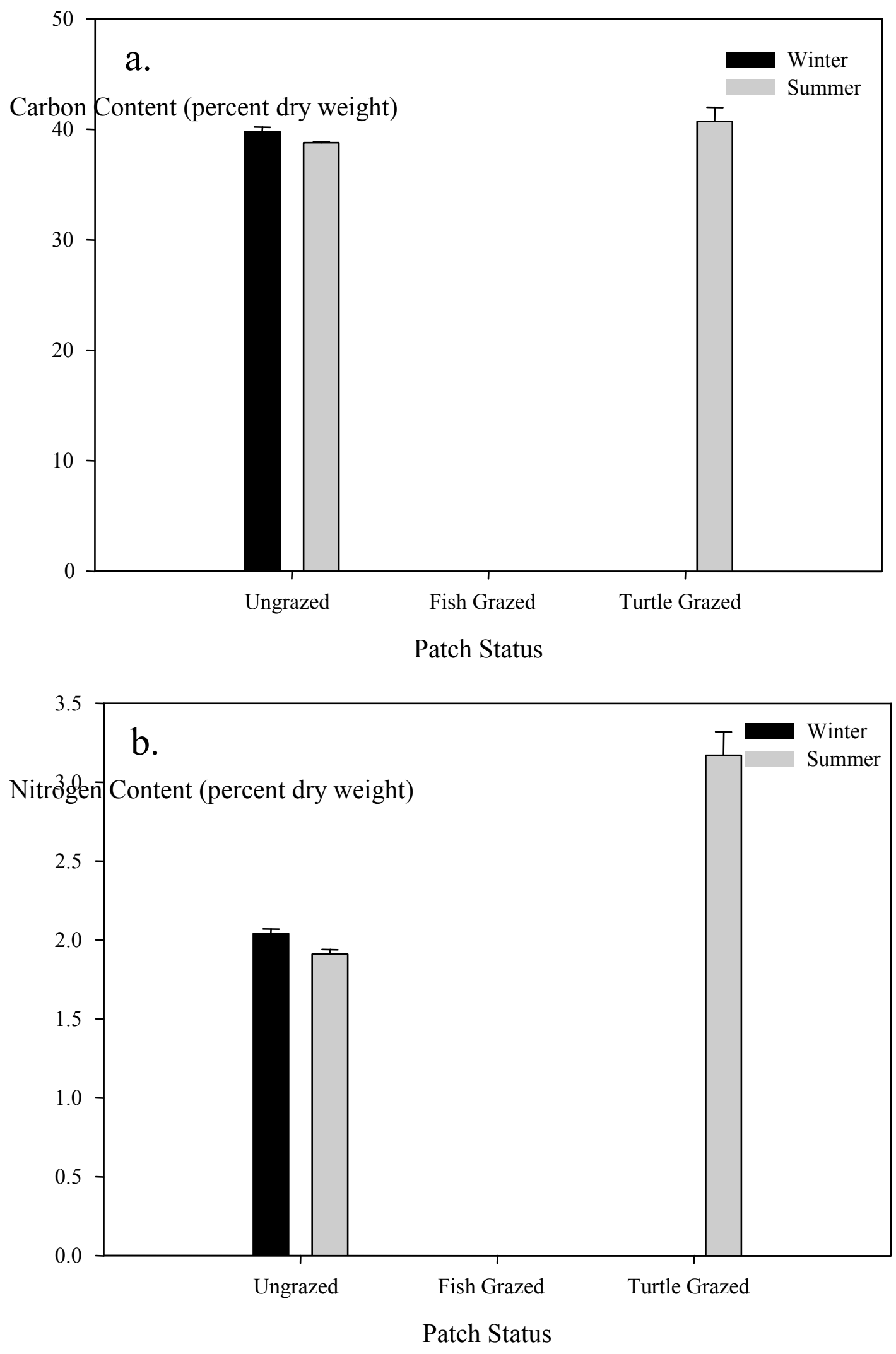


\section{c.}

Phosphorus Content (percent dry weight)

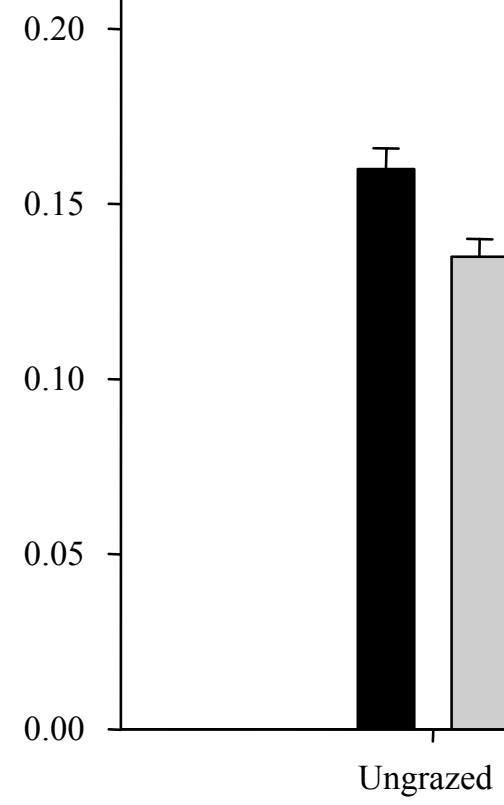

Phosphoru Content (percent dry weight)

Ungrazed
Winter

Summer

Fish Grazed

Turtle Grazed

Patch Status

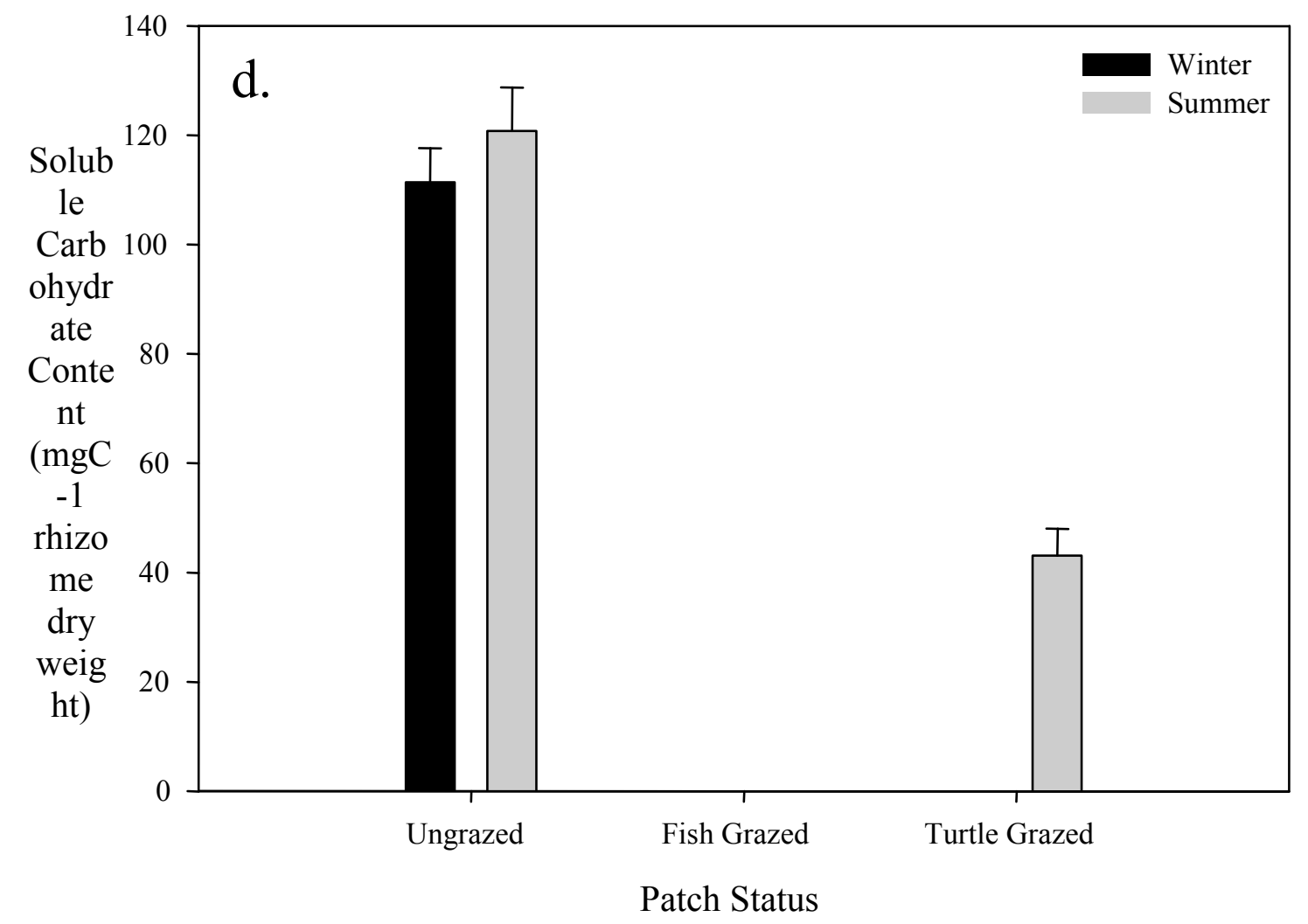




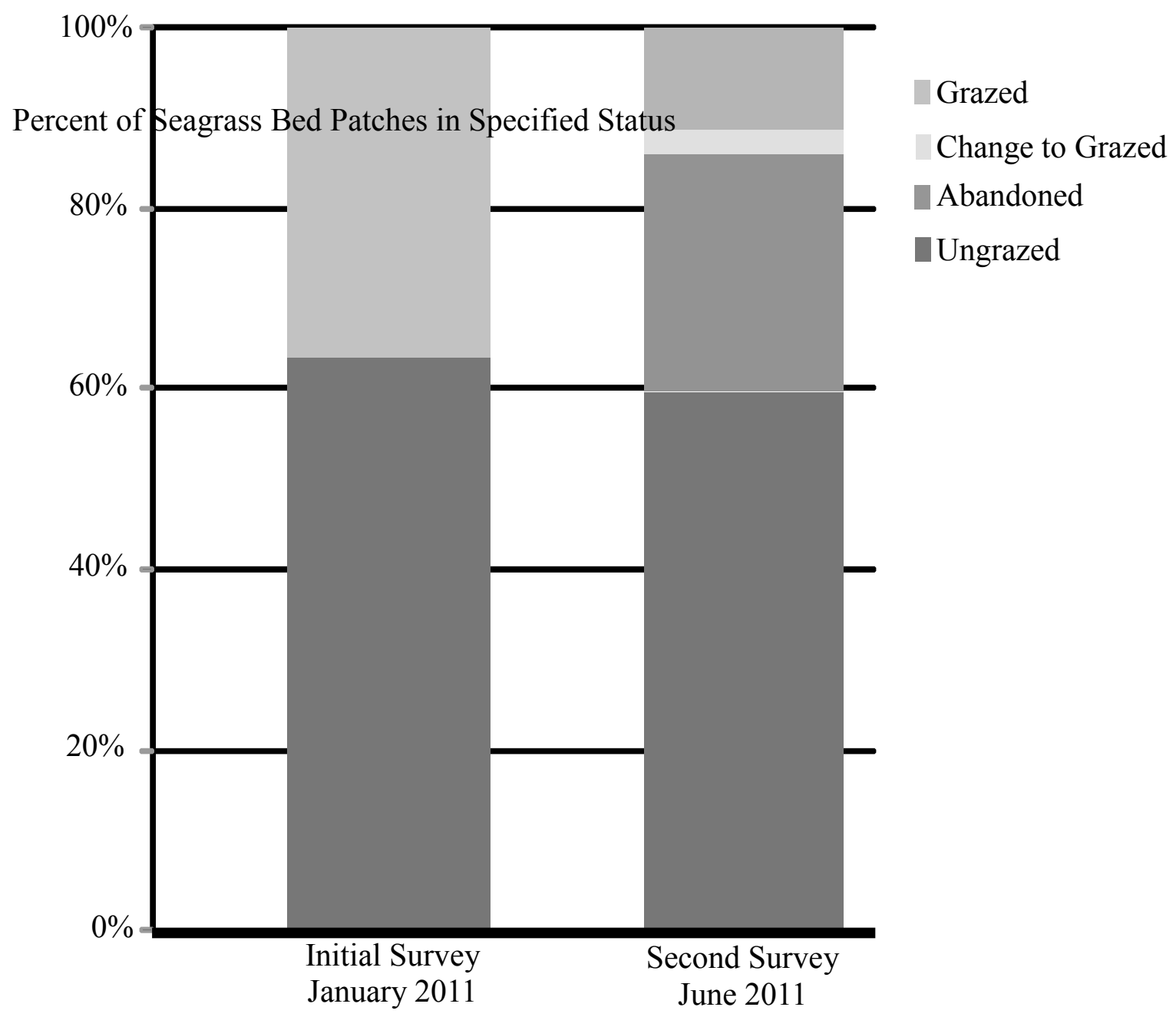



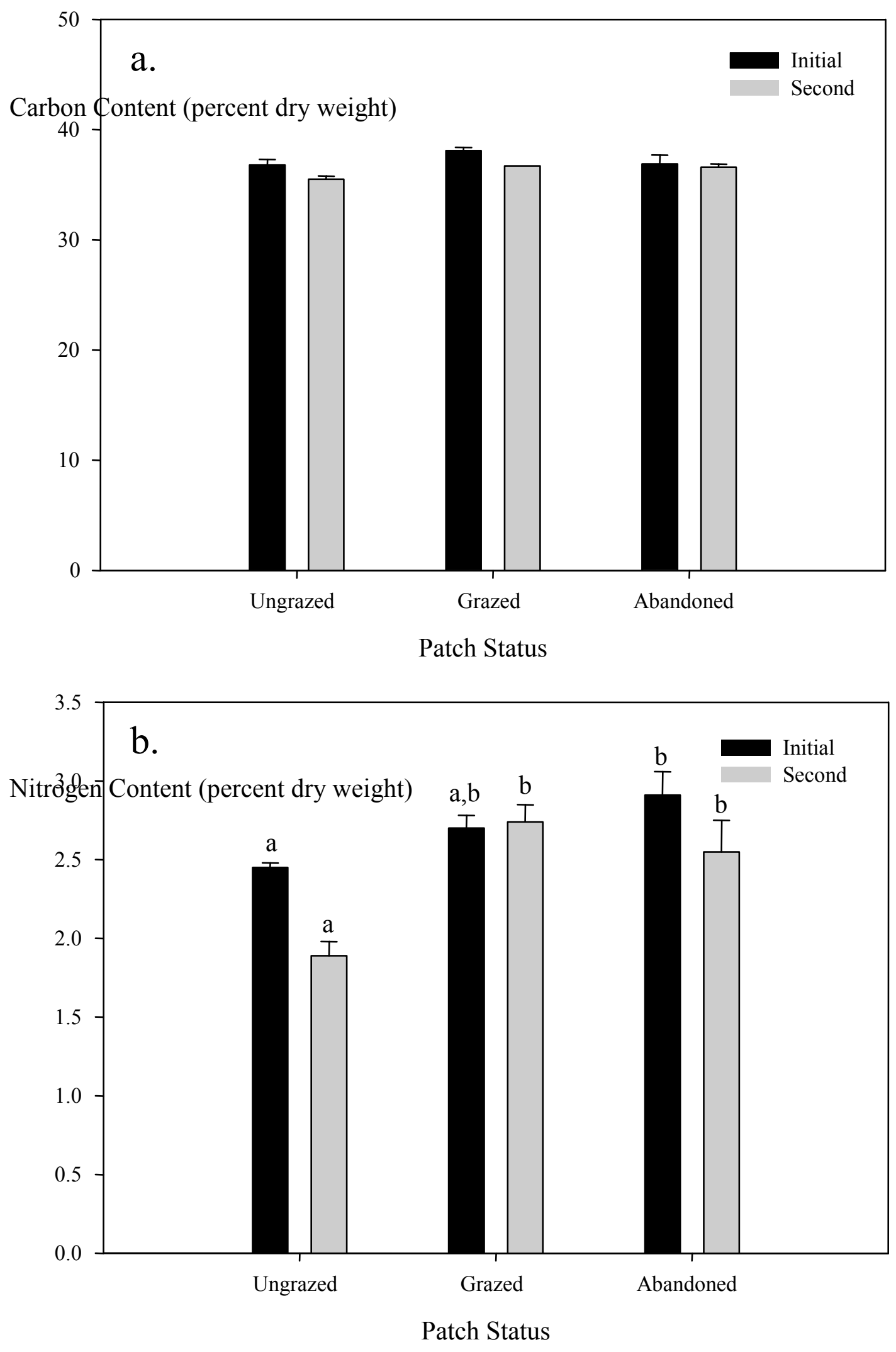

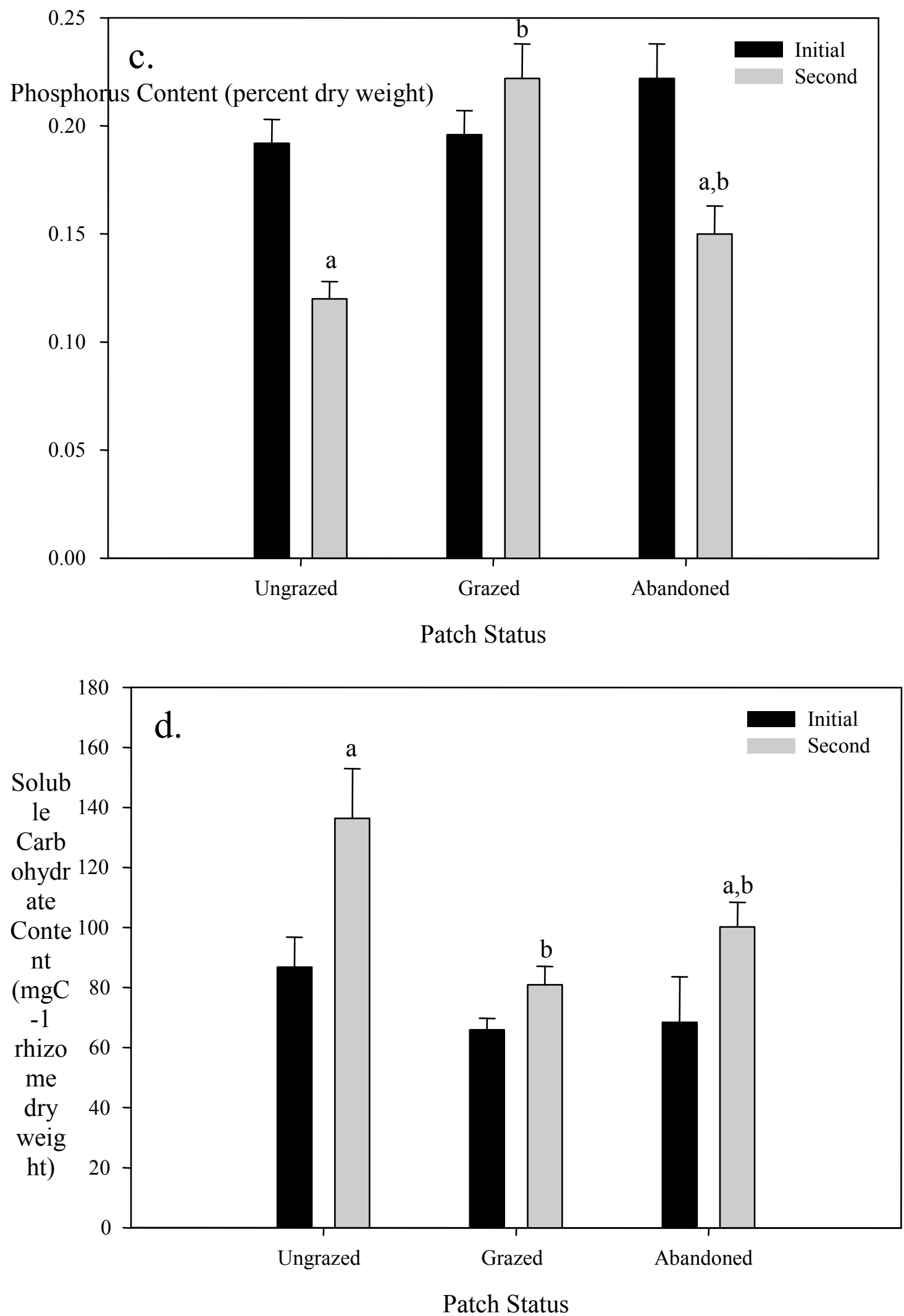

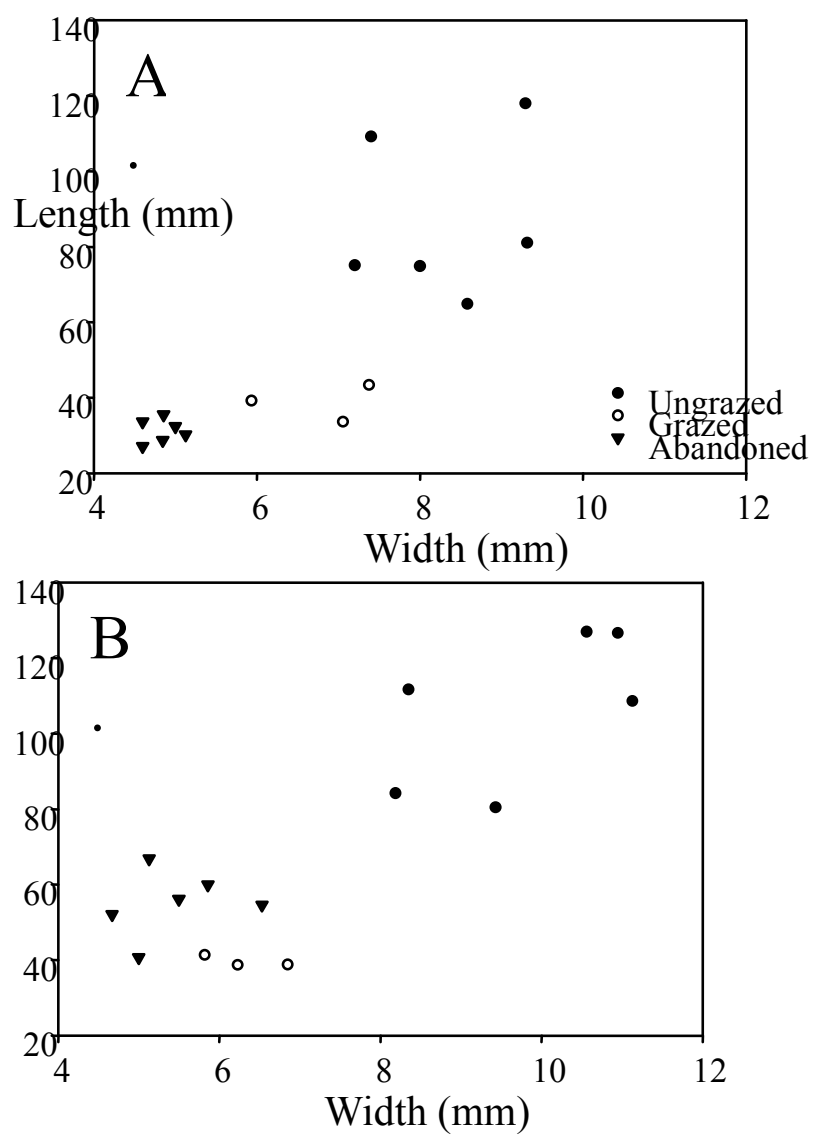


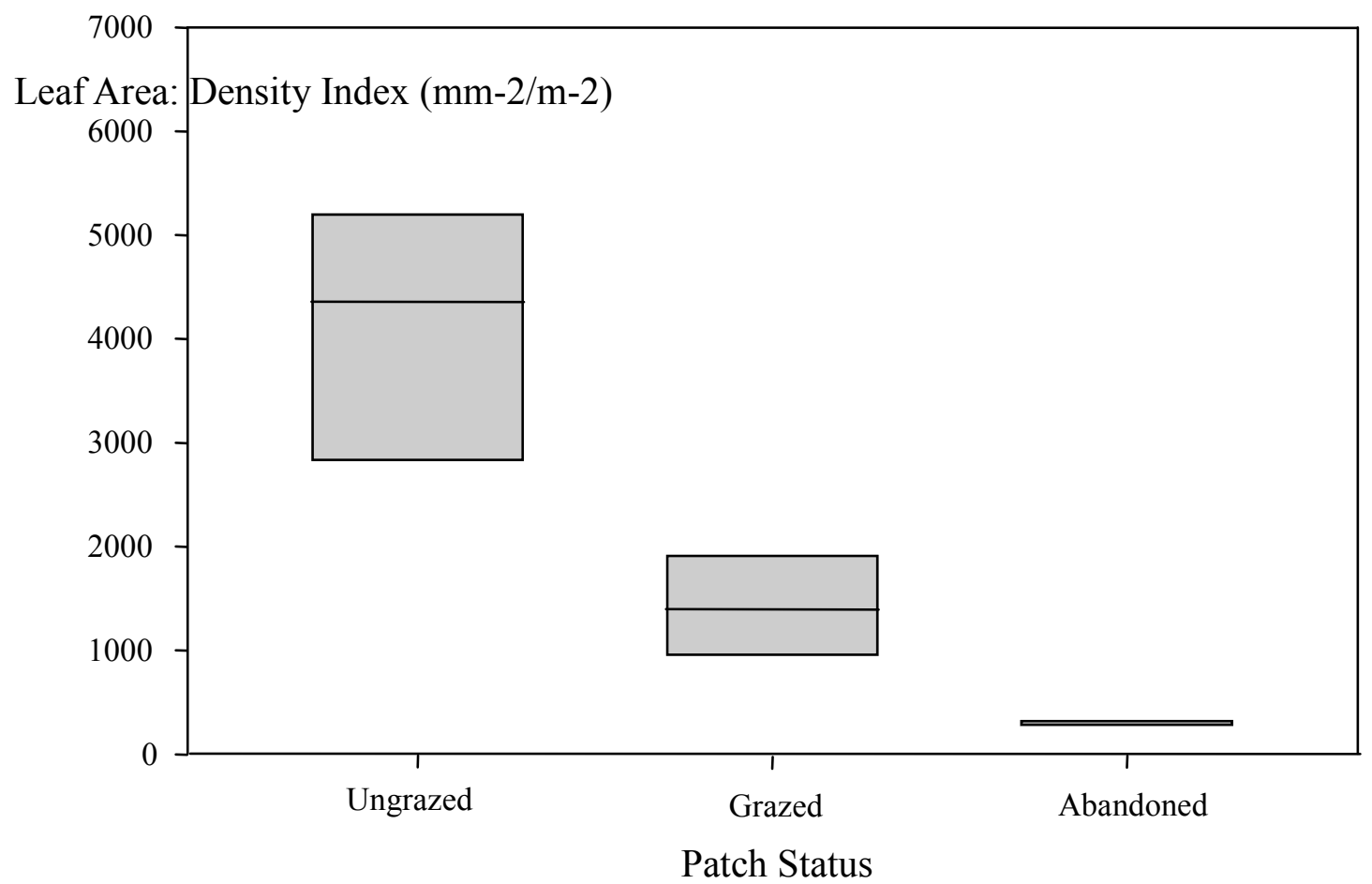


CHAPTER IV: Increased algal dominance despite presence of Diadema antillarum populations on a Caribbean coral reef

Abstract

Following the Caribbean-wide massive mortality of Diadema antillarum (Philippi, 1845), many coral ecosystems experienced a shift to a benthos dominated by algal assemblages. Populations of $D$. antillarum herbivore have been slow to recover, and further impacts on local and regional-scales have severely threatened the health of coral reefs. From 2008-2011 the population of D. antillarum and structure of the benthic community were monitored within Akumal Bay, Mexico as a heavily impacted ecosystem. Across the four years of the study, densities of adult $D$. antillarum did not significantly change and were highest on backreef sites (mean $1.30 / \mathrm{m}^{2}$ and $1.44 / \mathrm{m}^{2}$ ). Coral cover remained low at all sites (maximum 14\%) and decreased during the four years of the study. Changes in crustose coralline algae (CCA) cover varied by year but cover was significantly higher on forereef sites while cover by turf-algal-sediment (TAS) increased at all four sites. Diadema antillarum densities correlated positively with coral and CCA cover in the backreef sites where sea urchin densities were higher but no correlation occurred with TAS and turf. Where Echinometra lucunter (Linnaeus, 1758) sea urchins were more prevalent, their densities correlated negatively with coral and positively with crustose coralline algae (CCA). Although densities of adult D. antillarum were comparable to other regions of the Caribbean, increases in TAS over the four years of this study may be evidence that even an important herbivore cannot prevent continued decline of a reef in an impacted ecosystem. 
Introduction

Coral reefs in the Caribbean have experienced major disturbances over the past few decades and continue to be under a combination of stressors including bleaching, overexploitation of herbivores, coral diseases and declining water quality which has resulted in an increase in macroalgae cover (Knowlton 1992, Aronson \& Precht 2001, Hughes et al. 2003, Bellwood et al. 2004). The importance of D. antillarum in removing macroalgae cover became evident after their massive mortality in 1983, when algal biomass abruptly increased (de Ruyter van Steveninck \& Bak 1986, Carpenter 1988, Hughes 1994). As the populations of long-spined sea urchin Diadema antillarum (Philippi, 1845) recover after their 1983 Caribbean-wide massive mortality (Lessios et al. 1984b, Lessios 2005), it remains unclear if grazing by this herbivore provides a suitable driver from which to expect a decrease in macroalgal cover on impacted coral reefs. Modeled scenarios indicate that sea urchins impart significant resilience to Caribbean reefs such that continued decline is inevitable when sea urchins are scarce (Mumby et al. 2006). However, abundant literature indicate it is a combination of factors which impacts the benthic dynamics on coral reefs and the propensity for shifts between dominant states (e.g., competition for space (Sandin \& McNamara 2012), herbivore diversity (Cheal et al. 2010), biotic histories (Aronson et al. 2004), global climate change and marine diseases (Aronson \& Precht 2006).

Nearly thirty years after this mortality event, the $D$. antillarum population recovery dynamics along with concomitant changes in benthic cover have been reported for many sites within the Caribbean basin (summarized in Ruiz-Ramos et al. 2011). Adult D. antillarum densities currently being reported within the Caribbean (e.g., 
Jamaica) are still lower than previously recorded densities but are beginning to slowly increase (Carpenter 1988, 2005, Carpenter \& Edmunds 2006). The lack of a robust population recovery is attributed to three main causes. First, the loss of cover by corals has decreased habitat complexity necessary for successful recolonization and survival by the echinoids (Lee 2006). Second, D. antillarum recovery is constrained through Allee effects since reproduction of sea urchins is density-dependent and requires close proximity to conspecifics for successful external fertilization (Levitan 1991). While larvae may recruit into the system (Eckert 1998), settlement typically requires a cue from high adult densities. Lastly, recovery may also be affected through the presence of other populations of echinoids or urchin predators (Lessios 1995). Research suggests an escape size does exist where large echinoids are less susceptible to predation but there are multiple factors which can reduce the probability of successful survival to that size (Hereu et al. 2005, Clemente et al. 2007), including direct predation on sea urchin larvae and subadults. Adult urchin predators (e.g., triggerfish, Randall et al. 1964) are highly prized commercial species whose densities have declined dramatically throughout the Caribbean. In systems heavily impacted by fishing, predation on adult $D$. antillarum is lower and sea urchin densities subsequently increase (Clemente et al. 2010), which may serve to increase the potential for recovery of these echinoids.

As sea urchin populations slowly recover, it is necessary to reassess their importance and role in driving the relative dominance of macroalgal benthic cover on coral reefs. For ecological studies of macroalgal cover, various classification strategies have been developed by which to categorize groups of macroalgae based upon their form and function in reference to the experimental questions being posed (Littler \& Littler 
1980, Steneck \& Dethier 1994, Steneck 1997). Form functional groups as developed under the relative dominance model include coral, crustose coralline algae (CCA) and turf algae and are based upon the relative disturbance (e.g., herbivory) and productivity (e.g., nutrients) experienced on a reef (Littler \& Littler 1984). Crustose coralline algae are the 'cementers' of the reef and produce an encrusting, calcifying skeleton which can cue coral settlement (Morse et al. 1988). Turf algae are attached to the substratum with rhizoids and have upright microfilamentous branches less than $2 \mathrm{~cm}$ tall. Because many species of macroalgae are phenotypically plastic, the turf functional group may include species that are considered frondose macroalgae during other portions of their life cycle (Hay 1981). Turf can be further divided into turf-algal-sediment (TAS) with identification as such determined by the presence of sediments bound within the turf mat (Airoldi \& Virgilio 1998). Turf-algal-sediment communities are strong competitors for space on the reef (McCook et al. 2001), and it has been suggested that TAS may also suppress herbivory, at least for alternative herbivores such as fish (Bellwood \& Fulton 2008), because of the presence of sediment bound within the turf.

When considering these macroalgae functional groups in study sites where $D$. antillarum populations are recovering, one expects decreased cover of turf and TAS algae and increased cover by CCA and coral (Littler \& Littler 1984, Edmunds \& Carpenter 2001, Carpenter \& Edmunds 2006, Jordan-Garza et al. 2008). In these sites, coral cover is higher while TAS and turf cover has decreased. For systems with high nutrient levels and high grazing rates, a benthos dominated by CCA is to be expected, as CCA is adapted to resist grazing pressures (Steneck 1983). The echionid-benthos relationship would be reflected in a positive correlation of $D$. antillarum to coral and CCA and a 
negative relationship to TAS and turf. Studies tracking the relationship between these different benthic covers in relatively nutrient replete sites over longer time scales are lacking but can provide interesting insight into this dynamic.

The goals of this study were to determine: (1) if the population of $D$. antillarum on a reef with high nutrient availability was recovering, producing larvae and if they were susceptible to predation by any sea urchin predator (2) if significant correlations occurred between sea urchin densities and coral reef benthic communities (3) if cover by these benthic communities changed with time and (4) the role of any other fish herbivores, if any, within the study system on these same benthic covers. The question remains if the implications for the slow recovery of $D$. antillarum herbivore will have the significant results in a nutrient-replete reef, where macroalgal cover is much higher. I hypothesize that while $D$. antillarum populations may be recovering at this study site and driving shifts towards increased CCA cover, turf and TAS biomass removal by the herbivore population in a resource-rich environment will fail to control or decrease cover by these algal functional groups.

Methodology

Study site

The coast of Quintana Roo, Mexico on the Yucatan Peninsula consists of multiple bays and lagoons along the periphery of the Mesoamerican barrier reef, the second largest coral reef system in the world. The area is experiencing a dramatic increase in tourism pressure as development projects increase land use (Murray 2007). Stream flow of pollutants directly into the water is uncommon because of the highly porous, karstic geology characteristic of this region. Instead, terrestrially-derived nutrients enter the 
coastal zone via submarine groundwater discharge and influence coastal coral, seagrass and macroalgae ecosystems. The nitrogen and phosphorus concentrations and isotopic ratios of macrophytes indicate the land-based sources of nutrients (Carruthers et al. 2005, Mutchler et al. 2007) and coral diseases have become increasingly common from eutrophication of coastal waters (Harvell et al. 2007). Studies of nitrogen isotopic content of gorgonians from Akumal established significant enrichment when compared to other sites along the MesoAmerican reef (Baker et al. 2007).

Akumal Bay reef is located approximately 300 meters from shore and is characterized by a semi-enclosed lagoon sloping towards the $3-4$ meter deep backreef, a shallow northern and southern reef crest and a 3-4 meter deep forereef (Figure 1). The reef has low coral cover (13.8\%, E. Jordán-Dahlgren unpubl.) with 50\% loss of coral cover over the last twenty years (Harvell et al. 2007) and high fishing pressure (GarciaSalgado et al. 2008). For this study, Akumal's barrier reef was divided into the northern and southern portions, separated by approximately 400 meters of patchy rather than continuous reef structure, with backreef and forereef areas for a total of four sites (Figure 1). In 1998, these reefs suffered massive 'El Niño' bleaching and outbreaks of disease, after which coral cover dramatically declined (Steneck \& Lang 2003). The North Forereef (NF) is characterized by dead stands of Acropora palmata (Lamarck, 1816) and occasional live Porites asteroides (Lamarck, 1816) and Montastraea sp. colonies while the South Forereef (SF) is predominantly dead stands of $A$. palmata. Both NF and SF are exposed to more wave action than the back reef areas, as is typical of barrier reefs. The North Backreef (NB) and South Backreef (SB) sites are characterized by live Agaricia tenuifolia (Dana, 1848), Montastraea sp. and occasional P. asteroides colonies. Backreef 
sites are intermixed with octocorals, Gorgonia ventalina (Linnaeus, 1848) (NB and SB) and Plexaurella nutans (Duchassaing, 1860) (NB). Recently, the SB and SF sites have been increasingly colonized by the zooxanthid, Palythoa caribaeorum (Duchassaing and Michelottie, 1861). The NB and NF sites are adjacent to the navigation channel, where water exchange from inside the bay occurs.

\section{Sampling methodology}

At each site in July from 2008 - 2011, thirty meter long transects were sampled parallel to the reef crest $(\mathrm{n}=6-10)$ and ten $1 \mathrm{~m}^{2}$ quadrats were placed randomly along each transect to quantify percent benthic cover and adult $D$. antillarum density. Depths among all sites ranged $2-3 \mathrm{~m}$. Benthic cover was classified as: turf (mix of filamentous algae less than $2 \mathrm{~cm}$ high), turf-algal-sediment (TAS) matrix, crustose coralline algae (CCA), macroalgae, live coral, open substrate (e.g., dead coral, bare rock) and sand. As habitat structural complexity can be a driver of $D$. antillarum distribution (Lee 2006), rugosity measurements were made every $5 \mathrm{~m}$ using the Atlantic and Gulf Rapid Reef Assessment (AGGRA) line intercept transect methodology (www.aggra.org). The difference between the highest and lowest relief portions of the reef within a 1 meter sweep of the 5 meter interval were recorded, providing a spatial index of the reef and a ratio of reef surface contour distance. Within the same $1 \mathrm{~m}^{2}$ quadrat where percent cover was recorded, density of $D$. antillarum with test diameter greater than $4 \mathrm{~cm}$ was determined. These surveys were completed during the daylight relying on the assumption that daytime locations were an adequate representation of individual sea urchin foraging areas (Carpenter 1986). 
Diadema antillarum larval recruitment into the system was measured using the methods described in Miller et al. (2009), modified from (Bak 1985). A total of 25 plates were deployed, 5 per buoyed line, along the backreef (North and South), where larval retention is highest (Hernandez et al. 2008) and at a distance $0.5-2 \mathrm{~m}$ above the substrate. Following recommendations from D. antillarum recruitment studies done in Puerto Rico (Miller et al. 2009, Williams et al. 2010), settlement plates were moved to the North Backreef site during the winter after rugosity was found to be significantly higher than both forereef sites (Table 1). The plates were visually surveyed in situ for recruits monthly in April and May 2010, biweekly in June and July 2010, and biweekly in January and February 2011, seasonal periods when sea urchin settlers have been reported in other parts of the Caribbean (Miller et al. 2009, Williams et al. 2010). After each visual survey, the larval settlement plates were replaced with clean plates to avoid settlement-preventive fouling. Used larval plates were placed in plastic bags and transported to the laboratory where they were further surveyed under magnification to count any settled larvae that may have been missed during the in situ surveys.

In 2011, each of the four sites was surveyed using a modified AGGRA method (www.aggra.org) to identify and quantify all fishes present. Six $25 \mathrm{~m}$ long x $2 \mathrm{~m}$ wide belt transects were completed in each of the study sites where data on fish length, density and identity were quantified. Following the survey, fishes were placed in groups based on whether they were considered an herbivore or sea urchin predator (e.g., triggerfish, hogfish, grunts, snapper). After determining that the majority of fish surveyed could be placed in three main herbivore groups (parrotfish, damselfish and surgeonfish) and insufficient predators precluded forming a predator group, mean counts in the three 
herbivore groups were normalized to a density of $100-\mathrm{m}^{2}$ census area per size class $(0-5$ $\mathrm{cm}, 6-10 \mathrm{~cm}, 11-20 \mathrm{~cm}, 21-30 \mathrm{~cm}$ ). Mean lengths per each size class (e.g., $2.5 \mathrm{~cm}$ for size class $0-5 \mathrm{~cm}$ ) were converted to estimated biomass using length-weight relationships (Bohnsack \& Harper 1988, Paddack et al. 2006). After the first year of the study, when it was determined that there was a small, rock-boring echinoid Echinometra lucunter (Linnaeus, 1758) at the sites, density measurements of these urchins were made in the same quadrat and with the same methodology as was used for D. antillarum.

\section{Statistical analysis}

To test for significant differences in D. antillarum and E. lucunter densities and benthic covers between the four sites each year, one-way Kruskal-Wallis tests were performed in SPSS (PASW). Mann-Whitney U tests were used for post-hoc pairwise comparisons between sites with Bonferroni corrections for experiment-wide Type I error rates. To test for significant differences in D. antillarum densities and benthic covers at each site over the four years of the survey, one-way Kruskal-Wallis tests were performed in SPSS (PASW). Mann-Whitney U tests were used for post-hoc pairwise comparisons between years with Bonferroni corrections for experiment-wide Type I error rates. Spearman rho correlations were calculated to determine the relationship between the areas of high density D. antillarum (South and North Backreef) and E. lucunter (South and North Forereef) with the benthic cover categories (TAS, turf, CCA, coral). Because sea urchin populations did not significantly change at any of the sites for the four years of the study, data were not segregated by year but were pooled for a single correlation. Quadrat-level comparisons were utilized rather than transect or site averages as the $D$. antillarum exhibited aggregative behavior on the meter-scale, as found in other studies 
(Macia et al. 2007). To test for significant differences between sites for total fish density and biomass, an ANOVA was performed after examination of data determined it was homoscedastic.

Results

Diadema antillarum density

Akumal Bay reef sites were characterized by isolated, high-density aggregations of D. antillarum with maximum 16 adults per $\mathrm{m}^{2}$ in plots containing sea urchins, but $77 \%$ of surveyed quadrats had no sea urchins (Table 1). Across all sites there was no significant difference in sea urchin density through time (Table 2) while a significant difference in density occurred each year across sites (Figure 2). The significant difference occurred in North and South Forereef sites, which had lower sea urchin densities (mean: 0.24, 0.20/sea urchins $/ \mathrm{m}^{2}$, respectively) than North and South Backreef sites (mean: 1.07, 1.31/sea urchins $/ \mathrm{m}^{2}$, respectively) (Figure 2). Forereef sites had an average $85 \%$ of quadrats without $D$. antillarum and, when present, mean abundance of sea urchins was $1.52 /$ sea urchins $/ \mathrm{m}^{2}$. Backreef sites had an average $68 \%$ of quadrats without $D$. antillarum and, when present, mean abundance of sea urchins were $3.53 /$ sea urchins $/ \mathrm{m}^{2}$.

Benthic habitat and correlations with Diadema antillarum density

Across all sites the dominant benthic cover was turf-algal-sediment (TAS), which over time significantly increased while coral and turf cover significantly decreased, regardless of $D$. antillarum presence. Positive correlations of $D$. antillarum to crustose coralline algae (CCA) cover occurred in the backreef, while CCA cover increased significantly on the South Forereef, despite lower densities of D. antillarum. 
Coral cover significantly decreased over time across all sites (Table 2) and the largest decrease in cover occurred at the South Backreef and North Backreef sites, where cover decreased $8 \%$ and $13 \%$, respectively (Figure 3a). There was a significant difference in coral cover between all sites in $2008\left(\chi^{2}=5.093, p=0.024\right)$ and $2009\left(\chi^{2}=\right.$ 5.217, $\mathrm{p}=0.022$ ), when backreef sites had significantly higher cover than forereef sites. By 2011 all sites were not significantly different from each other $\left(\chi^{2}=1.026, p=0.311\right)$ and mean coral cover was $2 \%( \pm 0.3 \mathrm{SE})$. At these backreef sites where $D$. antillarum densities were highest, there were positive correlations of D. antillarum with coral and CCA cover (Table 3). Significant differences in CCA cover occurred between sites in time $\left(\chi^{2} \geq 3.760, p \leq 0.042\right)$, which was caused by the $2-6$ times more CCA cover on forereef sites compared to backreef sites in 2010 and 2011. At the forereef sites, over $20 \%$ of the benthos was covered in CCA by 2011 and South Forereef CCA cover more than doubled (11-26\%) over the period 2008 - 2011 (Table 2, Figure 3b). The CCA cover was positively correlated to $D$. antillarum densities on the backreef sites (Table 3 ). The TAS cover became the dominant benthic cover at all four sites, having increased significantly over the course of the study (Table 2). Backreef sites had significantly less TAS than forereef sites $\left(\chi^{2} \geq 14.486, p<0.001\right.$, Figure $\left.3 c\right)$ yet negative correlations between TAS and D. antillarum density were not significant (Table 3). Across all sites, there was a significant effect of time on turf cover as sites NB, SF and NF experienced a significant decrease in turf while SB did not differ significantly from initial cover (Table 2, Figure 3d). 


\section{Diadema antillarum larval recruitment}

No D. antillarum larval recruits were found on the settlement plates during summer in situ or magnified surveys in the laboratory. There were also no E. lucunter larvae found on settlement plates in situ or during magnified surveys in the laboratory. After relocation of the plates within the backreef based on more recent literature recommendations, settlement plates still did not yield recruits.

Other faunal densities and correlations

Population densities of Echinometra lucunter did not change with time $\left(\chi^{2} \geq\right.$ 3.846, p-value $\geq 0.061$ ), but each year North and South Forereef sites (7.5 sea urchins / $\left.\mathrm{m}^{2}\right)$ had significantly more $E$. lucunter than North and South Backreef sites $\left(0.4 / \mathrm{m}^{2} ; \chi^{2} \geq\right.$ 13.331, p-value $<0.001$; Figure 4). E. lucunter populations on the South and North Forereef and benthic cover categories were negatively correlated, while turf and coral exhibited positive correlations to CCA (Table 3). Diadema antillarum predators were scarce throughout the duration of the study and there were no significant variation among sites for the three fish herbivore species: damselfish, surgeonfish and parrotfish (ANOVA, $p=0.873,0.799,0.521$, respectively; Table 4 ). Throughout the entire reef, no lobsters and no more than three triggerfish were seen in the four years of the study. No triggerfish were recorded during the 2011 surveys and other potential sea urchin predators (e.g., grunts, snapper and hogfish) were absent or occurred at densities less than 1 per $100 \mathrm{~m}^{2}$ at all sites. Fish herbivores such as Acanthurus coeruleus (Bloch \& Schneider, 1801) (blue tang), Acanthurus chirurgus (Bloch, 1787) (doctorfish) and Stegastes adustus (Troschel, 1865) (dusky damselfish) were present at densities averaging 19.5 per $100 \mathrm{~m}^{2}$ across all four sites and the majority were less than $10 \mathrm{~cm}$ in 
length with mean biomass of $14.2 \mathrm{~g} / \mathrm{m}^{2}$ (Table 4). Scarus taeniopterus (Desmarest, 1831) (Princess), Sparisoma viride (Bonnaterre, 1788) (Stoplight), Scarus iserti (Bloch, 1789) (Striped) and Sparisoma rubripinne (Valenciennes, 1840) (Yellowtail) parrotfish across all four sites were present at lower densities $\left(13.9\right.$ per $\left.100 \mathrm{~m}^{2}\right)$ with $14 \%$ greater than $20 \mathrm{~cm}$ in length and a mean biomass of $9.7 \mathrm{~g} / \mathrm{m}^{2}$ (for all parrotfish).

Discussion

Population densities of D. antillarum in Akumal Bay, Mexico at the beginning of this survey were low but comparable to current densities found at other sites within the Caribbean. Expected correlations (positive relationships between D. antillarum and crustose coralline algae (CCA) and coral cover) were found at backreef sites where $D$. antillarum densities were highest although coral cover significantly decreased at all sites. Temporal trends do not indicate the system has experienced a decrease in prevalence of an algal-dominated state as turf-algal-sediment (TAS) cover significantly increased. Herbivore populations of both sea urchins and fish remain low and the prevalence of this epilithic TAS cover within the Bay may deter feeding by these herbivores and prevent adequate control of algal biomass on the reefs of Akumal Bay.

Diadema antillarum abundance

Diadema antillarum populations in Akumal Bay did not significantly increase from 2008-2011, which is consistent with results reported during surveys from other sites in previous years, Panama (Lessios 2005) and the Florida Keys (Chiappone et al. 2002). Although historic sea urchin density data is not available for Akumal Bay, the highest average densities recorded during this survey $\left(1.44 / \mathrm{m}^{2} \mathrm{NB} 2008\right)$ are within range of those currently reported for many other areas within the Caribbean region, where these 
populations have not yet recovered (summarized in Ruiz-Ramos 2011). The significantly higher populations of D. antillarum in the North Backreef may have been due to the significantly higher rugosity at this site. Previous research has shown that D. antillarum use physical structures as refuge (Ogden 1976, Levitan \& Genovese 1989). In field manipulations, alterations in structural complexity significantly decreased macroalgal cover and significantly increased D. antillarum densities (Lee 2006). Habitat-complexity therefore facilitates the removal of macroalgae and has important consequences on both the recovery of this important herbivore and the efficacy at which macroalgal cover is reduced. The lower topographic complexity at some of our sites may act as a positive feedback to the resilience of the algal dominated state at these sites.

Successful sexual reproduction is required if local populations of sea urchins are to increase in the absence of immigration. Maximum densities of adult D. antillarum (16 sea urchins $/ \mathrm{m}^{2}$ ) were more than twice mean densities reported for another MesoAmerican Reef site in Mahahual Bay (7 sea urchins / $\mathrm{m}^{2}$; Jordan-Garza et al. 2008), yet in Akumal there was an absence of D. antillarum larvae on settlement plates. Even if a proportion of larvae produced in Akumal Bay are lost due to planktonic predators or other factors, it is a reasonable expectation that some local larvae would settle on the substrate made available on the settlement plates. If adults are successfully reproducing upstream, settlers may also arrive during the 3-5 week planktonic stage (Eckert 1998). It could be that fewer reproducing adults in Akumal Bay as well as upstream locations results in inadequate larval supply from which to sustain recruitment. Sperm limitation to successful fertilization, as quantified in other studies, often leads to extremely low larval production and these Allee effects (review in (Levitan 1995) as indicated by an absence 
of settlers. The methodology and placement of larval settlement plates were ideal to detect available larvae (e.g., successes in Puerto Rico and the Florida Keys, Miller et al. 2009) but perhaps studies on a larger spatial or temporal scale may impact results. Additional studies into the demographics of sea urchins in this area may yield important information on the mechanisms preventing successful larval production and retention into the system as well as inferences towards other impacted systems within the Caribbean. In addition, the forereef sites do host a population of Echinometra lucunter sea urchins, which may aggressively attack D.antillarum as a burrow defense strategy (Grunbaum et al. 1978), increasing juvenile mortality and preventing successful $D$. antillarum larvae recruitment on the forereef. E. lucunter densities are significantly higher on the forereef as they prefer microhabitats with greater exposure to wave action and currents (McGehee 1992), thus limiting habitat overlap with $D$. antillarum as physical forcing determines where each sea urchin exists. Perhaps because of this, studies on the competitive outcomes of $D$. antillarum as an intruder as well as defender with E. lucunter are limited (Shulman 1990). Despite the perceived minimal interactions between these two echinoids, Akumal Bay E. lucunter populations on the forereef are on average higher than those found on other Caribbean reefs $\left(1.24 / \mathrm{m}^{2}\right.$, Lessios et al. 1984a), thus potentially increasing their relative importance in structuring the benthos at this study site. It may be that as populations of E. lucunter are established on the forereef, they competitively exclude other echinoids similar to original hypotheses behind interactions studied between E. viridis and D. antillarum (Williams 1981), rather than through later theorized mechanisms of settlement facilitation (McClanahan 1999, Lessios 2005). 


\section{Benthos relationships}

Although D. antillarum densities were within ranges found at other sites and suggest a positive relationship between sea urchin density and CCA/coral cover in the backreef environment, the system is still experiencing an overall increase in TAS cover. Sea urchins may be removing some turf and TAS algal cover, providing space for CCA to settle and cue coral settlement, yet sea urchins are not decreasing TAS cover. Prior to the massive mortality event, $D$. antillarum densities of $16 / \mathrm{m}^{2}$ were shown to completely clear algae from the reef while $4 / \mathrm{m}^{2}$ densities correlated to the highest coral spat densities (Sammarco 1980). More recent research suggests densities as low as $1 / \mathrm{m}^{2}$ can maintain a cropped algae patch (Dahlgren, C., personal communication in Mumby et al. 2006). My densities along the backreef were $>1 / \mathrm{m}^{2}$ yet the population of $D$. antillarum was unable to maintain a cropped algae substrate and an increase in coral cover did not occur. Decline in coral cover may be caused by a multitude of factors including stresses the coral experiences in competition with the increased epilithic TAS cover (McCook et al. 2001), reproductive restrictions within the coral population itself, historic disturbances from diseases throughout the MesoAmerican region (Aronson \& Precht 2001) and many other factors impacting coral reef health (Mumby \& Steneck 2008). Like sea urchins, corals are impacted by the Allee effect and the highest coral cover found at the end of the study $(1 \%$ at $\mathrm{NB})$ is incredibly low compared to other regions of the MesoAmerican Reef, which report an average of $22 \%$ cover by live coral (Schutte 2010). Small scale disturbances from the low level of herbivory or from wave action may be providing substrate for coral larvae settlement but coral populations within Akumal may have decreased to the extent that they are unable to successfully produce enough planulae to 
counter their mortality. There are a multitude of unknown factors in addition to herbivory which should be considered when addressing causes of coral reef decline. While there is some research to suggest a more direct correlation between sea urchins and coral growth (Myhre \& Acevedo-Gutierrez 2007, Idjadi et al. 2010), in Akumal this relationship does not seem to be as direct.

Considering those characteristics of macroalgal functional groups, potentially higher rates of herbivory from sea urchin populations should be reflected in a benthos dominated by CCA. In areas with fewer sea urchins and less herbivory, macroalgae should dominate the benthos. A positive correlation between D. antillarum and coral and CCA did occur on the backreef, where these sea urchin populations were highest, yet CCA was not the dominant cover at these sites. In fact, overall cover by CCA on the total reef area surveyed during all four years of the study was low $(<17 \%)$. Despite low densities of $D$. antillarum on the forereef, CCA cover was higher than backreef sites, contrary to my hypothesized outcomes. This may be a response to E. lucunter populations present there or may be representative of recently explored negative effects of D. antillarum on CCA (O'Leary \& McClanahan 2010). In addition to herbivory as a source of disturbance, forereefs are typically highly influenced by wave action (Roberts 1983), which can influence epilithic cover. Cover by CCA is highly resistant to mechanical stress and research on TAS mats suggest they may be characteristic of highenergy environments (Bellwood \& Fulton 2008), despite decreased sedimentation rates in these areas (Airoldi \& Virgilio 1998). This consideration of wave action as a disturbance in addition to herbivory is not often considered when predicting dominate benthic cover on coral reefs. 
The population of Echinometra lucunter sea urchins may add to the overall level of herbivory at the forereef sites, increasing the amount of substrate available for CCA colonization and growth. For E. lucunter, intra- and interspecific aggression increases the dispersion of this species relative to resources (Shulman 1990). This dispersion can control the spatial distribution of not only the echinoids, but also of the benthic cover resistant to their herbivory, perhaps as is evident by the significant increase in CCA cover on the south forereef. As E. lucunter dominate the forereef environment, their presence had a positive correlation with CCA cover similar to D. antillarum correlations with CCA cover in the backreef. Of note is the significant negative correlation of E. lucunter densities with coral cover on the forereef, the mechanisms behind which are unknown. E. lucunter, similar to D. antillarum, did not have a significant correlation to TAS cover and therefore cannot be categorized as an adequate controller of this algal cover. With further study, this relationship may prove to play an interesting new ecological role in these echinoid/benthos dynamics.

Akumal Bay herbivorous fish populations were not significantly different at the four sites and therefore cannot explain differences in benthic cover. Their low biomass (22-72\% less than other Caribbean reefs (Paddack et al. 2009), may explain the increase in algal cover, particularly as the high-sediment content in TAS mats has been shown to suppress herbivory by fish (Bellwood \& Fulton 2008). Caribbean-wide reef fish population densities are decreasing (Paddack et al. 2009) and modeled scenarios on the resilience of Caribbean coral reefs indicate that while herbivorous fish may be able to compensate for the loss of urchins, reefs with low coral cover have less resistance to grazer loss and reef decline may be inevitable (Mumby et al. 2006). Low herbivore 
biomass may be caused by a dominance of smaller-sized fishes within the herbivore guild and results in decreased algal consumption (Paddack et al. 2006). With $86 \%$ of parrotfish less than $20 \mathrm{~cm}$ in length, the decreased herbivore biomass may decrease the ability of this guild of herbivores to control macroalgal cover. These factors, in addition to variable densities of $D$. antillarum, have an important role in the interpretation of changes to benthic cover on Akumal reefs.

In summary, Akumal reefs experienced a decline in coral cover and an increase in TAS cover despite $D$. antillarum densities comparable to other sites reported within the Caribbean. While coral and CCA covers were highest where densities of D. antillarum were highest along the backreef, this relationship did not hold universally across Akumal Bay. This suggests that grazing by $D$. antillarum has not decreased the dominance of an algal-dominated state and supports those modeled scenarios which indicate a disproportionate decrease in resilience as coral reefs with low coral cover continue to decline (Mumby et al. 2006). A snapshot in 2008 rather than over the four years of this survey may have resulted in a far different conclusion regarding the fate of this reef, which illustrates the importance of tracking temporal trends during studies involving herbivores (both sea urchin and fish) in coral-algal dynamics. In Akumal Bay, declines in coral cover may be evidence that the presence of $D$. antillarum cannot prevent the decline of the reef as it has been impacted by high TAS cover and a paucity of suitable herbivores. 
Table 1: Maximum density of Diadema antillarum per $\mathrm{m}^{2}$, frequency of plots without Diadema antillarum and rugosity index by site. ANOVA results for comparisons between all sites each year are given as chi-square value (p-value) with similar sites separated by '-'.

\begin{tabular}{|c|c|c|c|c|c|}
\hline & & 2008 & 2009 & 2010 & 2011 \\
\hline \multirow{3}{*}{$\begin{array}{c}\text { South } \\
\text { Forereef } \\
\text { (SF) }\end{array}$} & Max Density (per $\mathbf{m}^{2}$ ) & 4 & 4 & 1 & 1 \\
\hline & $\begin{array}{l}\text { Frequency of plots } \\
\text { without } D \text {. antillarum }\end{array}$ & $74 \%$ & $84 \%$ & $98 \%$ & $92 \%$ \\
\hline & Rugosity & \multicolumn{2}{|c|}{ Index: 60} & \multicolumn{2}{|c|}{ SE: 4} \\
\hline \multirow{3}{*}{$\begin{array}{c}\text { North } \\
\text { Forereef } \\
\text { (NF) }\end{array}$} & Max Density (per $\left.\mathrm{m}^{2}\right)$ & 3 & 5 & 0 & 1 \\
\hline & $\begin{array}{l}\text { Frequency of plots } \\
\text { without } D \text {. antillarum }\end{array}$ & $72 \%$ & $66 \%$ & $100 \%$ & $95 \%$ \\
\hline & Rugosity & \multicolumn{2}{|c|}{ Index: 61} & \multicolumn{2}{|c|}{ SE: 4} \\
\hline \multirow{3}{*}{$\begin{array}{c}\text { South } \\
\text { Backreef } \\
\text { (SB) }\end{array}$} & Max Density (per $\mathbf{m}^{2}$ ) & 7 & 8 & 8 & 9 \\
\hline & $\begin{array}{l}\text { Frequency of plots } \\
\text { without } D \text {. antillarum }\end{array}$ & $87 \%$ & $63 \%$ & $58 \%$ & $73 \%$ \\
\hline & Rugosity & \multicolumn{2}{|c|}{ Index: 82} & \multicolumn{2}{|c|}{ SE: 5} \\
\hline \multirow{3}{*}{$\begin{array}{c}\text { North } \\
\text { Backreef } \\
\text { (NB) }\end{array}$} & Max Density (per $\mathbf{m}^{2}$ ) & 16 & 11 & 12 & 8 \\
\hline & $\begin{array}{l}\text { Frequency of plots } \\
\text { without } D \text {. antillarum }\end{array}$ & $67 \%$ & $68 \%$ & $64 \%$ & $67 \%$ \\
\hline & Rugosity & \multicolumn{2}{|c|}{ Index: 111} & \multicolumn{2}{|c|}{ SE: 11} \\
\hline
\end{tabular}


Table 2: Kruskal-Wallis Chi-square $\left(\chi^{2}\right)$ and p-values across all years for each site (df 3; independent variable: year). Years not significantly different are presented with a '-" between years $(2008=1,2009=2,2010=3 ; 2011=4)$.

\begin{tabular}{|c|c|c|c|c|c|c|c|c|c|c|}
\hline \multirow{2}{*}{ Site } & \multicolumn{2}{|c|}{ Diadema antillarum } & \multicolumn{2}{|c|}{ Coral } & \multicolumn{2}{|c|}{$\begin{array}{l}\text { Crustose Coralline } \\
\text { Algae (CCA) }\end{array}$} & \multicolumn{2}{|c|}{$\begin{array}{c}\text { Turf Algal } \\
\text { Sediment (TAS) }\end{array}$} & \multicolumn{2}{|c|}{ Turf } \\
\hline & $\chi^{2}$ & p-value & $\chi^{2}$ & p-value & $\chi^{2}$ & $\mathrm{p}$-value & $\chi^{2}$ & $\mathrm{p}$-value & $\chi^{2}$ & $\mathrm{p}$-value \\
\hline \multirow{2}{*}{$\begin{array}{l}\text { South } \\
\text { Forereef }\end{array}$} & 22.308 & $<0.001$ & 80.22 & $<0.001$ & 46.78 & $<0.001$ & 121.09 & $<0.001$ & 276.22 & $<0.001$ \\
\hline & \multicolumn{2}{|c|}{$1-2-3-4$} & \multicolumn{2}{|c|}{$2-3-4$} & \multicolumn{2}{|c|}{$\begin{array}{lll}1-2 & 2-3 & 3-4\end{array}$} & \multicolumn{2}{|c|}{$2-3-4$} & \multicolumn{2}{|c|}{$2-3-4$} \\
\hline \multirow{2}{*}{$\begin{array}{l}\text { North } \\
\text { Forereef }\end{array}$} & 34.971 & $<0.001$ & 28.05 & 0.011 & 11.18 & 0.011 & 148.43 & $<0.001$ & 193.68 & $<0.001$ \\
\hline & \multicolumn{2}{|c|}{$1-2-4 \quad 2-3$} & \multicolumn{2}{|c|}{$2-3-4$} & \multicolumn{2}{|c|}{$1-2 \quad 1-3-4$} & \multicolumn{2}{|c|}{$1-2 \quad 3-4$} & \multicolumn{2}{|c|}{$3-4$} \\
\hline \multirow{2}{*}{$\begin{array}{c}\text { South } \\
\text { Backreef }\end{array}$} & 20.364 & $<0.001$ & 60.62 & $<0.001$ & 33.99 & $<0.001$ & 54.09 & $<0.001$ & 10.51 & 0.015 \\
\hline & \multicolumn{2}{|c|}{$1-42-3-4$} & \multicolumn{2}{|c|}{$1-2-3$} & \multicolumn{2}{|c|}{$\begin{array}{llll}-2 & 2-3 & 3-4\end{array}$} & \multicolumn{2}{|c|}{$1-2-3$} & \multicolumn{2}{|c|}{$1-3 \quad 3-4$} \\
\hline \multirow{2}{*}{$\begin{array}{c}\text { North } \\
\text { Backreef }\end{array}$} & 21.66 & $<0.001$ & 21.66 & 0.186 & 4.81 & 0.186 & 8.45 & 0.038 & 42.06 & $<0.001$ \\
\hline & \multicolumn{2}{|c|}{$1-2-3-4$} & \multicolumn{2}{|c|}{$2-3$} & \multicolumn{2}{|c|}{$1-2 \quad 2-3-4$} & \multicolumn{2}{|c|}{$1-2-3 \quad 3-4$} & \multicolumn{2}{|c|}{$\begin{array}{lll}1-2 & 2-3 & 3-4\end{array}$} \\
\hline
\end{tabular}


Table 3: Spearman rho correlations between Diadema antillarum density on the North and South Backreef with the benthic cover categories and Echinometra lucunter on the North and South Forereef with the benthic cover categories ( $n s=$ no significant correlation).

\begin{tabular}{|c|c|c|c|c|c|}
\hline & & $\begin{array}{c}\text { Turf-Algal- } \\
\text { Sediment } \\
\text { (TAS) }\end{array}$ & Turf & $\begin{array}{c}\text { Crustose } \\
\text { Coralline Algae } \\
\text { (CCA) } \\
\end{array}$ & Coral \\
\hline \multirow{2}{*}{$\begin{array}{c}\text { Diadema } \\
\text { antillarum }\end{array}$} & Spearman Rho & \multirow{2}{*}{$n s$} & \multirow{2}{*}{$n s$} & 0.484 & 0.322 \\
\hline & p-value & & & $<0.001$ & $<0.001$ \\
\hline \multirow{2}{*}{$\begin{array}{l}\text { Echinometra } \\
\text { lucunter }\end{array}$} & Spearman Rho & \multirow{2}{*}{$n s$} & -0.200 & 0.247 & -0.116 \\
\hline & p-value & & $<0.001$ & $<0.001$ & 0.011 \\
\hline
\end{tabular}


Table 4: Herbivorous fish densities (per $100 \mathrm{~m}^{2} \pm$ standard error) and biomass $\left(\mathrm{g} / \mathrm{m}^{2}\right)$ at all four sites in 2011.

\begin{tabular}{|c|c|c|c|c|c|c|c|}
\hline & & $0-5 \mathrm{~cm}$ & $6-10 \mathrm{~cm}$ & $11-20 \mathrm{~cm}$ & $21-30 \mathrm{~cm}$ & $\begin{array}{c}\text { Total } \\
\text { Density }\end{array}$ & $\begin{array}{c}\text { Total } \\
\text { Biomass }\end{array}$ \\
\hline \multirow[t]{4}{*}{ Damselfish } & South Forereef & $3.0 \pm 0.5$ & $5.4 \pm 0.6$ & $7.4 \pm 0.4$ & $0.0 \pm 0.0$ & 15.8 & 11.8 \\
\hline & North Forereef & $0.4 \pm 0.2$ & $5.0 \pm 0.5$ & $9.4 \pm 0.8$ & $0.0 \pm 0.0$ & 14.8 & 13.6 \\
\hline & South Backreef & $3.0 \pm 0.5$ & $4.0 \pm 0.5$ & $9.4 \pm 0.4$ & $0.0 \pm 0.0$ & 16.4 & 13.5 \\
\hline & North Backreef & $0.4 \pm 0.2$ & $5.0 \pm 0.5$ & $8.6 \pm 0.7$ & $0.0 \pm 0.0$ & 14.0 & 12.9 \\
\hline \multirow[t]{4}{*}{ Surgeonfish } & South Forereef & $3.0 \pm 0.3$ & $10.0 \pm 0.7$ & $10.6 \pm 1.1$ & $0.0 \pm 0.0$ & 23.6 & 15.7 \\
\hline & North Forereef & $3.0 \pm 0.3$ & $12.4 \pm 0.9$ & $9.4 \pm 0.6$ & $0.0 \pm 0.0$ & 24.8 & 14.9 \\
\hline & South Backreef & $3.0 \pm 0.3$ & $9.0 \pm 0.7$ & $10.0 \pm 0.8$ & $0.0 \pm 0.0$ & 22.0 & 14.9 \\
\hline & North Backreef & $3.0 \pm 0.3$ & $10.4 \pm 0.5$ & $11.4 \pm 0.8$ & $0.0 \pm 0.0$ & 24.8 & 16.5 \\
\hline \multirow[t]{4}{*}{ Parrotfish } & South Forereef & $0.0 \pm 0.0$ & $6.4 \pm 1.1$ & $4.6 \pm 0.6$ & $1.6 \pm 0.4$ & 12.6 & 8.1 \\
\hline & North Forereef & $0.0 \pm 0.0$ & $5.0 \pm 1.2$ & $7.6 \pm 0.6$ & $3.0 \pm 0.6$ & 15.6 & 10.5 \\
\hline & South Backreef & $0.0 \pm 0.0$ & $4.4 \pm 1.0$ & $6.0 \pm 0.6$ & $2.4 \pm 0.4$ & 12.8 & 9.1 \\
\hline & North Backreef & $0.0 \pm 0.0$ & $4.6 \pm 0.8$ & $8.2 \pm 0.7$ & $1.6 \pm 0.4$ & 14.4 & 10.9 \\
\hline
\end{tabular}


Figure 1: Map of Akumal Bay, Quintana Roo, Mexico (Latitude: 20²3’45” N

Longitude: $\left.87^{\circ} 18^{\prime} 52^{\prime \prime} \mathrm{W}\right)$. Study sites indicated by boxes $(\mathrm{SF}=$ south forereef, $\mathrm{NF}=$ north forereef, $\mathrm{SB}=$ south backreef, $\mathrm{NB}=$ north backreef).

Figure 2: Density of adult Diadema antillarum (letters indicate significant differences in the same year between sites). Solid circle $=$ south forereef, Open circle $=$ north forereef, solid triangle $=$ south backreef, open triangle $=$ north backreef.

Figures 3A-D: Percent benthic cover for each of the four sites over four years (letters indicate significant differences in the same year between sites). Note the difference in scale between 3A-B and 3C-D. Solid circle $=$ south forereef, Open circle $=$ north forereef, solid triangle $=$ south backreef, open triangle $=$ north backreef.

Figure 4: Density of Echinometra lucunter (letters indicate significant difference in the same year between sites). Solid circle $=$ south forereef, Open circle $=$ north forereef, solid triangle $=$ south backreef, open triangle $=$ north backreef. 


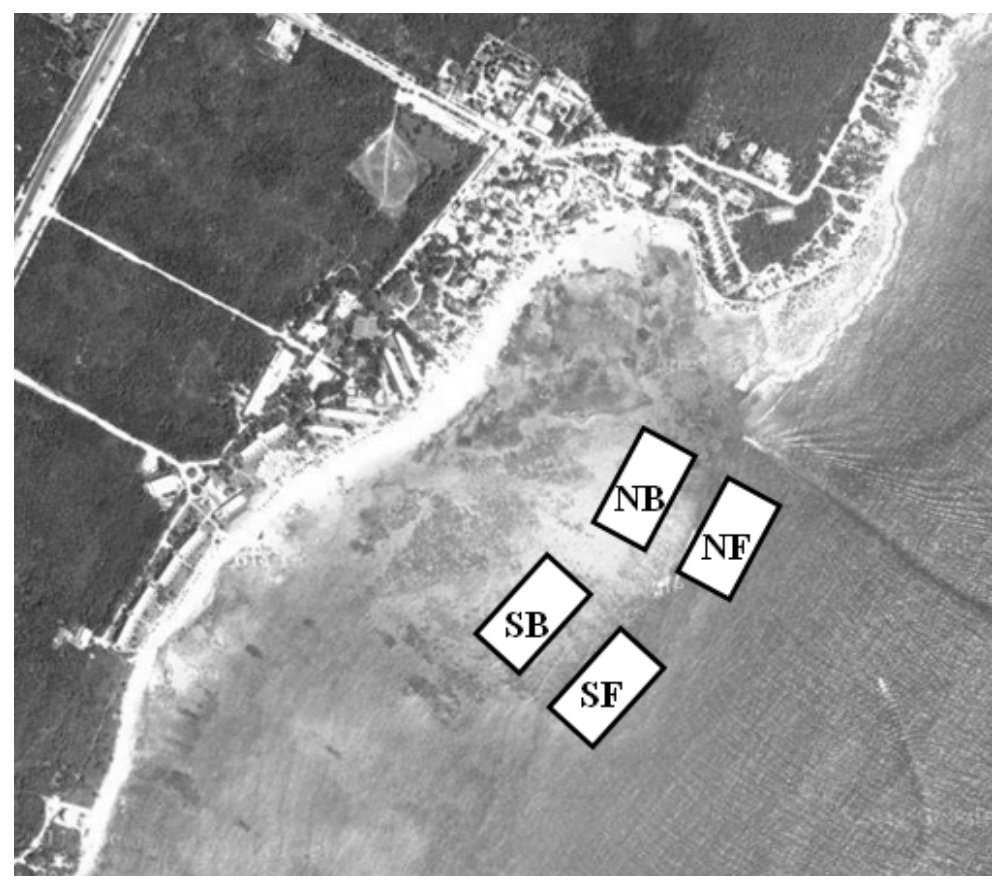




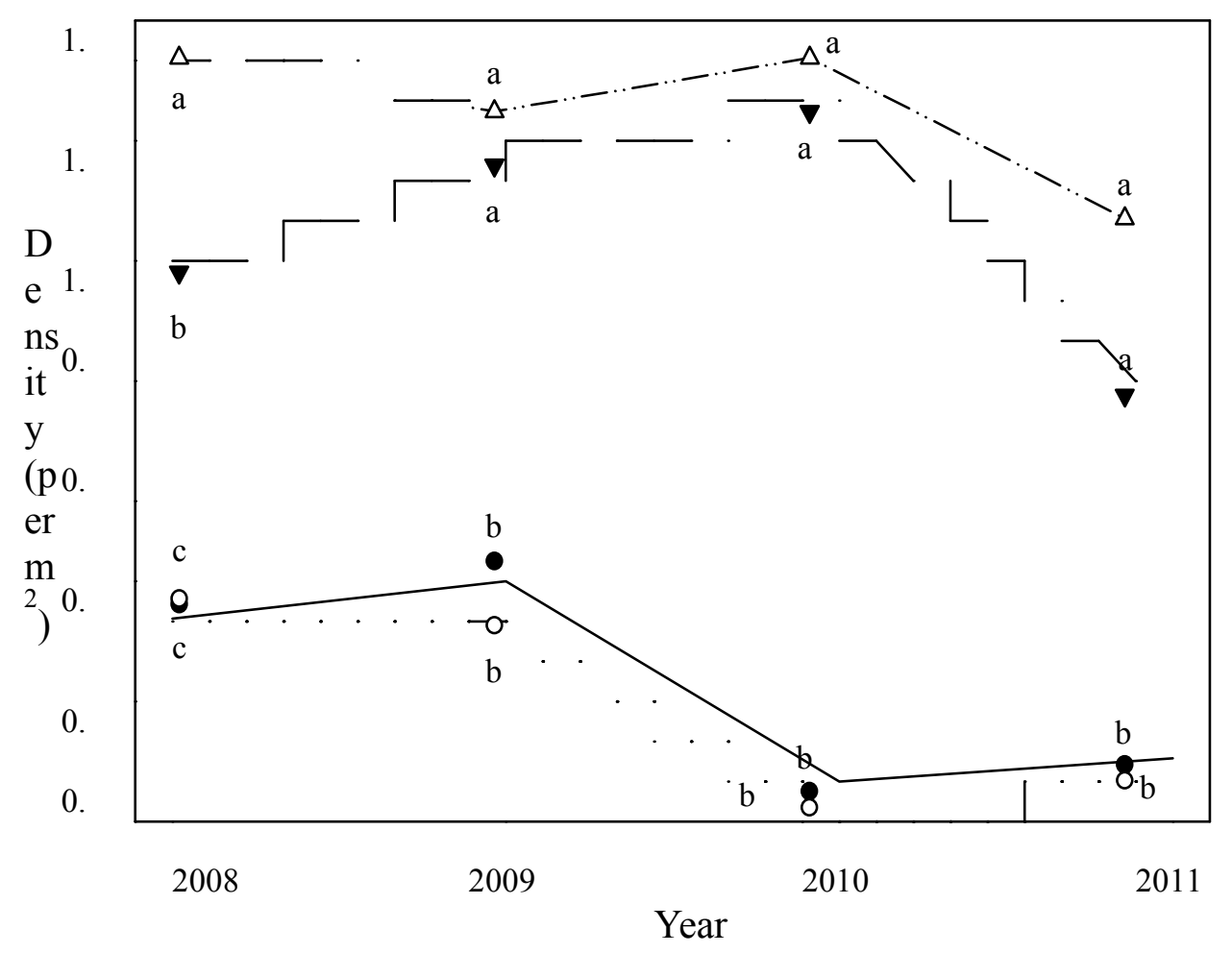



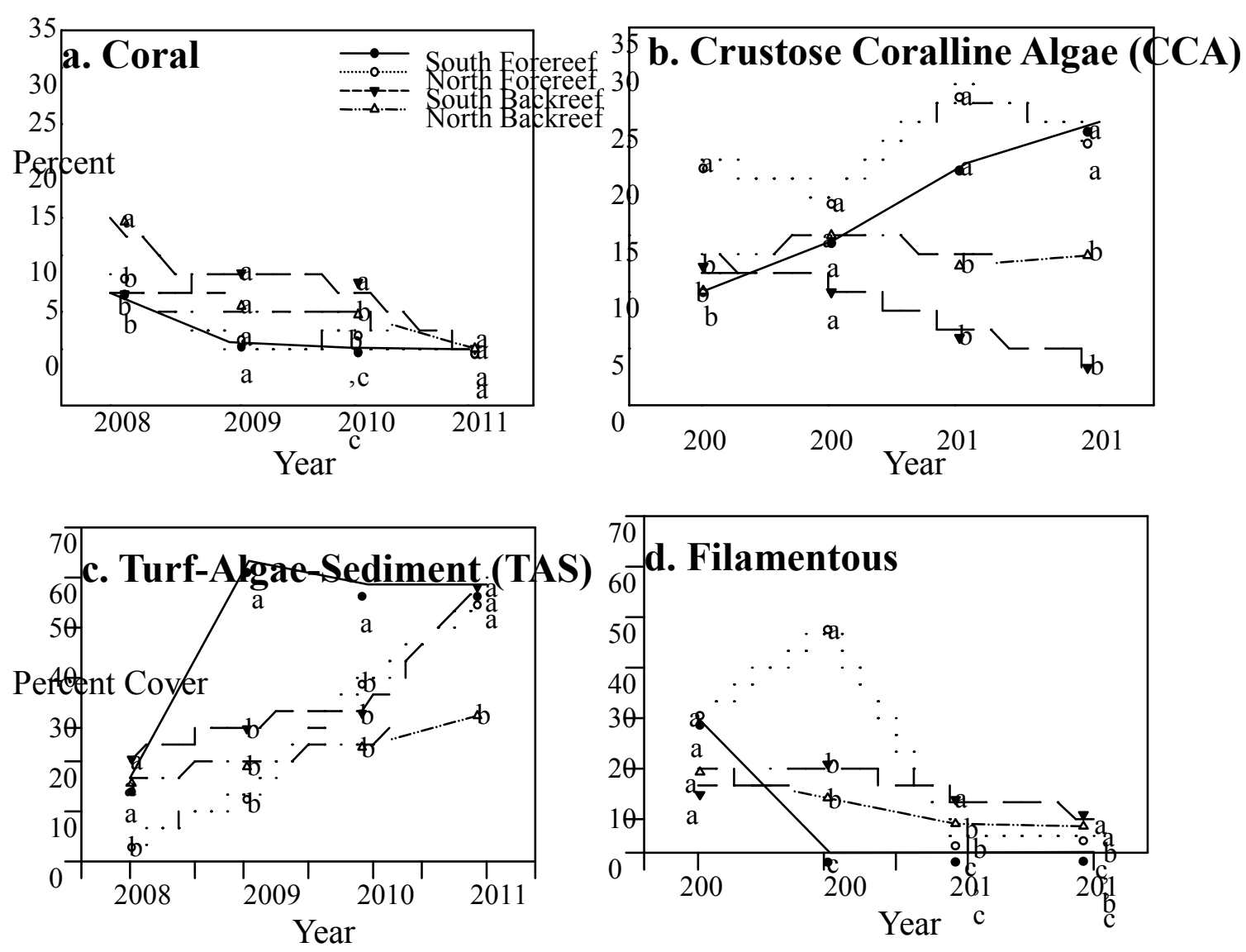


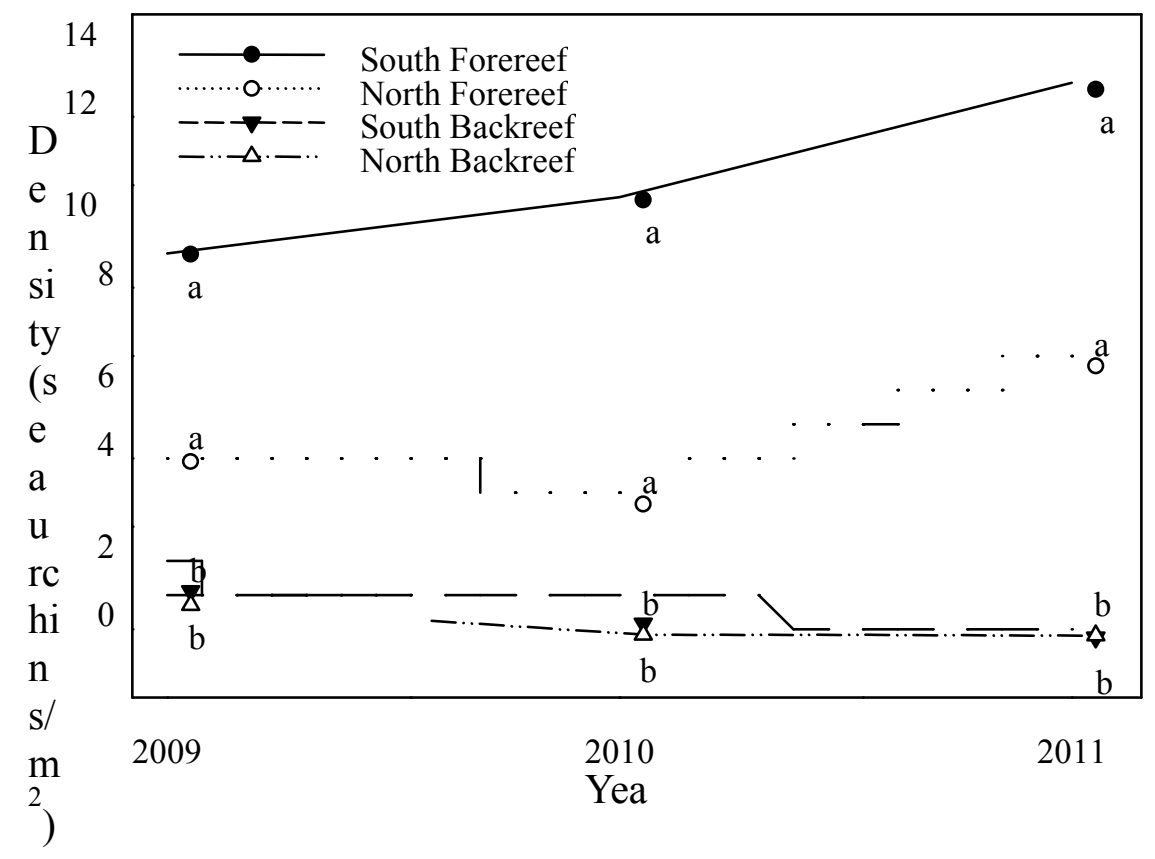


CHAPTER V: Macroalgae genera richness, diversity indices and nutrient content relationships over time on an impacted Caribbean coral reef

\section{Abstract}

Examination of benthic functional groups previously studied (Chapter IV) determined that reefs in Akumal were turf-algae-sediment (TAS) dominated and Diadema antillarum densities have recovered to densities comparable to other regions within the Caribbean. As disturbance by herbivores can drive changes to macroalgae diversity, I monitored macroalgae generic richness and diversity indices in conjunction with nutrient content as a proxy to productivity to determine how these factors may impact macroalgae diversity. Using the dynamic equilibrium model, I hypothesized that in conditions of high nutrient availability, I would expect higher diversity and richness at higher D. antillarum density sites (North Backreef and South Backreef, Chapter IV) than those sites with lower D. antillarum densities (North Forereef and South Forereef). Detailed studies on macroalgae diversity and nutrient content, particularly within the Mesoamerican region, are sparse and data reporting this information is vital for continued work on these dynamics. My results indicate that generic diversity increased for three sites and nutrient content remained enriched throughout the duration of this study. Dominant genera present included Halimeda, Galaxaura, Gelidiella and Dictyota. South Forereef was the only site which decreased in diversity and was also the only site to experience an increase in crustose coralline algae (CCA) during previous studies. Data on nutrient content within the various macroalgae sampled indicate highly variable nitrogen (0.6-3.0 \% DW) and phosphorus content (0.03-0.15\%DW) not previously recorded and emphasizes the importance of continued studies on these macroalgae 
nutrient dynamics. After considering general trends of increasing diversity over the four years of the study for three of the four sites, it may be both TAS and a diverse guild of macroalgae may continue to dominate the Akumal coral reef ecosystem. Introduction

Diversity, richness and evenness are driven by a multitude of factors, the majority and extent of which in marine ecosystems are largely unknown (Stachowicz et al. 2007). Diversity encompasses taxa richness, the number of taxa present and evenness, the relative abundance of taxa within the community. Early research hypothesized that herbivory was important for maintaining diversity of marine plant communities as biomass removal decreases the probability of competitive exclusion (Paine 1966a, 1971, Lubchenco 1978). In further study, the Intermediate Disturbance Hypotheses (IDH) predicts a unimodal relationship between diversity and disturbance (grazing or abiotic forcing): at low disturbance rates, competitive exclusion can lead to community dominance by few superior competitors, but at high disturbance rate, few taxa can persist, such that diversity is at maximum at intermediate levels of disturbance (Paine 1966b, Grime 1973a, Connell 1978, Lubchenco 1978). Complexities to herbivore disturbance arise when differences in herbivore size, feeding modes, food preferences and mobility impact their effect on individual plant taxa (Lubchenco 1978). Primary producer response to herbivory is also an important factor as different competitive abilities for limiting resources and defense mechanisms can determine primary producer prevalence within the habitat (Gaines \& Lubchenco 1982).

Continual nutrient enrichment impacts productivity and also creates a unimodal distribution of organisms as aggressive competitors for space and light displace 
subordinate organisms (Mittelbach et al. 2001, Worm et al. 2002). For macroalgae, effects of enrichment tend to be context-dependent and little is known about the importance of morphological and physiological differences among macroalgae on nutrient content (Fong et al. 2001). In marine ecosystems, some macroalgae (e.g., foliose Chlorophytes) are opportunists with fast nutrient uptake and growth rates reflecting this increased productivity afforded by enrichment (Waite \& Mitchell 1972, Birch et al. 1981, Gordon et al. 1981, Lapointe \& Tenore 1981). There is typically a trade-off between fast-growing colonizers and slow-growing superior competitors (Connell \& Slatyer 1977, Grime 1977), as per-capita nutrient and space availability decrease through a successionary sequence, so that long-lived and slow-growing organisms dominate later successional stages. However, early successional species (e.g., Ulva) can outcompete species occurring during later successional stages under conditions of nutrient enrichment (Lubchenco 1978).

Both productivity (Grime 1973a, Huston 1979) and disturbance (Paine 1966b, Grime 1973a, b, Connell 1978) are central to those ecological theories surrounding our understanding of the factors determining abundance, diversity and distribution of species. In the dynamic equilibrium model, the identity and quantity of genera present can be the result of disturbances and productivity over time (Huston 1979). This model suggests that disturbances increase diversity when productivity is high and decrease diversity when productivity is low. Understanding diversity is important in the context of overall ecosystem status as a macroalgally-rich ecosystem may contain macroalgae of varying tolerances to nutrient limitation or disturbances. The diverse assemblage of macroalgae might then remain dominant as changes to productivity or levels of disturbance occur 
over time (known as the insurance hypothesis (Yachi \& Loreau 1999), provided I have an understanding on how both of these factors may have influenced diversity.

Diversity can be measured at different levels, e.g., species, genus, functional groups, depending on the type of information required to answer the ecological questions being asked. Functional groups can be created which categorize organisms based on body morphology, life history strategy or other traits that may be ecologically relevant to broader ecosystem questions, e.g., macroalgae form functional groups (Littler et al. 1983, Steneck \& Dethier 1994). If an area is being monitored, for instance, to detect an invasive species or conserve an endangered species, species level surveys are necessary but they require specialist training and increased survey time. Species-level comparisons of diversity provide the highest resolution but can be too variable to demonstrate trends (Warwick 1988b, a) while genus or functional group analyses may provide more relevant ecological information (Konar \& Iken 2009). Aggregating species composition data to genus level can provide similar results to functional group data (Konar \& Iken 2009) however attributes determining functional groups can be disputed or vary between researchers and experimental questions. Because it is impossible to disaggregate data collected using functional groupings into species- or genera-specific information after the fact, recording of data in the field should be done at the highest practical level of taxonomic resolution. For marine macroalgae and the difficulty of field identification to the species level, genus level is the more practical choice and provides latitude to functional group assignation of individual taxa. In this manner, data collected at the genus level can not only be useful for those ecological questions being asked during the 
survey, but can also provide important information to questions that arise from the survey results.

Previous survey data (Chapter IV) considered coral reef functional groups such as turf. Because many species of macroalgae are phenotypically plastic, the turf functional group may include multiple genera that are considered frondose macroalgae during other portions of their life cycle (Hay 1981) and may have vastly different impacts on coral reef ecosystem dynamics. The use of these functional groups was useful to answer the ecological questions posed during the previous survey while more specific questions on diversity, evenness and richness require genus-level surveys, the highest level of taxonomic resolution that can be used during in situ identification of macroalgae. It is helpful to consider both functional groups and genus-level information as genus level surveys can be scaled up to the most appropriate functional group and functional groups can give insight into attributes among genera that may be driving differences.

This study builds on conclusions drawn from a previous study (Chapter IV) where monitoring of benthic functional groups indicated that reefs in Akumal were increasingly turf-algae-sediment (TAS) dominated and Diadema antillarum densities were greatest at North Backreef and South Backreef sites. While benthic functional groups can provide information on the overall ecosystem status, a more detailed consideration of macroalgae genera and nutrient content can provide important information on the use of nutrients within the ecosystem and if macroalgae genera are likely to remain dominant through time. The goals of this study were to first complete a record of diversity and nutrient content of the macroalgae genera present within Akumal Bay. This is an important step as there is a paucity of literature reporting diversity and taxon-specific nutrient content in 
the Mesoamerican (but for diversity see Collado-Vides et al. 1998 and for nutrient content see Mutchler and Dunton 2007). I also wanted to understand the drivers to macroalgal diversity (e.g., herbivore disturbance and nutrient content as a proxy for productivity) in the context of Huston's dynamic equilibrium model (1979). I hypothesized that sites where macroalgal productivity was not limited by nutrients, nitrogen and phosphorus content would be above those values indicated as minimum for aquatic marine plants $(0.02 \%$ dry weight phosphorus, $1.2 \%$ dry weight nitrogen, $30: 1$ N:P; Atkinson \& Smith 1992). For those sites with high productivity, I would expect higher diversity and richness at higher $D$. antillarum density sites (North Backreef and South Backreef, Chapter IV) than those sites with lower D. antillarum densities (North Forereef and South Forereef). Diversity would be expected to vary spatially among sites and temporally among years depending on changes in herbivore density and macroalgal productivity (e.g., if macroalgae nutrient content increases, I would expect diversity to increase at sites with higher $D$. antillarum density).

Methodology

Akumal Bay reef is located approximately 300 meters from shore and is characterized by a semi-enclosed lagoon sloping towards the $3-4$ meter deep backreef, a shallow northern and southern reef crest and a $3-4$ meter deep forereef (Figure 1). The reef has low coral cover (maximum 14\%; Chapter IV) with 50\% loss of coral cover over the last twenty years (Harvell et al. 2007) and high fishing pressure (Garcia-Salgado et al. 2008). Four $70 \mathrm{~m}$ by $100 \mathrm{~m}$ locations were targeted (Figure 1) to represent the different areas on Akumal Bay reef, two on the forereef (South Forereef and North Forereef) and 
two on the backreef (South Backreef and North Backreef). Rugosity is significantly higher in backreef than forereef sites (Chapter IV).

From 2008-2011, six to ten haphazardly-chosen locations within each area were selected to place a 30 meter transect line parallel to the reef crest. Macroalgae generic richness was assessed by recording percent cover and identify of all macroalgae genera present within 60-100 random $\mathrm{m}^{2}$ locations along the transect. All efforts were made to identify macroalgae (greater than $3 \mathrm{~cm}$ ) to the genus level. For those specimens that I were unable to identify in the field, samples were taken back to the lab for further identification using Littler \& Litter (2000). Shannon-Weiner diversity, which takes into account richness and evenness, was calculated using PRIMER software (Clarke \& Warwick 2001) with the equation: $H^{\prime}=-\Sigma p_{i} \ln \left(p_{i}\right)$, where $p_{i}$ is the proportional cover of the $i$ th genera along the transect and $\Sigma$ is sum of all $i$ macroalgae genera. Pielou's evenness was calculated as J' $=\mathrm{H}^{\prime} / \log (\mathrm{S})$ using PRIMER software (Clarke \& Warwick 2001). Since macroalgal plants differ in size and it becomes difficult to calculate numbers of 'individuals,' percent cover was used for the proportional data $\left(p_{i}\right)$ to calculate $H^{\prime}$ (Aronson et al. 1994). To determine if there were changes in diversity through the four years of the survey and if diversity different by site, measures of diversity were compared via a two-way ANOVA using SPSS after an examination of standardized residuals determined that data conformed to assumptions regarding normality. Differences between years were determined with post-hoc pairwise comparisons.

Macroalgae tissue samples were collected within the four designated study areas, both inside and outside of sampling quadrats. Samples were discarded when there was 
inadequate biomass (less than 5 grams dry weight) to complete analytical sampling. All samples were gently cleaned of epiphytes, dried to a constant weight at $60^{\circ} \mathrm{C}$ and ground to a fine powder using a mortar and pestle. Samples were analyzed in duplicate for nitrogen content using a $\mathrm{CHN}$ analyzer and for phosphorus using dry-oxidation acidhydrolysis extraction followed by colorimetric analysis. Dry weight elemental content was calculated as (mass of element/dry weight of sample) x 100\%. While some genera were found at multiple sites, Halimeda spp. was the only genus present in multiple sites over the four years. To determine if significant changes occurred over the four years of the survey, data across all sites were compared by year via an ANOVA using SPSS after examination of standardized residuals determined the data conformed to assumptions regarding normality.

Results

Twenty-two different genera were recorded during the surveys from 2008-2011 on Akumal reefs (Table 1). Gelidiella spp., Halimeda spp. and Dictyota spp. were the dominant macroalgae genera. Additional genera were noted on the reef (e.g., Sargassum) but did not fall within the study area. Over time, three of the four sites (North Forereef, South Backreef, North Backreef) experienced a significant increase in Shannon-Weiner diversity and Pielou's evenness while two of the sites had significant changes in richness (decrease in South Forereef and increase in South Backreef). Temporal variation also occurred in macroalgal nutrient content. While nitrogen and phosphorus content significantly increased in Halimeda, the only genera present in multiple sites through all four years, N:P in 2008 was not significantly different than the N:P observed in 2011. For genera not present across multiple sites, samples were largely phosphorus limited 
(South Forereef: Laurencia; North Forereef: Stypopodium; South Backreef: Stypopodium; North Backreef: Caulerpa). For each of these genera present, nitrogen content was Caulerpa $2.5-2.8$ percent dry weight (\% DW), Laurencia $0.8-2.1(\% \mathrm{DW})$ and Stypopodium $1.1-2.0(\%$ DW). Maximum nutrient content was 3.1 (\% nitrogen DW Penicillus) and 0.15 (\% phosphorus DW Caulerpa).

Dominant Chlorophytes included Caulerpa (maximum cover 50\%), Halimeda (maximum cover $60 \%$ ) and Udotea (maximum cover $40 \%$; Table 1). Dominant Rhodophytes included Gelidiella (maximum cover 80\%), Amphiroa (maximum cover $40 \%$ ) and Galaxaura (maximum cover 40\%). Ochrophytes were dominated by Dictyota (maximum cover 60\%). While there was no net change in generic richness for the North Forereef and North Backreef, macroalgal diversity and evenness did increase over time (Figure 2). These sites did not experience a significant change in crustose coralline algae (CCA) while coral cover significant decreased and turf-algal-sediment (TAS) cover increased (Table 2). Generic richness, evenness and diversity decreased significantly in the South Forereef while all parameters increased significantly in the South Backreef. The South Forereef was the only site to experience a significant increase in CCA while the South Backreef significantly decreased CCA. Coral cover significantly decreased and TAS significantly increased at both sites (Table 2).

Nitrogen and phosphorus content significantly increased in Halimeda, the only species present across all years and in multiple sites, while there were no significant changes in N:P of 2008 to 2011, which averaged 65 (Figure 3). Nutrient content in the genera collected was highly variable (Table 3 ) as nitrogen content was $0.6-3.4$ (\% DW) and phosphorus content was $0.03-0.15(\% \mathrm{DW})$. The high spatial and temporal 
variability in genera present do not make statistical comparisons of nutrient content between sites and years feasible.

\section{Discussion}

Conclusions drawn from the benthic functional groups examined previously in this dissertation indicated that reefs in Akumal are turf-algal-sediment (TAS) dominated and coral cover has significantly decreased. During this study, macroalgal diversity indices increased at three of the four sites as predicted by the dynamic equilibrium model (Huston 1979), where disturbance in a high nutrient environment increases diversity. When compared to the close to 100 genera recorded in other portions of the MesoAmerican reef (Collado-Vides et al. 1998), there were less genera found in Akumal during this survey. Although some disparity may be attributed to differences in sampling methodologies or intensities, some genera are less fecund under high nutrient conditions (Diaz-Pulido \& McCook 2005) and may limit the genera present in Akumal to those which can tolerate nutrient-replete conditions. While nitrogen and phosphorus values were highly variable and for Halimeda tracked spatially and temporally, nitrogen and phosphorus content increased significantly and remained above the minimum nutrient content limiting to macroalgal productivity (Atkinson \& Smith 1983, Duarte 1992). When considered in conjunction with previous functional group and herbivory data (Chapter IV), a decline in the algal dominated status does not seem a plausible prediction for Akumal Bay.

In coastal marine ecosystems, nitrogen and phosphorus loading are typically high from anthropogenic point and non-point sources existing in close proximity to these environments (Cloern 2001). Nitrogen:phosphorus above 30 indicate benthic marine 
plant growth is phosphorus-limited and further consideration of nitrogen and phosphorus content is important to determine if specific nutrient content also indicates a limitation to growth (Atkinson \& Smith 1983, Duarte 1992). In Akumal each site had at least one genus present for all four years and, in each of these site/genus combinations, nutrient ratios indicated macroalgae were phosphorus-limited. My data can also be considered in relation to the paucity of data on nutrient content of macroalgae reported for other areas within the Mexican Caribbean. For instance, in Akumal Bay Mutchler and Dunton (2007) reported Halimeda nitrogen values of 1 percent dry weight (\% DW) while Halimeda in Yal Ku Lagoon, Akumal (Chapter II) had nitrogen maximum 1.6 (\% DW). Variability in nutrient content between genera could be caused by differences in morphologies and physiological requirements. Nutrient differences can occur between fleshy forms such as Caulerpa and Avrainvillea when compared to calcified forms such as Halimeda, Udotea and Penicillus (Demes et al. 2010). The calcifying behavior of some genera has an important role in phosphorus absorption and while samples can be decalcified to run analysis, this does not change the mechanism by which certain genera have acquired phosphorus. In this study (Table 3), fleshy Caulerpa nitrogen content was $2.5-3.0(\% \mathrm{DW})$ while calcareous Udotea was $0.09-0.115$ (\% DW). Phosphorus content for Caulerpa was $0.09-0.15(\% \mathrm{DW})$ and for Udotea was $0.07-0.10(\% \mathrm{DW})$. These variations could have been from differences in calcifying behavior. Other differences arise when considering growth forms such as epilithic versus psammophytic forms within the same genus (e.g., Halimeda) as photosynthesis among species is adapted to episodic delivery of nutrients and light limitation (Littler et al. 1988). Differences in growth morphologies between genera can also impact nutrient utilization as rhizophytic 
macroalgae utilize both water column and sediment nutrients, macroalgae with upright thalli and open-branching patterns utilize mostly water column nutrients and mat-forming species utilize mostly sediment nutrients (Fong et al. 2001). Those macroalgae genera morphologies characterized by high surface area-to-volume ratios and therefore growth rates may also have higher concentrations of nutrients than those slower growing genera (Bracken \& Nielsen 2004). This study is important because it provides a more inclusive report of macroalgae nutrient content from which further work on the taxon-specific responses of macroalgae to nutrient availability can be made.

On the South Forereef, generic diversity, abundance and richness significantly decreased over the four years surveyed as the calcareous green genera Halimeda and Udotea were lost. The South Forereef experiences higher wave disturbance than backreef sites, yet this is the only site which did not follow my hypothesized results based on the dynamic equilibrium model (Huston 1979). Considering this data in conjunction with the increase in CCA and TAS cover found during previous studies, the increase in these functional groups may have increased competition for space needed for macroalgal propagule settlement and growth. The South Backreef was the only site to significantly increase genera richness through the addition of the genera Avrainvillea, Bryothamnion, Padina and Turbinaria. Some of these macroalgae do provide a more complex canopy structure (Steneck \& Dethier 1994), which could provide refuge for other macroalgae genera as herbivores avoid highly dense macroalgal stands (Hoey \& Bellwood 2011). Changes in macroalgal diversity could have also been impacted by the significantly higher rugosity provided at the South Backreef site than forereef sites. Structural complexity provides increased space for macroalgal propagule settlement, which could 
drive the measured increases in diversity. The significant reduction in crustose coralline algae cover on the South Backreef could have also freed suitable substrate for settlement by new genera of macroalgae and the expansion of cover by the existing genera. While there was not an overall change in richness on North Forereef and North Backreef sites, genera diversity and evenness did significantly increase over time. Both of these sites experienced significant increases in TAS cover and no net change in the amount of CCA cover for the four years of the study. It is interesting to note that this is counter to what occurred on the south sites, where significant changes in CCA cover occurred when significant changes in genera richness occurred. The decrease in macroalgal genera richness where CCA was highest may have been caused by the shedding mechanism CCA utilizes to remove the epibionts attempting to recruit onto the thallus surface (Keats et al. 1997). As macroalgae are limited by available propagules and existing macroalgae fragmentation (Sousa 1985), the increasing cover by TAS mats may provide a source of these propagules and vegetative propagation for the persistence of existing genera (Airoldi 1998) while preventing the settlement or establishment of new genera.

In addition to nutrients, echinoid grazer disturbance was recorded within the sites and described in Chapter IV. In the South Forereef, the site with significantly higher densities of Echinometra lucunter, positive correlations between this echinoid and CCA cover may have contributed to decreased diversity through the CCA thallus shedding mechanism described previously. The decline in diversity at this site is counter to My hypothesis, which predicts that the disturbance caused by E. lucunter grazing would increase diversity in the high nutrient environment. In the North Forereef, D. antillarum was significantly lower than backreef sites and $E$. lucunter densities were significantly 
lower than the South Forereef sites, yet diversity still increased. There is some disparity between the disturbances experienced at these sites which may be contributing to the inconsistencies in my measures of diversity. This study would greatly benefit from direct manipulation of the echinoids in order to elucidate some of these dynamics.

As Akumal's reefs are TAS dominated and macroalgae generic diversity has increased at the majority of sites, a reduction in macroalgal cvoer does not seem a practical prediction that can be supported within this ecosystem. Further, macroalgal identity, richness and diversity reduce temporal fluctuations in community biomass (Bruno et al. 2005, Bruno et al. 2006, Stachowicz et al. 2007) and can increase the stability of a macroalgal-dominated ecosystem. After considering general trends of increasing diversity over the four years of the study for three of the four sites, it may be both TAS and a diverse guild of macroalgae may continue to dominate the Akumal coral reef ecosystem. 
Table 1: Macroalgal genera inventory for Akumal Bay, Quintana Roo, Mexico

\begin{tabular}{|c|c|c|c|}
\hline Division & Genera & $\begin{array}{c}\text { Maximum } \\
\text { Percent } \\
\text { Cover }\end{array}$ & $\begin{array}{l}\text { Mean Percent Cover } \pm \mathrm{SE} \\
\text { (across all four sites) }\end{array}$ \\
\hline Chlorophyta & Avrainvillea & 1 & $0.00 \pm 0.00$ \\
\hline \multirow[b]{10}{*}{ Rhodophyta } & Caulerpa spp. & 50 & $0.75 \pm 0.10$ \\
\hline & Dictyosphaeria cavernosa & 20 & $0.16 \pm 0.04$ \\
\hline & Halimeda spp. & 60 & $3.97 \pm 0.21$ \\
\hline & Neomeris annulata & 10 & $0.12 \pm 0.02$ \\
\hline & Penicillus spp. & 30 & $0.08 \pm 0.04$ \\
\hline & Rhipocephalus & 10 & $0.03 \pm 0.02$ \\
\hline & Udotea spp. & 40 & $0.38 \pm 0.07$ \\
\hline & Valonia ventricosa & 10 & $0.06 \pm 0.01$ \\
\hline & Green other & 10 & $0.17 \pm 0.02$ \\
\hline & Acanthophora spicifera & 1 & $0.00 \pm 0.00$ \\
\hline \multirow{13}{*}{ Ochrophyta } & Amphiroa & 40 & $0.61 \pm 0.09$ \\
\hline & Bryothamnion & 30 & $0.16 \pm 0.05$ \\
\hline & Coelothrix irregularis & 20 & $0.17 \pm 0.04$ \\
\hline & Galaxaura & 40 & $1.77 \pm 0.14$ \\
\hline & Jania & 20 & $0.51 \pm 0.06$ \\
\hline & Gelidiella & 80 & $1.05 \pm 0.19$ \\
\hline & Laurencia spp. & 30 & $0.27 \pm 0.05$ \\
\hline & Liagora & 20 & $0.06 \pm 0.03$ \\
\hline & Dictyota & 60 & $3.69 \pm 0.22$ \\
\hline & Lobophora & 20 & $0.04 \pm 0.02$ \\
\hline & Padina & 25 & $0.35 \pm 0.05$ \\
\hline & Stypopodium & 15 & $0.36 \pm 0.04$ \\
\hline & Turbinaria & 10 & $0.05 \pm 0.02$ \\
\hline
\end{tabular}


Table 2: Change in benthic cover parameters and diversity indices over four years with average densities of echinoids $\left(\# / \mathrm{m}^{2}\right)(\uparrow$ indicates significant increase in four years, $\downarrow$ indicates significant decrease in four years, -- indicates no significant change in four years)

\begin{tabular}{|c|c|c|c|c|c|c|c|c|c|}
\hline Site & CCA & Coral & TAS & Turf & Diversity & $\begin{array}{c}\text { Even } \\
\text { ness }\end{array}$ & $\begin{array}{c}\text { Rich } \\
\text { ness }\end{array}$ & $\begin{array}{c}\text { Diadema } \\
\text { antillarum }\end{array}$ & $\begin{array}{c}\text { Echinometra } \\
\text { lucunter }\end{array}$ \\
\hline $\begin{array}{c}\text { South } \\
\text { Forereef }\end{array}$ & $\uparrow$ & $\downarrow$ & $\uparrow$ & $\downarrow$ & $\downarrow$ & $\downarrow$ & $\downarrow$ & 0.2 & 10.5 \\
\hline $\begin{array}{c}\text { North } \\
\text { Forereef }\end{array}$ & -- & $\downarrow$ & $\uparrow$ & $\downarrow$ & $\uparrow$ & $\uparrow$ & -- & 0.2 & 4.5 \\
\hline $\begin{array}{c}\text { South } \\
\text { Backreef }\end{array}$ & $\downarrow$ & $\downarrow$ & $\uparrow$ & - & $\uparrow$ & $\uparrow$ & $\uparrow$ & 1.3 & 0.5 \\
\hline $\begin{array}{c}\text { North } \\
\text { Backreef }\end{array}$ & -- & $\downarrow$ & $\uparrow$ & $\downarrow$ & $\uparrow$ & $\uparrow$ & -- & 1.1 & 0.3 \\
\hline
\end{tabular}


Table 3: N:P, nitrogen and phosphorus content for select macroalgae within Akumal

Bay, Quintana Roo, Mexico. Nitrogen and phosphorus values are percent dry weight and $\mathrm{N}: \mathrm{P}$ is expressed as the molar ratio.

\begin{tabular}{|c|c|c|c|c|}
\hline 2008 & Genus & $\mathbf{N}$ & $\mathbf{P}$ & N:P \\
\hline \multirow{3}{*}{ South Forereef } & Laurencia & 0.8 & 0.07 & 25 \\
\hline & Rhipocephalus & 1.0 & 0.03 & 70 \\
\hline & Dictyota & 1.4 & 0.07 & 45 \\
\hline \multirow[t]{6}{*}{ North Forereef } & Dictyota & 1.4 & 0.06 & 50 \\
\hline & Halimeda & 1.3 & 0.03 & 85 \\
\hline & Jania & 0.8 & 0.07 & 27 \\
\hline & Liagora & 0.8 & 0.03 & 75 \\
\hline & Rhipocephalus & 1.2 & 0.04 & 68 \\
\hline & Stypopodium & 1.5 & 0.07 & 48 \\
\hline \multirow[t]{7}{*}{ South Backreef } & Caulerpa & 2.5 & 0.12 & 47 \\
\hline & Dictyota & 1.3 & 0.04 & 81 \\
\hline & Galaxaura & 1.1 & 0.06 & 39 \\
\hline & Halimeda & 1.1 & 0.03 & 72 \\
\hline & Padina & 2.7 & 0.06 & 92 \\
\hline & Stypopodium & 1.1 & 0.04 & 68 \\
\hline & Udotea & 2.1 & 0.08 & 59 \\
\hline \multirow[t]{6}{*}{ North Backreef } & Caulerpa & 2.6 & 0.09 & 65 \\
\hline & Dictyota & 1.7 & 0.07 & 56 \\
\hline & Halimeda & 0.6 & 0.04 & 30 \\
\hline & Penicillus & 1.3 & 0.04 & 73 \\
\hline & Stypopodium & 1.4 & 0.03 & 95 \\
\hline & Udotea & 2.1 & 0.08 & 59 \\
\hline
\end{tabular}

\begin{tabular}{|l|l|c|c|c|}
\multicolumn{1}{c}{2009 Genus } & N & \multicolumn{1}{c|}{ P } & N:P \\
\cline { 2 - 5 } South Forereef & Caulerpa & 3.0 & 0.12 & 54 \\
\cline { 2 - 5 } & Halimeda & 2.4 & 0.08 & 67 \\
\cline { 2 - 5 } & Laurencia & 2.1 & 0.06 & 74 \\
\cline { 2 - 5 } Stypopodium & 1.2 & 0.04 & 73 \\
\cline { 2 - 5 } & Dictyota & 1.7 & 0.05 & 78 \\
\cline { 2 - 5 } & Galaxaura & 1.0 & 0.03 & 71 \\
\cline { 2 - 5 } & Halimeda & 1.7 & 0.06 & 66 \\
\cline { 2 - 5 } & Liagora & 1.1 & 0.03 & 71 \\
\cline { 2 - 5 } & Stypopodium & 1.3 & 0.04 & 65 \\
\cline { 2 - 5 } & Caulerpa & 2.9 & 0.13 & 52 \\
\cline { 2 - 5 } & Galaxaura & 1.2 & 0.03 & 75 \\
\cline { 2 - 5 } & Halimeda & 0.9 & 0.04 & 49 \\
\cline { 2 - 5 } & Laurencia & 2.3 & 0.07 & 75 \\
\cline { 2 - 5 } & Stypopodium & 1.6 & 0.05 & 76 \\
\cline { 2 - 5 } & Udotea & 1.7 & 0.07 & 56 \\
\cline { 2 - 5 } & & & \multicolumn{1}{|c}{} &
\end{tabular}


North Backreef

\begin{tabular}{|l|c|c|c|} 
Caulerpa & 2.7 & 0.11 & 56 \\
\hline Halimeda & 1.9 & 0.06 & 76 \\
\hline Laurencia & 1.2 & 0.05 & 53 \\
\hline Penicillus & 3.1 & 0.09 & 79 \\
\hline Rhipocephalus & 1.7 & 0.07 & 56 \\
\hline Stypopodium & 1.5 & 0.05 & 67 \\
\hline Udotea & 2.2 & 0.10 & 51 \\
\hline
\end{tabular}

2010

South Forereef

North Forereef

South Backreef

\begin{tabular}{|l|c|c|c|}
\multicolumn{1}{c}{ Genus } & \multicolumn{1}{c}{ N } & \multicolumn{1}{c|}{ N } & N:P \\
\hline Laurencia & 2.1 & 0.06 & 82 \\
\hline Galaxaura & 1.1 & 0.04 & 56 \\
\hline Halimeda & 2.2 & 0.07 & 68 \\
\hline Rhipocephalus & 1.8 & 0.05 & 76 \\
\hline Stypopodium & 1.6 & 0.04 & 80 \\
\hline Galaxaura & 1.3 & 0.04 & 70 \\
\hline Halimeda & 1.1 & 0.05 & 51 \\
\hline Stypopodium & 1.7 & 0.07 & 57 \\
\hline Bryothamnion & 3.0 & 0.06 & 112 \\
\hline Caulerpa & 2.8 & 0.15 & 41 \\
\hline Dictyota & 2.2 & 0.07 & 70 \\
\hline Halimeda & 1.9 & 0.06 & 69 \\
\hline Laurencia & 2.3 & 0.06 & 92 \\
\hline Penicillus & 2.7 & 0.11 & 58 \\
\hline Rhipocephalus & 2.2 & 0.07 & 72 \\
\hline Stypopodium & 2.3 & 0.06 & 85 \\
\hline Turbinaria & 1.0 & 0.04 & 52 \\
\hline Udotea & 2.3 & 0.10 & 51 \\
\hline
\end{tabular}

North Backreef

2011

South Forereef

North Forereef

South Backreef

\begin{tabular}{|l|c|c|c|}
\multicolumn{1}{c}{ Genus } & \multicolumn{1}{c}{ N } & \multicolumn{1}{c|}{ N:P } \\
\hline Laurencia & 1.9 & 0.06 & 69 \\
\hline Dictyota & 1.5 & 0.06 & 54 \\
\hline Galaxaura & 1.2 & 0.03 & 78 \\
\hline Halimeda & 2.3 & 0.06 & 79 \\
\hline Laurencia & 1.1 & 0.05 & 53 \\
\hline Stypopodium & 2.0 & 0.05 & 82 \\
\hline Caulerpa & 2.7 & 0.15 & 40 \\
\hline Dictyota & 1.8 & 0.05 & 79 \\
\hline Galaxaura & 1.1 & 0.03 & 99 \\
\hline Halimeda & 1.1 & 0.04 & 56 \\
\hline Laurencia & 1.8 & 0.06 & 67 \\
\hline Stypopodium & 1.3 & 0.04 & 76 \\
\hline Turbinaria & 1.1 & 0.04 & 63 \\
\hline Udotea & 2.5 & 0.09 & 61 \\
\hline Caulerpa & 2.5 & 0.11 & 54 \\
\hline Dictyota & 1.1 & 0.05 & 48 \\
\hline Galaxaura & 1.0 & 0.03 & 76 \\
\hline Halimeda & 2.0 & 0.06 & 73 \\
\hline
\end{tabular}

North Backreef 


\begin{tabular}{|l|c|c|c|}
\hline Laurencia & 1.8 & 0.06 & 67 \\
\hline Penicillus & 3.4 & 0.07 & 103 \\
\hline Rhipocephalus & 1.8 & 0.05 & 75 \\
\hline Stypopodium & 1.4 & 0.03 & 96 \\
\hline Turbinaria & 0.9 & 0.03 & 69 \\
\hline Udotea & 2.6 & 0.09 & 66 \\
\hline
\end{tabular}


Figure 1: Map of Akumal Bay, Quintana Roo, Mexico (Latitude: 20²3’45” N Longitude: $87^{\circ} 18^{\prime} 52^{\prime}$ W W. Study sites indicated by boxes ( SF = South Forereef, NF = North Forereef, $\mathrm{SB}=$ South Backreef, NB = North Backreef).

Figure 2a-c: Shannon-Weiner diversity $\left(\mathrm{H}^{\prime}\right)$, species richness (d) and evenness (J) for all four sites from 2008-2011 in Akumal Bay. Letters indicate significant difference at each site among years.

Figure 3a-c: Nitrogen and phosphorus content (a) and N:P (b) of Halimeda spp. DW: dry weight. Significant differences were assessed with an ANOVA across all sites to detect differences among years. Letters indicate significant difference among years. 


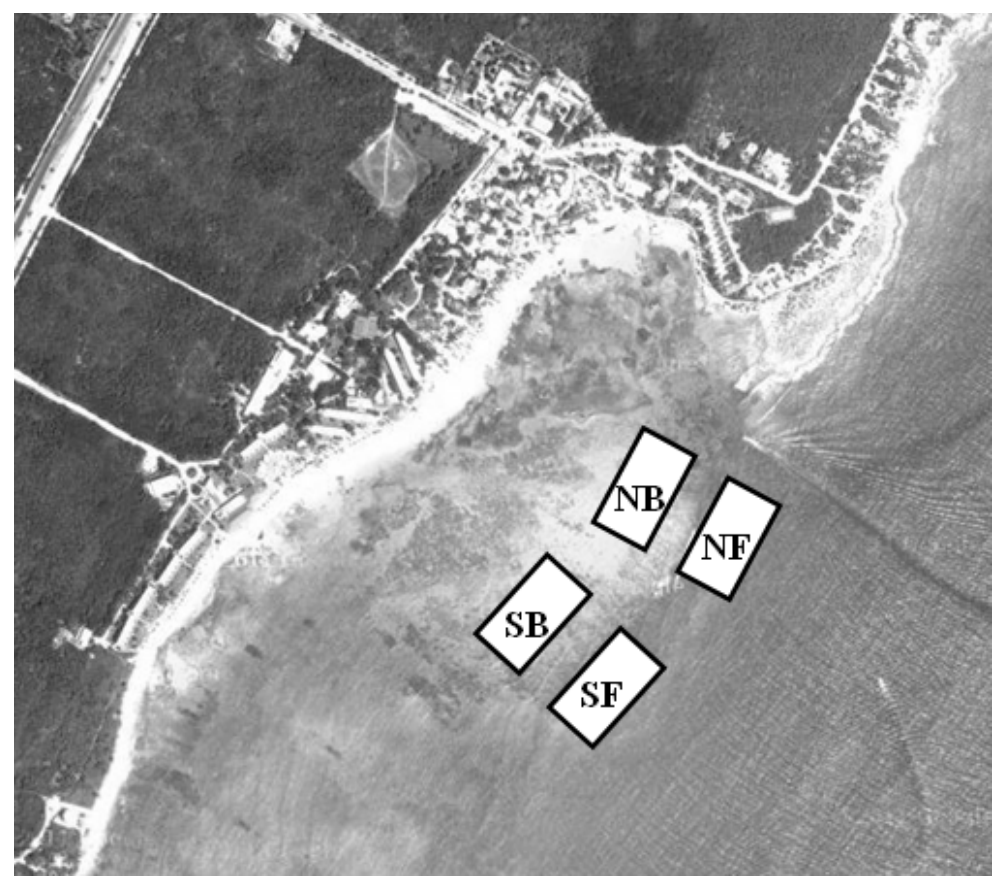



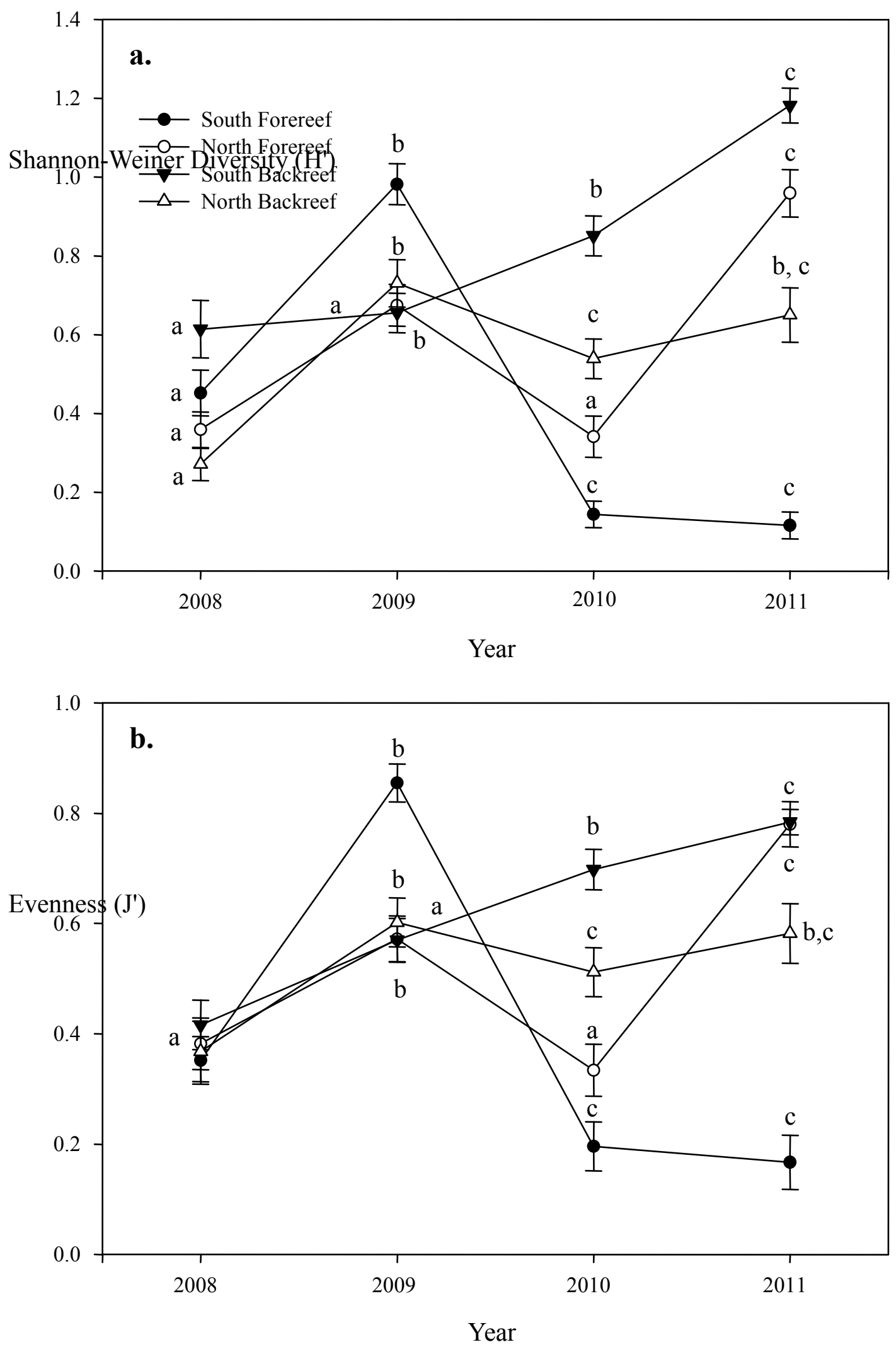


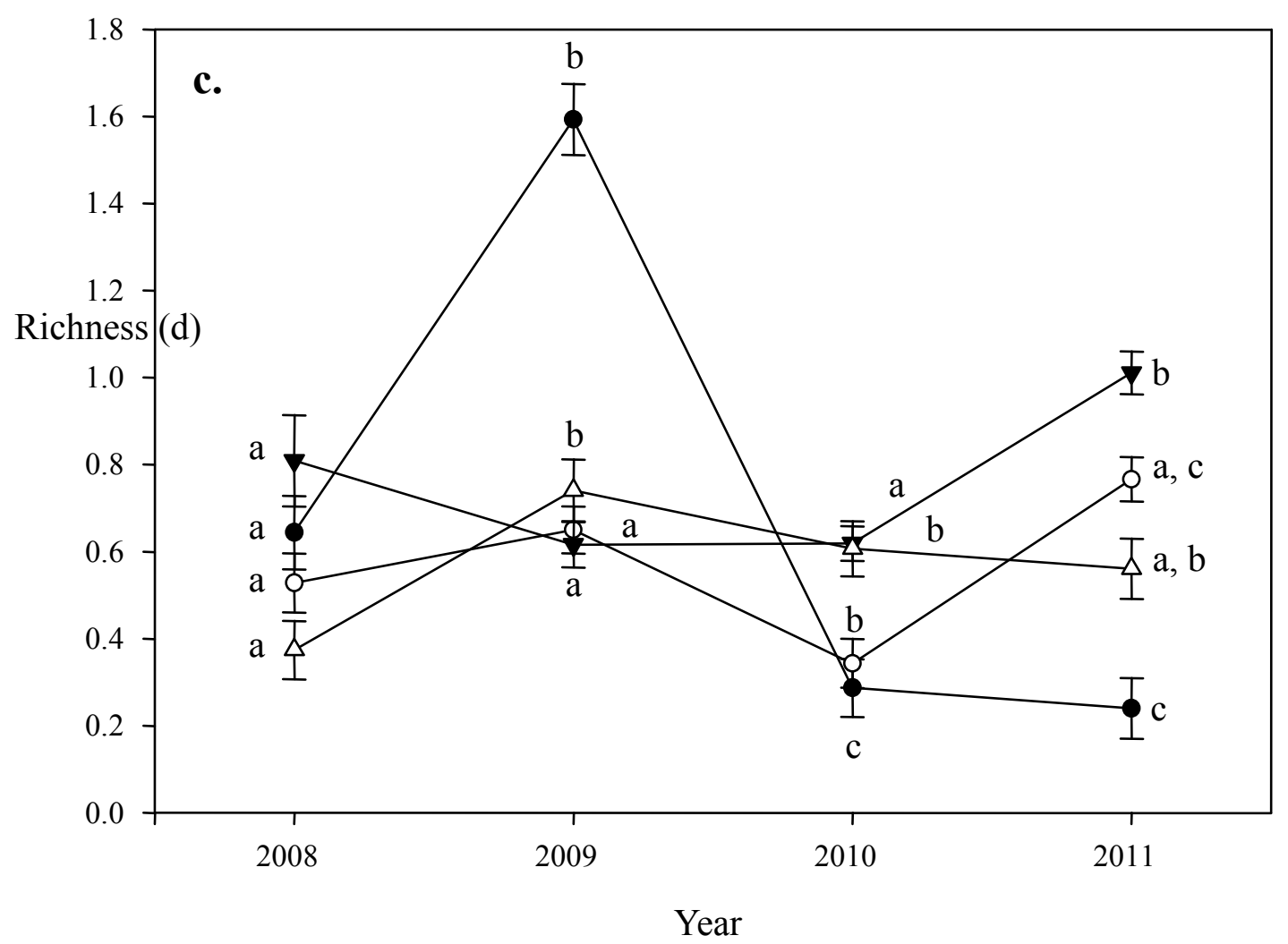



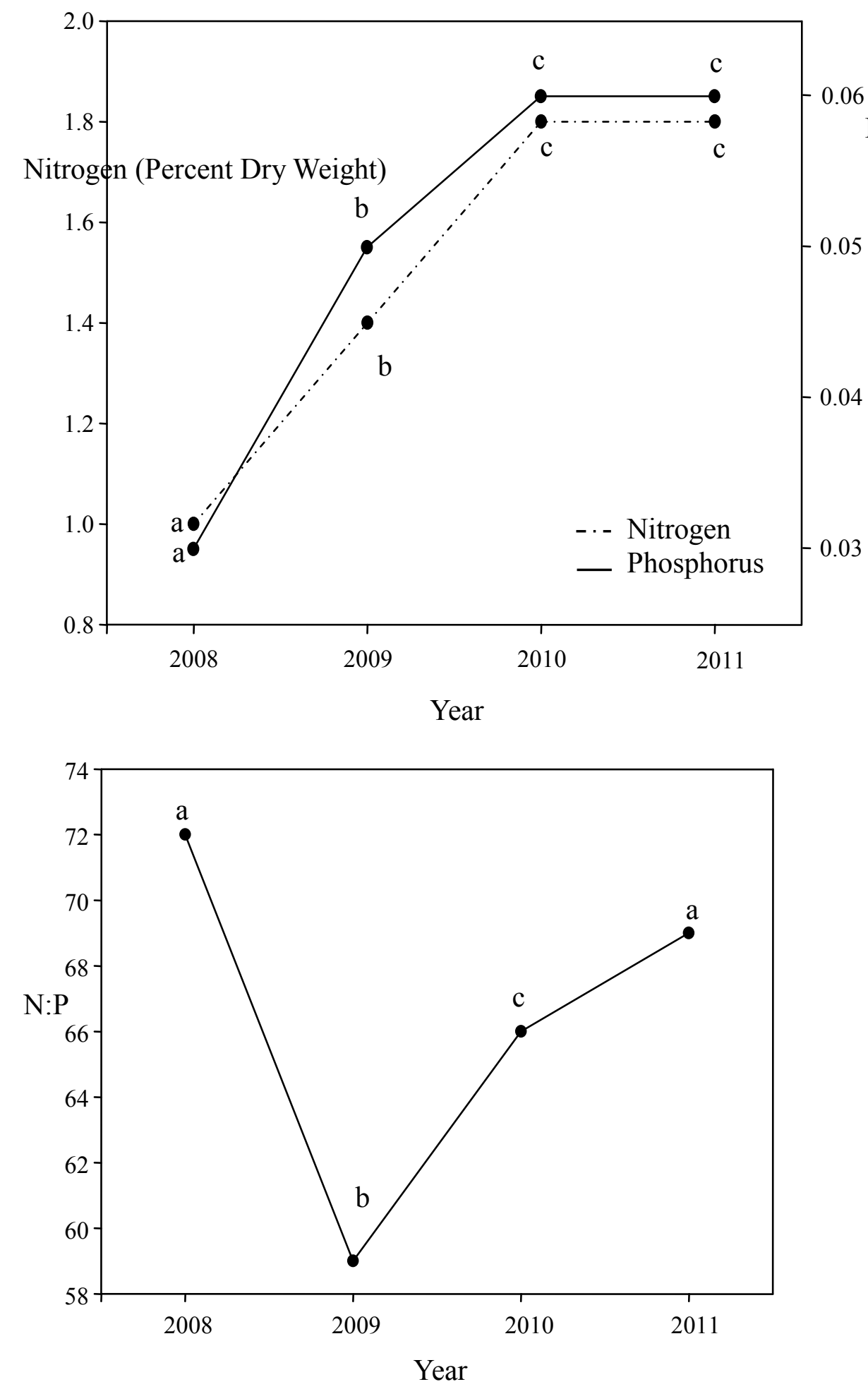


\section{CHAPTER VI: Conclusion}

This study provides valuable insight into the variable effects of herbivores and nutrients on primary producers within a tropical coastal ecosystem. In Chapter II, nitrogen and phosphorus tissue content in both active and passive macroalgal bioindicators supported the designation of the Akumal region as nutrient replete. These results support the findings of previous research in the region using seagrass, octocoral and water samples as tested for anthropogenic nutrients (Carruthers et al. 2005, Baker et al. 2007, Mutchler et al. 2007, Metcalfe et al. 2011). Only in 2010 did isotopic data from the bioassay of Acanthophora spicifera indicate a decrease in signature from source, which was corroborated with nitrogen content data. In 2009 this trend was lacking in both isotopic and nitrogen content data as a peak in nitrogen and $\delta^{15} \mathrm{~N}$ occurred at middistance. Trends in isotopic and nitrogen content of passive bioindicators did not correlate with each other during any year or for any genera. There appears to be a decoupling of the $\delta^{15} \mathrm{~N}$ and nitrogen content signatures indicating that processes occurring in the benthos may be altering availability of these nutrients. Studies are lacking which consider both active and passive bioindicators in the same system and over more than one sampling event. In general, data from this study establish the Akumal system is nutrient replete and macroalgae continue to be effective bioindicators of this high nutrient availability. However, if specific questions regarding nutrient dilution from source are required, as would be the case for marine park managers who seek to identify and reduced anthropogenic loading, active bioassay methodology could more accurately reflect water column nutrients. Higher spatial and temporal resolution is desirable to further utilize macroalgae as bioindicators and resolve variability found 
during this study. This research emphasizes the importance of understanding limitations and confounding factors to the utilization and interpretation of bioindicator data. In any context, understanding the role and response of different macroalgae to this high nutrient availability is important for determining the likelihood that eutrophication will drive a regime shifts to a macroalgae dominated state.

Using this determination of the Akumal region as nutrient replete, in Chapter III I evaluated the impact of green sea turtles, Chelonia mydas, and herbivorous fish grazing on seagrass bed structure and ecosystem resilience under stressors of herbivory and enrichment. Data on seagrass patches grazed by C. mydas demonstrated that nutrient and soluble carbohydrate content were not predictive of patch abandonment, contrary to current theories (Thayer et al. 1984, Moran \& Bjorndal 2007, Fourqurean et al. 2010). Higher nutrient content aboveground (carbon, nitrogen and phosphorus) and lower belowground (soluble carbohydrates) did follow previously reported trends in other grazed areas when compared to ungrazed areas. As in most ecological studies, increased spatial and temporal data as well as manipulative experimentation may further elucidate patterns. However, this study serves as an excellent platform from which to promote an understanding on the dynamics of herbivores in eutrophic ecosystems, a pairing not often considered (unlike peanut butter and jelly or beer and salty nuts). By completing a measurative study rather than a manipulation to mimic the behavior of these important mesograzers, I have provided evidence against a current hypothesis regarding rhizome carbohydrates and have opened a window for further study in this arena. 
To revisit the conceptual model presented in the introduction, I propose a revised model (Figure 1) where eutrophication shifts the Akumal seagrass ecosystem to a highly epiphytized state, which is reversed by fish or turtle herbivory. The seagrass system shifts to a further degraded state when either herbivores are lost and the area is ungrazed or alternatively, when there are too many herbivores and continual herbivory shifts the system to bare sand. My research recorded evidence of this further degraded state in those fish grazed plots with much thinner leaves and less seagrass diversity. I would expect that over time, these areas would become completely devoid of seagrass and become sand barrens.

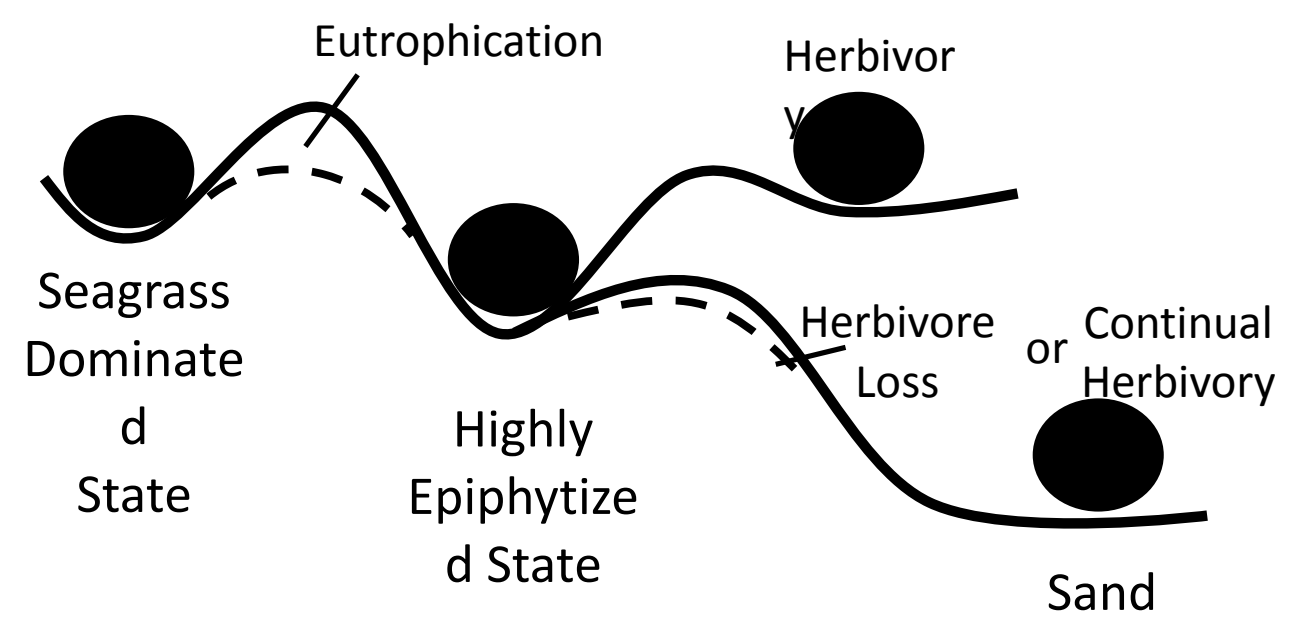

Figure 1: Conceptual model indicating the drivers to shifts within the seagrass ecosystem of Akumal Bay, Quintana Roo, Mexico. Dashed lines indicate the decreased resilience caused by the drivers eutrophication, herbivory and herbivore loss or continual herbivory.

To revisit the grazer disturbance model as I outlined in the Introduction, I propose some modifications based on the results of my research (Figure 2). While the original 
model theorized it was the decline in soluble carbohydrates (dashed line) with increasing grazing intensity which caused the seagrass patch abandonment, my data suggest that it is the decline in biomass and the associated giving up density (Brown 1988), which cues this abandonment. This is the first application of this giving up density theory to the marine environment and provides an exciting platform for further work in the arena of turtle grazing behavior.

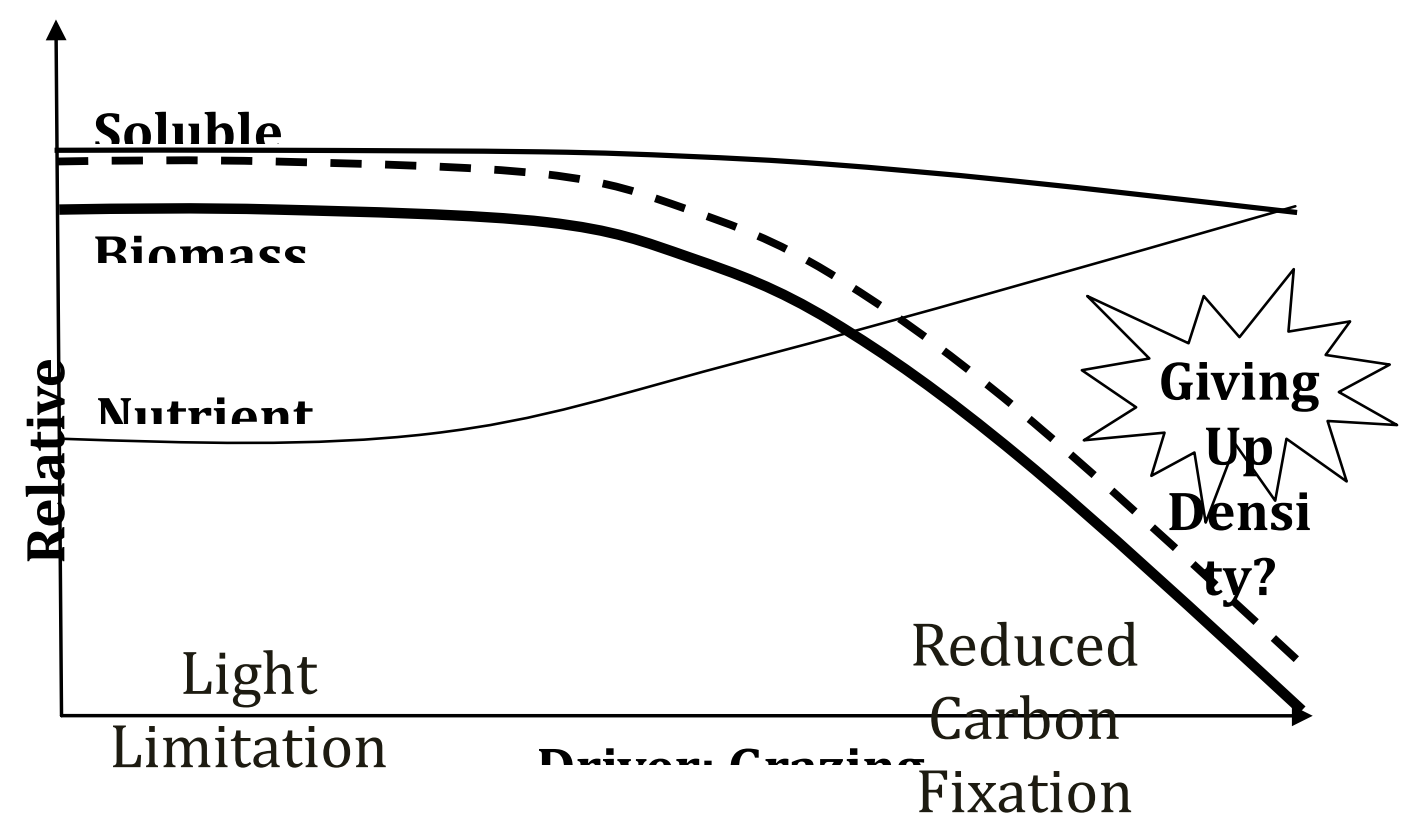

Figure 2: Grazer disturbance model for Akumal seagrass ecosystems. Low grazing intensity leads to light limited seagrasses with higher soluble carbohydrate content relative to aboveground nutrient content. High grazing intensity results in reduced carbon fixation and an increase in relative nutrient content of aboveground nutrient tissue and significantly less soluble carbohydrates (solid line as opposed to originally theorized dashed line). Biomass may be the important driver to seagrass patch abandonment as a potential giving up density is reached at high grazing intensities. 
In a similar manner to herbivores in seagrass beds, in Chapter IV I considered herbivorous long-spined sea urchins, Diadema antillarum, as they consumed macroalgal biomass and influenced the dominant state of the coral reef in Akumal. Although densities of adult $D$. antillarum were comparable to other regions of the Caribbean, declines in coral cover and increases in turf-algal-sediment (TAS) over the four years of this study may be evidence that even a population of this important herbivore cannot prevent the decline of a reef with high nutrient availability. Similar to data published elsewhere, D. antillarum densities correlated positively with coral and crustose coralline algae (CCA) cover in the backreef sites where sea urchin densities were higher. These positive correlations and comparable sea urchin densities are important to consider in the context of a marine park manager utilizing data to predict ecosystem trajectory. If this study had been completed in 2008 only, the predicted trajectory would have considered densities of $D$. antillarum reducing macroalgal cover and a feasible coral recovery. However, when considering the trend in sea urchin populations and functional groups over four years, a different prediction occurs. On Akumal Bay's reefs, the high cover by TAS and the decline in coral cover indicate the system will likely remain algal dominated and a shift to coral dominance is unlikely.

To revisit the conceptual model presented in the introduction, I propose a revised model (Figure 3) where more specific information can be utilized to map the phase shifts that have occurred on Akumal coral reefs. In 1998, the area experienced both hurricane damage and El Niño bleaching followed by the massive mortality of $D$. antillarum. With the coral reef ecosystem in a macroalgae dominated state, further anthropogenic stressors such as nutrients and overfishing as well as incidences of disease have shifted the 
community to one which is dominated by TAS. My research recorded the persistence of this TAS dominated state over time despite the presence of an echinoid population. The positive feedbacks to this TAS dominated state may have to do with the Allee effect as it reduces $D$. antillarum recovery rates, reduced reef rugosity as it restricts spatial distribution of echinoids and the suppression of herbivory that occurs with the high amounts of sediment incorporated into the TAS mats. My research is the first to record this alternative TAS-dominated state and its persistence over time when modeled scenarios would predict a decrease in macroalgal cover (Mumby et al. 2006).

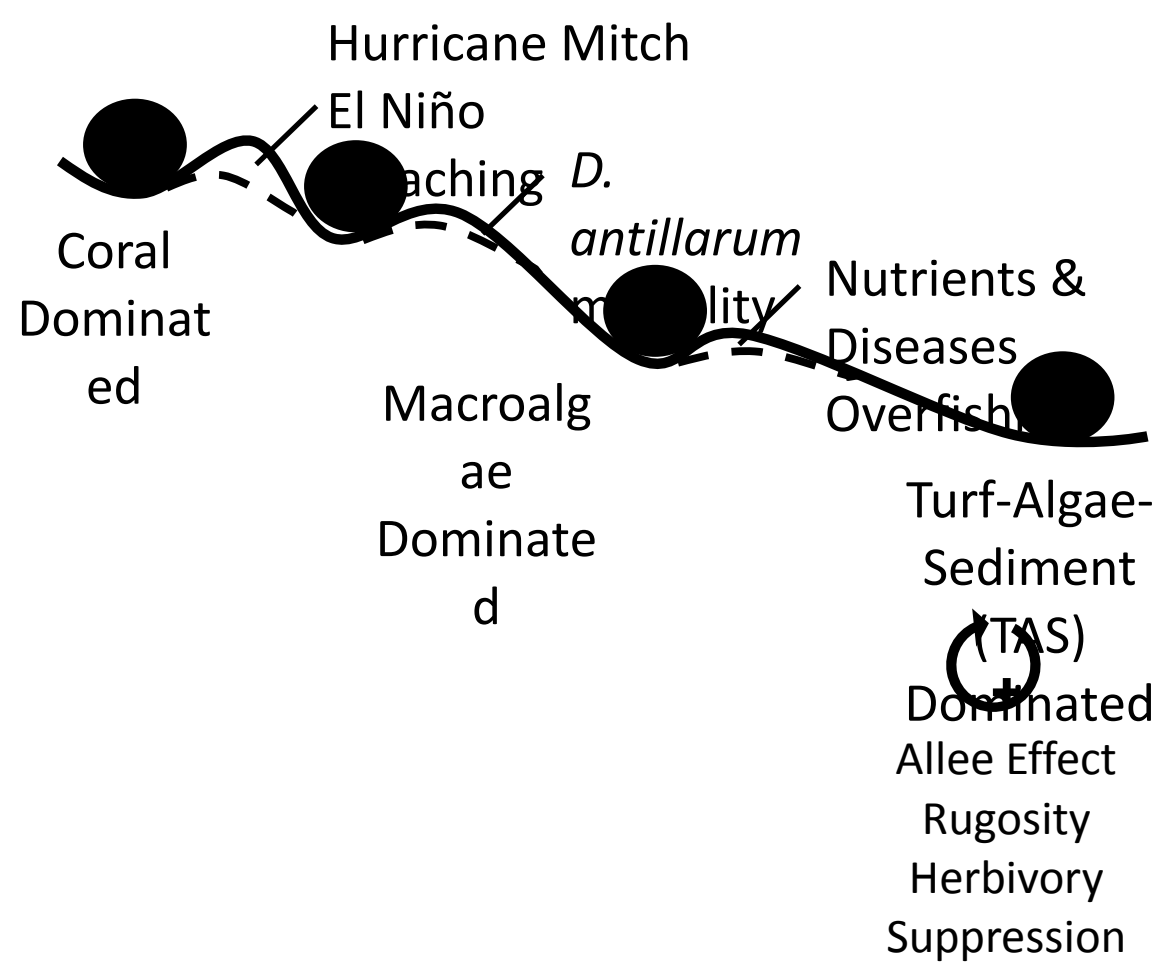

Figure 3: Conceptual model indicating the drivers to shifts within the coral reef ecosystem of Akumal Bay, Quintana Roo, Mexico. Dashed lines indicate the decreased resilience caused by drivers and the circular arrow with a plus sign indicates positive feedbacks to the TAS dominated state. 
To revisit the grazer disturbance model as I outlined in the Introduction, I propose some modifications based on the results of my research (Figure 4). While the original model theorized turf and frondose macroalgae would decline with increased grazing intensity (dashed line), these macroalgal covers were largely absent in Akumal. Instead, TAS was present and dominated at sites regardless of grazing intensity. The original model theorized that either coral or CCA would increase with grazing intensity, depending on nutrient availability. In Akumal, a eutrophic system with high nutrient availability, I did record the expected result of increased CCA however these covers did not dominate, which has important ecological ramifications for marine park mangers hoping this cover will increase with echinoid recovery.

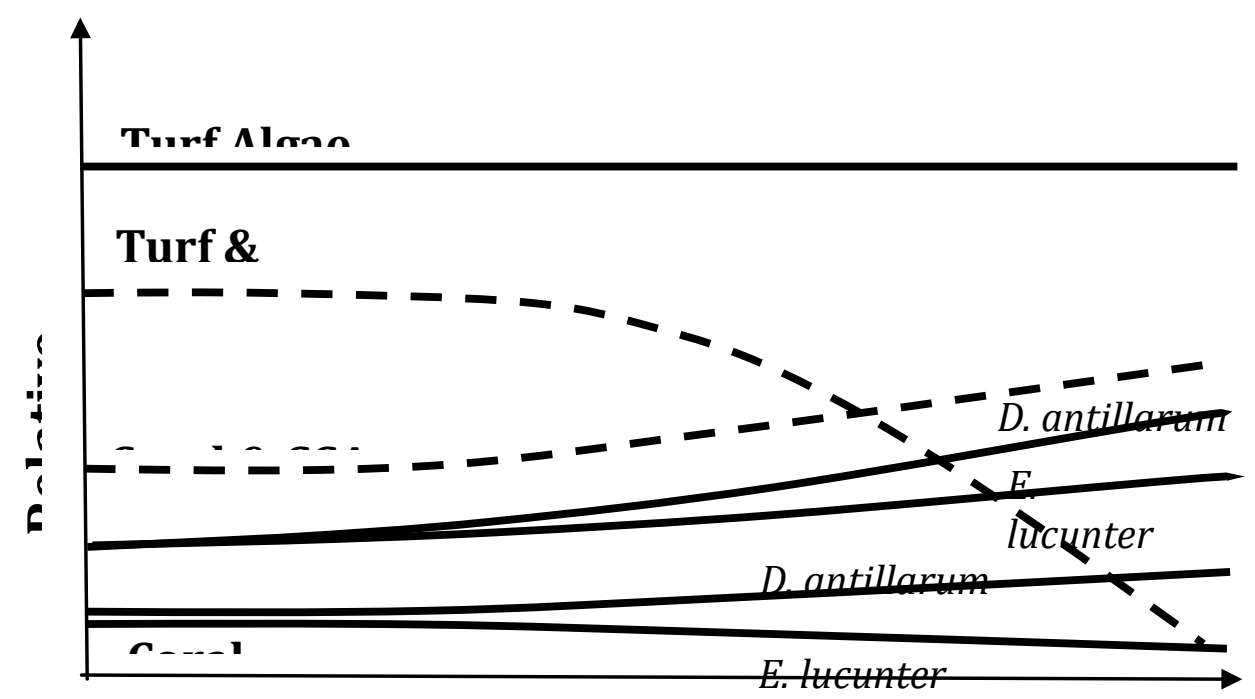

nrivor.

Figure 4: Grazer disturbance model for Akumal coral reef ecosystems. Dashed lines indicate the original model while solid lines indicate those results recorded during this survey. $(\mathrm{CCA}=$ crustose coralline algae $)$ 
An additional aspect to this study is that crustose coralline algae (CCA) as a coral settlement cue was significantly higher on the forereef sites where significantly more Echinometra lucunter occurred but this herbivore correlated negatively with coral cvoer. This echinoid species may have a further detrimental impact coral recovery not considered during other studies on echinoid dynamics. E. lucunter is not always present on other coral reefs and its relative E. viridis has been reported as a facilitator to coral recruitment. In the case of echinoids on Akumal reefs, their grazing behavior has not altered the dominance of a macroalgae state that is predicted under conditions of high nutrient availability.

In Chapter V I monitored macroalgae generic diversity, richness and evenness as well as considered factors such as nutrient availability over four years to determine if these measures varied temporally within an impacted, macroalgal-dominated ecosystem. These studies were done because measures of taxa richness, diversity and evenness are important to the overall structure of an ecosystem and when they are considered in conjunction with benthic functional groups examined in Chapter IV, a more integrated picture of ecosystem state can be established. Variability in macroalgae nitrogen and phosphorus concentrations precluded many determinations of significant trends, although nutrient content of Halimeda, the only genera present at multiple sites over time, did signify an increase in nutrients over time. Macroalgae nutrient data variability emphasizes the importance of continued studies on the effects of morphological differences between genera and the overall impact on these differences on nutrient uptake and assimilation. While I hypothesized that high nutrient availability would shift the ecosystem to one dominated by a single genera and therefore decrease diversity, richness 
and evenness, generic diversity and evenness actually increased at three of four sites throughout the study duration. South Forereef, the site which experienced a decrease in diversity, was also the site which experienced a significant increase in crustose coralline algae during Chapter IV therefore this benthic cover may have an important role in overall coral reef macroalgal diversity. The population of echinoid herbivores monitored during Chapter IV may also have a role in macroalgal diversity and further manipulations of these parameters would be beneficial to data interpretation. As Akumal reefs are turfalgal-sediment dominated and macroalgae generic diversity has increased at the majority of sites, a recovery to the formerly coral dominated state does not seem a realistic expectation of this ecosystem.

Results from the research produced during these studies provide answers to not only ecological questions but also important information to be utilized in marine park managers' quest to protect these important ecosystems. In considering those bottom-up forces controlling dominant benthic assemblages, active bioassay techniques in both seagrass and coral reef ecosystems can provide important information on the availability of nutrients to these environments. Protecting the sea turtle population from anthropogenic stresses (e.g. harvesting and nest disturbance) may be an appropriate goal for Akumal Bay marine park managers as these herbivores seem to play an important role in the health of the seagrass beds. Compounding factors such as coral diseases, overfishing and eutrophication may have driven the coral reef community in Akumal Bay to such an algal-dominated state that even the recovery of an important echinoid herbivore cannot assist in the return of a coral dominated state. This same conclusion may be drawn from the increased macroalgae generic diversity, richness and nutrient 
content as well. Protecting the coral reef habitat from further degradation could be the only conservation option left for this important resource. With increased impacts to coastal ecosystems through enrichment and overfishing, the response in primary producers reported during these surveys is a key indicator of the larger issues affecting the stability of the seagrass and coral habitats in Akumal Bay, Quintana Roo, Mexico. 


\section{REFERENCES}

Airoldi L (1998) Roles of disturbance, sediment stress, and substratum retention on spatial dominance in algal turf. Ecology 79:2759-2770

Airoldi L, Virgilio M (1998) Responses of turf-forming algae to spatial variations in the deposition of sediments. Marine Ecology Progress Series 165:271-282

Andersen T, Carstensen J, Hernandez-Garcia E, Duarte CM (2008) Ecological thresholds and regime shifts: Approaches to identification. Trends in Ecology and Evolution 24:4957

Aragones LV, Lawler IR, Foley WJ, Marsh H (2006) Dugong grazing and turtle cropping: Grazing optimization in tropical seagrass systems? Oecologia 149:635-647

Armitage AR, Fourqurean JW (2006) The short-term influence of herbivory near patch reefs varies between seagrass species. Journal of Experimental Marine Biology and Ecology 339:65-74

Armitage AR, Frankovich TA, Fourqurean JW (2011) Long-term effects of adding nutrients to an oligotrophic coastal environment. Ecosystems 14:430-444

Aronson RB, Edmunds PJ, Precht WF, Swanson DW, Levitan DR (1994) Large-scale, long-term monitoring of Caribbean coral reefs: Simple, quick, inexpensive technique. Atoll Research Bulletin 421:1-19

Aronson RB, MacIntyre IG, Wafnick CM, O'Neill MW (2004) Phase shifts, alternative states, and the unprecedented convergence of the two reef systems. Ecology 85:18761891

Aronson RB, Precht WF (2001) White-band disease and the changing face of Caribbean coral reefs. Hydrobiologia 460:25-38

Aronson RB, Precht WF (2006) Conservation, precaution, and Caribbean reefs. Coral Reefs 25:441-450

Atkinson MJ, Smith SV (1983) C:N:P ratios of benthic marine plants. Limnology and Oceanography 28:568-574

Bak RPM (1985) Recruitment patterns and mass mortalities in the sea urchin Diadema antillarum. Proceedings of the 5th International Coral Reef Congress 5:267-272

Baker DM, Jordan-Dahlgren E, Maldonado MA, Harvell CD (2010) Sea fan corals provide a stable isotope baseline for assessing sewage pollution in the Mexican Caribbean. Limnology and Oceanography 55:2139-2149 
Baker DM, MacAvoy SE, Kim K (2007) Relationship between water quality, deltaN and aspergillosis of Caribbean sea fan corals. Marine Ecology Progress Series 343:123-130

Bellwood DR, Fulton CJ (2008) Sediment-mediated suppression of herbivory on coral reefs: Decreasing resilience to rising sea levels and climate change? Limnology and Oceanography 53:2695-2701

Bellwood DR, Hughes TP, Folke C, Nystrom M (2004) Confronting the coral reef crisis. Nature 429:827-833

Biao X, Zhuhong D, Xiaoron W (2004) Impact of the intensive shrimp farming on the water quality of the adjacent coastal creeks from Eastern China. Marine Pollution Bulletin 48:543-553

Birch PB, Gordon DM, McComb AJ (1981) Nitrogen and phosphorus nutrition of Cladophora in the Peel-Harvey estuarine system, western Australia. Botanica Marina 24:381-387

Bjorndal KA (1980) Nutrition and grazing behavior of the green turtle Chelonia mydas. Marine Biology 56:147-154

Bjorndal KA (1997) Foraging ecology and nutrition of sea turtles. In: Lutz PL, Musick JA (eds) The biology of sea turtles. CRC Press, Boca Raton, FL, p 432

Bohnsack JA, Harper DE (1988) Length-weight relationships of selected marine reef fishes from southeastern United States and the Caribbean, Miami, Florida

Borum J (1985) Development of epiphytic communities on eelgrass (Zostera marina) along a nutrient gradient in a Danish estuary. Marine Biology 87:211-218

Bracken MES, Nielsen KJ (2004) Diversity of intertidal macroalgae increases with nitrogen loading by invertebrates. Ecology 85:2828-2836

Brown JS (1988) Patch use as an indicator of habitat preference, predation risk, and competition. Behavioral Ecology and Sociobiology 22:37-47

Bruno JF, Boyer KE, Duffy JE, Lee SC, Kertesz JS (2005) Effects of macroalgal species identity and richness on primary production in benthic marine communities. Ecology Letters 8:1165-1174

Bruno JF, Lee SC, Kertesz JS, Carpenter RC, Long ZT, Duffy JE (2006) Partitioning the effects of algal species identity and richness on benthic marine primary production.

OIKOS 115:170-178 
Burford MA, Costanzo SD, Dennison WC, Jackson CJand others (2003) A synthesis of dominant ecological processes in intensive shrimp ponds and adjacent coastal environments in NE Australia. Marine Pollution Bulletin 46:1456-1469

Campbell JE, Yarbro LA, Fourqurean JW (2012) Negative relationships between the nutrient and carbohydrate content of the seagrass Thalassia testudinum. Aquatic Botany 99:56-60

Carpenter RC (1986) Partitioning herbivory and its effects on coral reef algal communities. Ecological Monographs 56:345-363

Carpenter RC (1988) Mass mortality of a Caribbean sea urchin: Immediate effects on community metabolism and other herbivores. Proceedings of the National Academy of Sciences 85:511-514

Carpenter RC (2005) Sea urchin mass-mortality: Effects on reef algal abundance, species composition, and metabolism and other coral reef herbivores. NOAA:53-60

Carpenter RC, Edmunds PJ (2006) Local and regional scale recovery of Diadema promotes recruitment of scleractinian corals. Ecology Letters 9:271-280

Carruthers TJB, van Tussenbroek BI, Dennison WC (2005) Influence of submarine springs and wastewater on nutrient dynamics of Caribbean seagrass meadows. Estuarine and Coastal Shelf Science 64:191-199

Cheal AJ, Aaron MacNeil M, Cripps E, Emslie MJ, Jonker M, Schaffelke B, Sweatman $\mathrm{H}$ (2010) Coral-macroalgal phase shifts or reef resilience: Links with diversity and functional roles of herbivorous fishes on the great barrier reef. Coral Reefs 29:1005-1015

Chiappone M, Swanson DW, Miller SL (2002) Density, spatial distribution and size structure of sea urchins in Florida Keys coral reef and hard-bottom habitats. Marine Ecology Progress Series 235:117-126

Clarke KR, Warwick RM (2001) Change in marine communities: An approach to statistical anlaysis and interpretation, Vol. PRIMER-E Ltd, Plymouth

Clemente S, Hernandez JC, Rodriguea A, Brito A (2010) Identifying keystone predators and the importance of preserving functional diversity in sublittoral rocky-bottom areas. Marine Ecology Progress Series 413:55-67

Clemente S, Hernandez JC, Toledo K, Brito A (2007) Predation upon Diadema aff. Antillarum in barren grounds in the Canary Islands. Scientia Marina 71:745-754

Cloern JE (2001) Our evoloving conceptual model of the coastal eutrophication problem. Marine Ecology Progress Series 210:223-253 
Cohen R, Fong P (2005) Experimental evidence supports the use of d15n content of the opportunistic green macroalga Enteromorpha intestinalis (Chlorophyta) to determine nitrogen sources to estuaries. Journal of Phycology 41:287-293

Collado-Vides L, Ortegon-Anznar I, Granados AS, Comba-Barrera L, GonzalezGonzalez J (1998) Macroalgae of Puerto Morelos reef system, Mexican Caribbean. Hidrobiologica 8:133-143

Collie JS, Richardson K, Steele JH (2004) Regime shifts: Can ecological theory illuminate the mechanisms? Progress in Oceanography 60:281-302

Connell JH (1978) Diversity in tropical rain forests and coral reefs. Science 199:13021310

Connell JH, Slatyer RO (1977) Mechanisms of succession in natural communities and their role in community stability and organization. The American Naturalist 111:11191144

Costanza R, k'Arge R, de Groot R, Farber Sand others (1997) The value of the world's ecosystem services and natural capital. Nature 387:253-260

Costanzo SD, O'Donohue MJ, Dennison WC (2000) Gracilaria edulis (Rhodophyta) as a biological indicator of pulsed nutreints in oligotrophic waters. Journal of Phycology 36:680-685

Costanzo SD, O'Donohue MJ, Dennison WC, Loneragan NR, Thomas M (2001) A new approach for detecting and mapping sewage impacts. Marine Pollution Bulletin 42:149156

Costanzo SD, Udy J, Longstaff B, Jones A (2005) Using nitrogen stable isotope ratios of macroalgae to determine the effectiveness of sewage upgrades: Changes in the extent of sewage plumes over four years in Moreton Bay, Australia. Marine Pollution Bulletin $51: 212-217$

Dailer ML, Knox RS, Smith JE, Napier M, Smith CM (2010) Using d15N values in algal tissue to map locations and potential sources of anthropogenic nutrient inputs on the island of Maui, Hawai'i, USA. Marine Pollution Bulletin 60:655-671

de Ruyter van Steveninck ED, Bak RPM (1986) Changes in abundance of coral-reef bottom components related to mass mortality of the sea urchin Diadema antillarum. Marine Ecology Progress Series 34:87-94

Demes KW, Littler MM, Littler DS (2010) Comparative phosphate acquisition in giantcelled rhizophytic algae (Bryopsidales, Chlorophyta): Fleshy vs. calcified forms. Aquatic Botany 92:157-160 
deYoung B, Barange M, Beaugrand G, Harris R, Perry RI, Scheffer M, Werner F (2008) Regime shifts in marine ecosystems: Detection, prediction and management. Trends in Ecology and Evolution 23:402-409

Diaz-Pulido G, McCook LJ (2005) Effects of nutrient enhancement on the fecundity of a coral reef macroalga. Journal of Experimental Marine Biology and Ecology 317:13-24

Doering PH, Oviatt CA, Nowicki BL, Kos Eg, Reed LW (1995) Phosphorous and nitrogen limitation of primary production in a simulated estuarine gradient. Marine Ecology Progress Series 124:271-287

Duarte CM (1992) Nutrient concentration of aquatic plants: Patterns across species. Limnology and Oceanography 37:882-889

Duarte CM (1995) Submerged aquatic vegetation in relation to different nutrient regimes. Ophelia 41:87-112

Eckert GL (1998) Larval development, growth and morphology of the sea urchin Diadema antillarum. Bulletin of Marine Science 63:443-451

Edmunds PJ, Carpenter RC (2001) Recovery of Diadema antillarum reduces macroalgal cover and increases abundance of juvenile corals on a Caribbean reef. Proceedings of National Academy of Science 98:5067-5071

Ferreira SM, Brandao A, Baeta A, Neto JM, Lillebo AI, Jensen KT, Pardal MA (2007) Effects of restoration management on the estuarine isopod Cyathura carinata: Mediation by trematodes and habitat change. Marine Biology 151:109-118

Fong P, Boyer KE, Kamer K, Boyle KA (2003) Influence of initial tissue nutrient status of tropical marine algae on repsonse to nitrogen and phosphorus additions. Marine Ecology Progress Series 262:111-123

Fong P, Boyer KE, Zedler JB (1998) Developing an indicator of nutrient enrichment in coastal estuaries and lagoons using tissue nitrogen content of the opportunistic alga, Enteromorpha intestinalis (L. Link). Journal of Experimental Marine Biology and Ecology 231:63-79

Fong P, Fong JJ, Fong CR (2004) Growth, nutrient storage, and release of dissolved organic nitrogen by Enteromorpha intestinalis in response to pulses of nitrogen and phosphorus. Aquatic Botany 78:83-95

Fong P, Kamer K, Boyer KE, Boyle KA (2001) Nutrient content of macroalgae with differing morphologies may indicate sources of nutrients for tropical marine systems. Marine Ecology Progress Series 220:137-152 
Fourqurean JW, Manuel S, Coates KA, Kenworthy WJ, Smith SR (2010) Effects of excluding sea turtle herbivores from a seagrass bed: Overgrazing may have led to loss of seagrass meadows in bermuda. Marine Ecology Progress Series 419:223-232

Fourqurean JW, Moore TO, Fry B, Hollibaugh JT (1997) Spatial and temporal variation in C:N:P ratios, $\mathrm{d} 15 \mathrm{~N}$ and $\mathrm{d} 13 \mathrm{C}$ of eelgrass Zostera marina as indicators of ecosystem processes, Tomales Bay, California, USA. Marine Ecology Progress Series 157:147-157

Fourqurean JW, Powell GVN, Kenworthy WJ, Zieman JC (1995) The effects of longterm manipulation of nutrient supply on competition between the seagrasses Thalassia testudinum and Halodule wrightii in Florida Bay. Oikos 72:349-358

Fourqurean JW, Robblee MB (1999) Florida Bay--a history of recent ecological changes. Estuaries 22:345-357

Fourqurean JW, Willsie AW, Rose CD, Rutten LM (2001) Spatial and temporal pattern in seagrass community composition and productivity in South Florida. Marine Biology $138: 341-354$

Gaines SD, Lubchenco J (1982) A unified approach to marine plant-herbivore interactions. II. Biogeography. Annual Review of Ecological Systematics 13:111-138

Garcia-Salgado M, Nava-Martinez G, Bood N, McField Mand others (2008) Status of coral reefs in the Mesoamerican region. Status of Coral Reefs of the World: 2008:253264

Gerloff GC, Krombholz PH (1966) Tissue analysis as a measure of nutrient availability for the growth of angiosperm aquatic plants. Limnology and Oceanography 11:529-537

Ginsburg RN, Lowenstam HA (1958) The influence of marine bottom communities on depositional environment of sediments. Journal of Geology 66:310-318

Gordon DM, Birch PB, McComb AJ (1981) Effects of inorganic phosphorus and nitrogen on the growth of an estuarine Cladophora in culture. Botanica Marina 24:93-106

Grime JP (1973a) Competitive exclusion in herbaceous vegetation. Nature 242:344-347

Grime JP (1973b) Control of species density in herbaceous vegetation. Journal of Environmental Managment 1:151-167

Grime JP (1977) Evidence for the existence of three primary strategies in plants and its relevance to ecological and evolutionary theory. The American Naturalist 111:1169-1194 
Grunbaum H, Bergman G, Abbott DP, Ogden JC (1978) Intraspecific agonistic behavior in the rock-boring sea urchin Echinometra lucunter (L.) (Echinodermata: Echinoidea). Bulletin of Marine Science 28:181-188

Gunderson LH (2001) Managing surprising ecosystems in southern Florida. Ecological Economics 37:371-378

Halpern BS, Walbridge S, Selkoe KA, Kappel CVand others (2008) A global map of human impact on marine ecosystems. Science 319

Harvell D, Jordan-Dahlgren E, Merkel S, Rosenberg Eand others (2007) Coral diseases, environment drivers, and the balance between coral and microbial associates.

Oceanography 20:172-195

Hay ME (1981) The funcitonal morphology of turf-forming seaweeds: Persistence in stressful marine habitats. Ecology 62:739-750

Heaton THE (1986) Isotopic studies of nitrogen pollution in the hydrosphere and atmosphere: A review. Chemical Geology 58:87-102

Heck J, K.L., Valentine JF (2006) Plant-herbivore interactions in seagrass meadows. Journal of Experimental Marine Biology and Ecology 330:420-436

Heck J, Valentine JF (2007) The H.T. Odum synthesis essay: The primacy of top-down effects in shallow benthic ecosystems. Esutaries and Coasts 30:371-381

Hereu B, Zabala M, Linares C, Sala E (2005) The effects of predator abundance and habitat structural complexity on survival of juvenile sea urchins. Marine Biology 146:293-299

Hernandez JC, Clemente S, Sangil C, Brito A (2008) The key role of the sea urchin Diadema aff. Antillarum in controlling macroalgae assemblages throughout the Canary Islands (eastern subtropical Atlantic): An spatio-temporal approach. Marine Environmental Research 66:259-270

Hoey AS, Bellwood DR (2011) Suppression of herbivory by macroalgal density: A critical feedback on coral reefs? Ecology Letters 14:267-273

Horrocks JL, Stewart GR, Dennison WC (1995) Tissue nutrient content of Gracilaria spp (Rhodophyta) and water quality along an estuarine gradient. Marine and Freshwater Research 46:975-983

Hughes TP (1994) Catastrophes, phase shifts, and large-scale degradation of a Caribbean reef. Science 265:1547-1551 
Hughes TP, Baird AH, Bellwood DR, Card Mand others (2003) Climate change, human impacts, and the resilience of coral reefs. Science 301:929-933

Huston MA (1979) A general hypothesis of species diversity. American Naturalist 113:81-101

Idjadi JA, Haring RN, Precht WF (2010) Recovery of the sea urchin Diadema antillarum promotes scleractinian coral growth and survivorship on shallow Jamaican reefs. Marine Ecology Progress Series 403:91-100

Idjadi JA, Lee SC, Bruno JF, Precht WF, Allen-Requa L, Edmunds PJ (2006) Rapid phase-shift reversal on a Jamaican coral reefs. Coral Reefs 25:209-211

Jordan-Garza AG, Maldonado MA, Baker DM (2008) High abundance of Diadema antillarum on a Mexican reef. Coral Reefs 27:295

Keats DW, Knight MA, Pueschel CM (1997) Antifouling effects of epithallial shedding in three crustose coralline algae (rhodophyta, coralinales) on a coral reef. Journal of Experimental Marine Biology and Ecology 213:281-293

Knowlton N (1992) Thresholds and multiple stable states in coral-reef community dynamics. American Zoologist 32:674-682

Konar B, Iken K (2009) Influence of taxonomic resolution and morphological functional groups in multivariate analyses of macroalgal assemblages. Phycologia 48:24-31

Kuiper-Linley M, Johnson CR, Lanyon JM (2007) Effects of simulated green turtle regrazing on seagrass abundance, growth and nutritional status of Moreton Bay, southeast Queensland, Australia. Marine and Freshwater Research 58:492-503

Lal A, Arthur R, Marba N, Lill AWT, Alcoverro T (2010) Implications of conserving an ecosystem modifier: Increasing green turtle (Chelonia mydas) densities substantially alters seagrass meadows. Biological Conservation 143:2730-2738

Lapointe BE (1997) Nutrient thresholds for bottom-up control of macroalgal blooms on coral reefs in Jamaica and Southeast Florida. Limnology and Oceanography 42:11191131

Lapointe BE (1999) Simultaneous top-down and bottom-up forces control macroalgal blooms on coral reefs (reply to the comment by Hughes et al.). Limnology and Oceanography 44:1586-1592

Lapointe BE, Barile PJ, Matzie WR (2004) Anthropogenic nutrient enrichment of seagrass and coral reef communities in the lower Florida Keys: Discrimination of local 
versus regional nitrogen sources. Journal of Experimental Marine Biology and Ecology $308: 23-58$

Lapointe BE, Littler MM, Littler DS (1992) Nutrient availabiilty to marine macroalgae in siliclastic versus carbonate-rich coastal waters. Estuaries 15:75-82

Lapointe BE, Tenore KR (1981) Experimental oudoor studies with Ulva fasciata delile. I. Interactions of light and nitrogen on nutrient uptake, growth, and biochemical composition. Journal of Experimental Marine Biology and Ecology 53:135-152

Lee KS, Dunton KH (1997) Effects of in situ light reduction on the maintenance, growth and partitioning of carbon resources in Thalassia testudinum Banks ex Konig. Journal of Experimental Marine Biology and Ecology 210:53-73

Lee SC (2006) Habitat complexity and consumer-mediated positive feedbacks on a caribbean coral reef. OIKOS 112:442-447

Leichter JJ, Stewart HL, Miller SL (2003) Episodic nutrient transport to Florida coral reefs. Limnology and Oceanography 48:1394-1407

Lessios HA (1995) Diadema antillarum 10 years after mass mortality: Still rare, despite help from a competitor. Proceedings of the Royal Society of London 259:331-337

Lessios HA (2005) Diadema antillarum populations in Panama twenty years following mass mortality. Coral Reefs 24:125-127

Lessios HA, Cubit JD, Robertson DR, Shulman MJ, Parker MR, Garrity SD, Levings SC (1984a) Mass mortality of Diadema antillarum on the Caribbean coast of Panama. Coral Reefs 3:173-182

Lessios HA, Robertson DR, Cubit JD (1984b) Spread of Diadema mass mortalities through the Caribbean. Science 226:335-337

Levitan DR (1991) Influence of body size and population density on fertilization success and reproductive output in a free-spawning invertebrate. Biological Bulletin 181:261-268

Levitan DR (1995) The ecology of fertilization in free-spawning invertebrates, Vol. CRC Press, NY

Levitan DR, Genovese SJ (1989) Substratum-dependent predator-prey dynamics: Patch reefs as refuges from gastropod predation. Journal of Experimental Marine Biology and Ecology 130:111-118 
Lin DT, Fong P (2008) Macroalgal bioindicators (growth, tissue N, d15N) detect nutrient enrichment from shrimp farm effluent entering Opunohu Bay, Moorea, French Polynesia. Marine Pollution Bulletin 56:245-249

Littler MM, Littler DS (1980) The evolution of thallus form and survival strategies in benthic marine macroalgae: Field and laboratory tests of a functional form model. The American Naturalist 116:25-44

Littler MM, Littler DS (1984) A relative-dominance model for biotic sciences Proceedings of the Joint Meeting of the Atlantic Reef Committee Society of Reef Studies, Miami, Florida

Littler MM, Littler DS, Lapointe BE (1988) A comparison of nutrient- and light-limited photosynthesis in psammophytic versus epilithic forms of Halimeda (caulerpales, Halimedacea) from the Bahamas. Coral Reefs 6:219-225

Littler MM, Littler DS, Taylor PR (1983) Evolutionary strategies in a tropical barrier reef system: Functional-form groups of marine macroalgae. Journal of Phycology 19:229-237

Lubchenco J (1978) Plant species diversity in a marine intertidal community: Importance of herbivore food preference and algal competitive abilities. The American Naturalist 112:23-39

Lyngby JE (1990) Monitoring of nutrient availability and limitation using the marine macroalgae Ceramium rubrum. Aquatic Botany 38:153-161

Macia S (2000) The effects of sea urchin grazing and drift algal blooms on a subtropical seagrass bed community. Journal of Experimental Marine Biology and Ecology 246:5367

Macia S, Robinson MP, Nalevanko A (2007) Experimental dispersal of recovering Diadema antillarum increases grazing intensity and reduces macroalgal abundance on a coral reef. Marine Ecology Progress Series 348:173-182

Marba N, Santiago R, Diaz-Almela E, Alvarez E, Duarte CM (2006) Seagrass (Posidonia oceanica) vertical growth as an early indicator of fish farm-derived stress. Estuarine, Coastal and Shelf Science 67:475-483

McClanahan TR (1999) Predation and the control of the sea urchin Echinometra viridis and fleshy algae in the patch reefs of Glovers Reef, Belize. Ecosystems 2:511-523

McCook LJ, Jompa J, Diaz-Pulido G (2001) Competiton between corals and algae on coral reefs: A review of evidence and mechanisms. Coral Reefs 19:400-417 
McGehee MA (1992) Distribution and abundance of two species of Echinometra (Echinoidea) on coral reefs near Puerto Rico. Caribbean Journal of Science 28:173-183

McGlathery KJ (1995) Nutrient and grazing influences on a subtropical seagrass community. Marine Ecology Progress Series 122:239-252

McManus JW, Polsenberg JF (2004) Coral-algal phase shifts on coral reefs: Ecological and environmental aspects. Progress in Oceanography 60:263-279

Metcalfe CD, Beddows PA, Bouchot GG, Metcalfe TL, Li H, Van Lavieren H (2011) Contaminants in the coastal karst aquifer system along the Caribbean coast of the Yucatan Peninsula, Mexico. Environmental Pollution 159:991-997

Miller MW, Kramer KL, Williams SM, Johnston L, Szmant AM (2009) Assessment of current rates of Diadema antillarum larval settlement. Coral Reefs 28:511-515

Mittelbach GG, Steiner CF, Scheiner SM, Gross KLand others (2001) What is the observed relationship between species richness and productivity? Ecology 82:2381-2396

Moran KL, Bjorndal KA (2005) Simulated green turtle grazing affects structure and productivity of seagrass pastures. Marine Ecology Progress Series 305:235-247

Moran KL, Bjorndal KA (2007) Simulated green turtle grazing affects nutrient composition of the seagrass Thalassia testudinum. Marine Biology 150:1083-1092

Morse DE, Hooker N, Morse ANC, Jensen RA (1988) Control of larval metamorphosis and recruitment in sympatric Agariciid corals. Journal of Experimental Marine Biology and Ecology 116:193-217

Mortimer JA (1981) The feeding ecology of the West Caribbean green turtle (Chelonia mydas) in Nicaragua. Biotropica 13:49-58

Mumby PJ, Hedley JD, Zychaluk K, Harborne AR, Blackwell PG (2006) Revisiting the catastrophic die-off of the urchin Diadema antillarum on caribbean coral reefs: Fresh insignts on resilience from a simulation model. Ecological Modelling 196:131-148

Mumby PJ, Steneck RS (2008) Coral reef management and conservation in light of rapidly evolving ecological paradigms. Trends in Ecology and Evolution 23:555-563

Murray G (2007) Constructing paradise: The impacts of big tourism in the Mexican coastal zone. Coastal Management 35:339-355

Mutchler T, Dunton KH, Townsend-Small A, Fredriksen S, Rasser MK (2007) Isotopic and elemental indicators of nutrient sources and status of coastal habitats in the 
Caribbean Sea, Yucatan Peninsula, Mexico. Estuarine, Coastal and Shelf Science 74:449457

Myhre S, Acevedo-Gutierrez A (2007) Recovery of sea urchin Diadema antillarum populations is correlated to increased coral and reduced macroalgal cover. Marine Ecology Progress Series 329:205-210

Neckles HA, Wetzel RL, Orth RJ (1993) Relative effects of nutrient enrichment and grazing on epiphyte-macrophyte (Zostera marina L.) dynamics. Oecologia 93:285-295

Nystrom M, Folke C, Molberg F (2000) Coral reef disturbance and resilience in a humandominated environment. Trends in Ecological Evolution 15:413-417

O'Leary JK, McClanahan TR (2010) Trophic cascades result in large-scale coralline algae loss through differential grazer effects. Ecology 91:3584-3597

Ogden JC (1976) Some aspects of herbivore-plant relationships on Caribbean reefs and seagrass beds. Aquatic Botany 2:103-116

Orth RJ, Carruthers TJB, Dennison WC, Duarte CMand others (2006) A global crisis for seagrass ecosystems. BioScience 56:987-996

Pacheco J, Marin L, Cabrera A, Steinich B, Escolero O (2001) Nitrate temporal and spatial patterns in 12 water-supply wells, Yucatan, Mexico. Environmental Geologist 40:708-715

Paddack MJ, Cowen RK, Sponaugle S (2006) Grazing pressure of herbivorous coral reef fishes on low coral-cover reefs. Coral Reefs 25:461-472

Paddack MJ, Reynolds JD, Aguilar C, Appeldoorn RS and others (2009) Recent regionwide declines in Caribbean reef fish abundance. Current Biology 19:1-6

Paine RT (1966a) Food web complexity and species diversity. The American Naturalist 100:65-75

Paine RT (1971) A short-term experimental investigation of resources partitioning in a New Zealand rocky intertidal habitat. Ecology 52:1096-1106

Pakulski JD, Benner R (1992) An improved method for the hydrolysis and MBTH analysis of dissolved and particulate carbohydrates in seawater. Marine Chemistry 40:143-160

Peterson BJ, Fry B (1987) Stable isotopes in ecosystem studies. Annual Review of Ecological Systematics 18:293-320 
Petraitis PS, Latham RE (1999) The importance of scale in testing the origins of alternative community states. Ecology 80:429

Randall JE, Schroeder RE, Starck II WA (1964) Notes on the biology of the echinoid Diadema antillarum. Caribbean Journal of Science 4:421-433

Redfield AC (1958) The biological control of chemical factors in the environment. The American Scientist 46:205-221

Roberts HHS, J.N. (1983) Wave-current interactions on a shallow reef (Nicaragua, Central America). Coral Reefs 1:209-214

Ruiz-Ramos DVH-D, E.A.; Schizas, N.V. (2011) Population status of the long-spined urchin Diadema antillarum in Puerto Rico 20 years after a mass mortality event. Bulletin of Marine Science 87:113-127

Sammarco PW (1980) Diadema and its relationship to coral spat mortality: Grazing, competition, and biological disturbance. Journal of Experimental Marine Biology and Ecology 45

Sandin SA, McNamara DE (2012) Spatial dynamics of benthic competition on coral reefs. Oecologia 168:1079-1090

Savage C, Elmgren R (2004) Macroalgal (Fucus vesiculosus) d15N values trace decrease in sewage influence. Ecological Applications 14:517-526

Scheffer M, Carpenter S, Foley JA, Folkes C, B.Walker (2001) Catastrophic shifts in ecosystems. Nature 413:591-596

Scheffer M, van Nes EH (2004) Mechanisms for marine regime shifts: Can I use lakes as microcosms for oceans? Progress in Oceanography 60:303-319

Schutte VGWS, E.R.; Bruno, J.F. (2010) Regional spatio-temporal trends in Caribbean coral reef benthic communities. Marine Ecology Progress Series 402:115-122

Scoffin TP (1970) The trapping and binding of subtidal carbonate sediments by marine vegetation in Bimini Lagoon, Bahamas. Journal of Sedimentary Petrology 40:249-273

Shulman MJ (1990) Aggression among sea urchins on Caribbean coral reefs. Journal of Experimental Marine Biology and Ecology 140:197-207

Sousa WP (1985) Disturbance and patch dyanmics on rocky intertidal shores. In: Pickett STA, White PS (eds) The ecology of natural disturbance and patch dynamics. Academic Press, San Diego, California, USA, p 101-124 
Stachowicz JJ, Bruno JF, Duffy JE (2007) Understanding the effects of marine biodiversity on communities and ecosystems. Annual Review of Ecological Systematics 38:739-766

Steneck RS (1983) Escalating herbivory and resulting adaptive trends in calcareous algal crusts. Paleobiology 9:44-61

Steneck RS (1997) Crustonse corallines, other algal functional groups, herbivore and sediments: Complex interactsion along reef productivity gradients. In: Lessios HA, Macintyre IG (eds) Proceedings of the Eighth International Coral Reef Symposium. Smithsonian Institute Press, Balboa, Panama, p 695-7000

Steneck RS, Dethier MN (1994) A functional group approach to the structure of algaldominated communities. OIKOS 69:476-498

Steneck RS, Lang JC (2003) Rapid assessment of Mexico's Yucatan Reef in 1997 and 1999: Pre- and post-mass bleaching and hurricane mitch

Stimson J, Larned S, Conklin E (2001) Effects of herbivory, nutrient levels, and introduced algae on the distribution and abundance of the invasive macroalga Dictyosphaeria cavernosa in Kaneohe Bay, Hawaii. Coral Reefs 19:343-357

Szmant AM (2002) Nutrient enrichment on coral reefs: Is it a major cause of coral reef decline? Estuaries 25:743-766

Thayer GW, Bjorndal KA, Ogden JC, Williams SL, Zieman JC (1984) Role of larger herbivores in seagrass communities. Estuaries 7:351-376

Thornber CS, DiMilla P, Nixon SW, McKinney RA (2008) Natural and anthropogenic nitrogen uptake of bloom-forming macroalgae. Marine Pollution Bulletin 56:261-269

Umezawa Y, Miyajima T, Yamamuro M, Kayanne H, Koike I (2002) Fine-scale mapping of land-derived nitrogen in coral reefs by d $15 \mathrm{~N}$ in macroalgae. Limnology and Oceanography 47:1405-1416

Valentine JF, Duffy JE (2006) The central role of grazing in seagrass ecology. In: Larkum T, Orth RJ, Duarte CM (eds) Seagrass: Biology, ecology and their conservation. Springer, p 463-501

Valentine JF, Heck J, K.L. (1999) Seagrass herbivory: Evidences for the continued grazing of marine grasses. Marine Ecology Progress Series 176:291-302

Valentine JF, Heck J, K.L., Kirsch KD, Webb D (2000) Role of sea urchin Lytechinus variegatus grazing in regulating subtropical turtlegrass Thalassia testudinum meadows in the Florida Keys (USA). Marine Ecology Progress Series 200:213-228 
Valentine JF, Heck KL, Busby J, Webb D (1997) Experimental evidence that herbivory can increase shoot density in a subtropical turtlegrass (Thalassia testudinum) meadow. Oecologia 112:193-200

Vitousek PM, Mooney HA, Lubchenco J, Melillo JM (1997) Human domination of earth's ecosystems. Science 277:494-499

Waite T, Mitchell R (1972) The effect of nutrient fertilization on the benthic alga Ulva lactuca. Botanica Marina 15:151-156

Wallentinus I (1984) Comparisons of nutrient uptake rates of Baltic macroalgae with different thallus morphologies. Marine Biology 80:215-225

Warwick RM (1988a) Analysis of community attributes of the macrobenthos of Frierfjord/Langesundfjord at taxonomic levels higher than species. Marine Ecology Progress Series 46:167-170

Warwick RM (1988b) The level of taxonomic discrimination required to detect pollution effects on marine benthic communities. Marine Pollution Bulletin 19:259-268

Waycott M, Duarte CM, Carruthers TJB, Orth RJand others (2009) Accelerating loss of seagrass across the globe threatens coastal ecosystems. Proceedings of the National Academy of Sciences 106:12377-12381

Wefer G (1980) Carbonate production by algae Halimeda, Penicillus and Padina. Nature 285:323-324

Williams AH (1981) An analysis of competitive interactions in a patchy back-reef environment. Ecology 62:1107-1120

Williams SL (1988) Thalassia testudinum productivity and grazing by green turtles in a highly disturbed seagrass bed. Marine Biology 98:447-455

Williams SM, Yoshioka PM, Garcia Sais JR (2010) Recruitment pattern of Diadema antillarum in La Parguera, Puerto Rico. Coral Reefs 29:809-812

Worm B, Lotze HK, Heillebrand H, Sommer U (2002) Consumer versus resource control of species diversity and ecosystem functioning. Nature 417:848-851

Yachi S, Loreau M (1999) Biodiversity and ecosystem productivity in a fluctuating environment: The insurance hypothesis. Proceedings of the National Academy of Sciences 96:1463

Zieman JC (1974) Methods for the study of the growth and production of turtle grass, Thalassia testudinum Konig. Aquaculture 4:139-143 
Zieman JC, Iverson RL, Ogden JC (1984) Herbivory effects on Thalassia testudinum leaf growth and nitrogen content. Marine Ecology Progress Series 15:151-158 
VITA

ELIZABETH ANNE LACEY

Born, Cincinnati, Ohio

2000-2003

B.S., Biology

University of North Carolina at Wilmington

Wilmington, North Carolina

2004-2006

M.S., Biology

Nova Southeastern University

Fort Lauderdale, Florida 